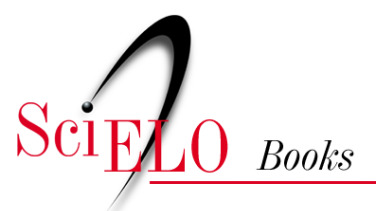

\title{
A ironia e suas refrações \\ um estudo sobre a dissonância na paródia e no riso
}

Camila da Silva Alavarce

ALAVARCE, CS. A ironia e suas refrações: um estudo sobre a dissonância na paródia e no riso [online]. São Paulo: Editora UNESP; São Paulo: Cultura Acadêmica, 2009. 208 p. ISBN 978-857983-025-9. Available from SciELO Books <http://books.scielo.org>.

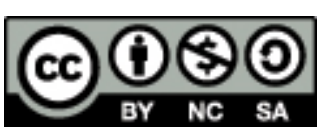

All the contents of this chapter, except where otherwise noted, is licensed under a Creative Commons Attribution-Non Commercial-ShareAlike 3.0 Unported.

Todo o conteúdo deste capítulo, exceto quando houver ressalva, é publicado sob a licença Creative Commons Atribuição Uso Não Comercial - Partilha nos Mesmos Termos 3.0 Não adaptada.

Todo el contenido de este capítulo, excepto donde se indique lo contrario, está bajo licencia de la licencia Creative Commons Reconocimento-NoComercial-CompartirIgual 3.0 Unported. 
A IRONIA E SUAS REFRAÇÕES

UMESTUDO

SOBRE A DISSONÂNCIA

NA PARÓDIA E NO RISO

CAMILA DA SILVAALAVARCE 
A IRONIA E SUAS REFRAÇÕES 



\title{
CAMILA DA SILVA ALAVARCE
}

\author{
A IRONIA \\ E SUAS REFRAÇÕES \\ UM ESTUDO \\ SOBRE A DISSONÂNCIA \\ NA PARÓDIA E NO RISO
}




\section{() 2009 Editora UNESP}

\section{Cultura Acadêmica}

Praça da Sé, 108

01001-900 - São Paulo - SP

Tel.: $(0 \times x 11)$ 3242-7171

Fax: (0xx1 1) 3242-7172

www.editoraunesp.com.br

feu@editora.unesp.br

CIP- Brasil. Catalogação na fonte

Sindicato Nacional dos Editores de Livros, RJ

A281i

Alavarce, Camila da Silva

A ironia e suas refrações : um estudo sobre a dissonância na paródia e no riso / Camila da Silva Alavarce. - São Paulo : Cultura Acadêmica, 2009.

208p.

Inclui bibliografia

ISBN 978-85-7983-025-9

1. Ironia na literatura. 2. Paródia. 3. Riso. 4. Leitores - Reação crítica. 5. Literatura - História e crítica. I. Título.

09-6223

CDD: 809

CDU: 82.09

Este livro é publicado pelo Programa de Publicações Digitais da Pró-Reitoria de Pós-Graduação da Universidade Estadual Paulista "Júlio de Mesquita Filho" (UNESP)

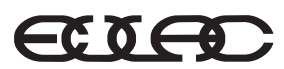

Asociación de Editoriales Universitarias de América Latina y el Caribe

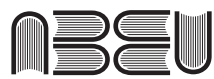

Associação Brasileira de Editoras Universitárias 
Ao João, companheiro inseparável, amigo e amoroso.

Ao apoio que me ofertou tanto nos momentos de trabalho como na hora do descanso, quando seu sorriso e suas brincadeiras dissipavam todo o cansaço. Ao amor...

À família inteira e, em especial, a meus pais, Laci e Augusto, pela vida. E a meus irmãos Fábio e Alex. Às presenças amigas, tão queridas, que passeiam de modo significativo por minha existência. Aos que aprenderam a amar. 

A alma humana é uma caixa donde sempre pode saltar um palhaço a fazer caretas e a deitar-nos a língua de fora, mas há ocasiões em que esse mesmo palhaço se limita a olhar-nos por cima da borda da caixa, e se vê que, por acidente, estamos procedendo segundo o que é justo e honesto, acena aprovadoramente com a cabeça e desaparece a pensar que ainda não somos um caso perdido.

José Saramago, 2002, p.293 



\section{SUMÁRIO}

Introdução 11

1. A valorização do elemento dual e o papel do leitor 15

2. Ironia 23

3. Paródia 57

4. O riso 71

5. Conclusão teórica 115

6. Dissonâncias literárias 143

Considerações finais 193

Referências bibliográficas 197 



\section{INTRODUÇÃO}

A criação literária traz como condição necessária uma carga de liberdade que a torna independente sob muitos aspectos, de tal maneira que a explicação dos seus produtos é encontrada sobretudo neles mesmos. Como conjuntos de obras de arte a literatura se caracteriza por essa liberdade extraordinária que transcende as nossas servidões.

Antonio Candido

Este livro almeja o estudo dos discursos caracterizados pela ambiguidade, mais especificamente, a ironia, a paródia e o riso. Como qualquer ato de comunicação, tais discursos propõem sempre um ponto de vista. Assim, seja de um modo mais impositivo, seja de um mais liberal, a ironia, a paródia e o riso veiculam suas "verdades”, mas não o fazem de forma explícita. As opiniões sugeridas por tais modalidades caracterizam-se por serem resultado de uma tensão inerente a esses discursos.

Nesse sentido, existe um embate de vozes dissonantes na estrutura da ironia, da paródia e, ainda, do riso, entendido na presente investigação como fruto de uma incongruência entre o "pensado" e a "realidade concreta". Para compreender a mensagem ou as ideias veiculadas por essas modalidades de discurso, o sujeito deve perce- 
ber a existência de vozes que se chocam na estrutura desses textos. Essa é, indubitavelmente, a condição fundamental para a concretização da ironia, da paródia e do riso. Sem a participação do sujeito na construção do sentido, essas categorias não existem - pelo menos não enquanto "ironia", "paródia" e "riso".

Logo, à medida que convidam o sujeito para colaborar na construção do sentido, esses discursos são vias para instaurar um movimento de reflexão e, consequentemente, de ampliação do conhecimento e da percepção crítica. As categorias que motivam a presente pesquisa são, pois, exigentes, já que convocam o sujeito, valorizando-o como um ser capaz de assimilar a estrutura contraditória desses discursos por meio do exercício da razão. É realmente significativa a possibilidade de esses discursos alargarem a visão de mundo do sujeito, permitindo que ele acesse outras realidades ou, ainda, que delineie sua própria forma de enxergar e entender a realidade (que pode destoar, e muito, do senso comum ou da concepção da maioria).

Nesse sentido, ao longo dos capítulos, realizamos a análise de cada uma dessas categorias separadamente, e, depois, estudamos as relações entre elas. Vale salientar que, no presente trabalho, a ironia é considerada como base para os acontecimentos da paródia e do riso.

A partir de então, procuramos localizar e examinar as semelhanças entre esses discursos e, ainda, as características específicas a cada um - para, mais à frente, canalizá-las como suporte para a análise de alguns textos literários (de autoria de Saramago, Calvino e Dostoievski, conforme detalhado mais adiante).

Acreditamos que a ironia, a paródia e o riso atuam, nos textos literários, na grande maioria de suas ocorrências, com o objetivo de suspender a censura e de burlar as prisões dos discursos monofônicos e consequentemente autoritários. Isso é possível porque as modalidades em questão privilegiam a polifonia e o elemento dissonante, legitimados pelo contraste de ideias, traço comum entre esses três tipos de discurso. Logo, essas categorias, como atos de comunicação, optam por determinada ótica ou postura, que entra em choque com outra, e é isso que garante a polifonia. 
Devido a essas tensões e embates, que exigem uma participação ativa do leitor, o presente trabalho parte do princípio de que o público receptor é elemento de importância decisiva, sobretudo quando estamos perante textos literários em cujo cerne há o embate de "vozes" contraditórias. Cabe, pois, ao leitor a tarefa de decodificar, na estrutura do texto em análise, os discursos dissonantes.

Graças a seu relevante papel, o leitor já aparece no primeiro capítulo deste livro. Nele, o receptor de textos marcados pela ironia, paródia ou riso é tratado como uma instância que de modo algum é passiva na recepção do texto literário, pois sua contribuição é fundamental para a construção do sentido. Ainda nesse capítulo, procuramos, em linhas gerais, mostrar o tipo de abordagem escolhida para a questão da duplicidade caracterizadora desses discursos, que, aliás, se configura como uma importante semelhança entre o riso, a paródia e a ironia.

Logo em seguida, no segundo capítulo, iniciamos um estudo pormenorizado da ironia, de suas funções e de suas variadas possibilidades de ocorrência. Procuramos aprofundar o mais possível o exame dessa modalidade, enfatizando a ideia (sobretudo na seção “A carga afetiva da ironia") de que a ironia é contraditória em todos os aspectos, já que se inicia da tensão entre discursos incongruentes e ainda produz, naqueles que se utilizam dela e principalmente em seus receptores, efeitos bastante contraditórios.

O capítulo 3 trata da paródia como um tipo de texto literário que se constitui, em primeiro lugar, pelo choque entre discursos dissonantes, como é o caso, num outro nível, da ironia. Almejamos, nesse capítulo, argumentar a favor da ideia de que o texto paródico não se caracteriza simplesmente como um tipo de discurso niilista ou desconstrucionista; ao contrário, procuramos apontar para sua importância como uma modalidade que permite a revisão crítica do passado histórico e literário, promovendo, inclusive, a perpetuação desse passado e de suas peculiaridades histórico-culturais.

O capítulo 4 traz uma reflexão acerca do riso, discutindo as proposições de diversos teóricos, de variadas disciplinas ou áreas de conhecimento (como filósofos, poetas, teóricos da literatura). Den- 
tro desse leque, privilegiamos especialmente (devido a sua afinidade com os propósitos de nossa pesquisa) as teorias do riso de Schopenhauer, Baudelaire e Jean Paul. Entre outros motivos, são teorias que proporcionam uma aproximação estrutural e filosófica entre o fenômeno do riso e os discursos irônicos e paródicos. Nesse sentido, o riso - como a ironia e a paródia - configura-se também como um tipo de discurso que instaura, ao invés da certeza, a possibilidade, em lugar do uníssono, o ambivalente, a tensão e o elemento instável.

No capítulo 5, são encontradas as inferências obtidas a partir do estudo da ironia, da paródia e do riso e, em razão disso, esse capítulo é uma espécie de conclusão teórica do presente trabalho. Nele estudamos os significativos pontos de contato entre a ironia, a paródia e o riso. Examinamos, ainda, questões fundamentais para nossa pesquisa, como a relevância do sujeito - que caracteriza as três modalidades -, as relações entre paródia e ironia romântica, o tipo de contraste que especifica a ironia, a paródia e o riso e, ainda, pensamos em uma aproximação entre nossas categorias de estudo e a problemática tão convidativa da mímesis.

O capítulo 6 traz um estudo de obras literárias, analisadas a partir da ironia, paródia e riso. Este trabalho contempla a análise de três textos: os romances $O$ homem duplicado (2002), de José Saramago, e $O$ cavaleiro inexistente (1959), de Ítalo Calvino, e o conto "O duplo" (1846), de Dostoievski. É importante deixar claro que a seleção das obras guiou-se pela estrutura dissonante dessas narrativas, em cujo bojo encontramos muitas e variadas aplicações estéticas da ironia, da paródia e do riso.

Mediante esse recorte específico (tanto no plano teórico quanto no estético) buscamos discutir alguns aspectos dessas categorias de linguagem extremamente complexas e fascinantes, além de refletir sobre as possibilidades fecundas de relação entre esses discursos. Esperando que nosso trabalho possa servir de contribuição e estímulo aos estudos literários neste campo específico, convidamos o leitor para nos acompanhar nessa jornada pelas sinuosas galerias e contundentes subterrâneos da ironia, da paródia e do riso. 


\section{1 \\ A VAlORIZAÇÃo do ElEMENTO DUAL E O PAPEL DO LEITOR}

A natureza ambígua, complexa e elaborada do discurso literário afirma-se, justamente, na medida em que, de múltiplas maneiras, sempre conseguiu burlar as prisões, o proibido, e toda impossibilidade concreta do mundo imediato.

Ângela Maria Dias

Inicialmente, é preciso levar em conta a certeza de que existem semelhanças bastante interessantes entre o riso, a paródia e a ironia. Essas modalidades são vizinhas e, como tal, têm em comum, quase sempre, a função de questionar um modelo maniqueísta, seja ele qual for. Resulta dessa característica um efeito de sentido bastante importante: a tensão ou o elemento dissonante.

Assim, as categorias riso, ironia e paródia atuam na suspensão da censura, contrariando, muitas vezes, uma ideologia que se diz séria e ocasionando, pois, discursos polifônicos e conflitantes. Isso posto, serão mostradas, a seguir, em linhas gerais, as semelhanças entre o riso, a ironia e a paródia; no capítulo 6, esses conceitos serão mais detalhados. Essa exposição inicial e pouco aprofundada é necessária para que se tenha uma ideia do raciocínio que se pretende desenvolver a respeito dessas modalidades. 
Começando pelo cômico, Ângela Maria Dias cita a visão de alguns estudiosos de renome sobre o riso. De acordo com ela, para Freud, o cômico consistiria no contraste entre ideias; ainda segundo Ângela Maria, Bergson apontou como causa organizadora do riso a circunstancial incapacidade humana de adaptação a situações novas; e, seguindo nessa mesma linha, a autora cita, ainda, Schopenhauer, que considera a percepção da incongruência entre o que se pensa e o que se vê como principal fator para a existência do riso (1981, p.38). De acordo com Ângela Maria Dias,

Salta aos olhos o caráter contraditório, ambíguo, incongruente do riso. Se fizermos uma análise dos discursos críticos em relação ao impulso cômico no homem constataremos com expressiva frequência a intensidade da referência ao dado ambivalente, duplo, conflitante, relativo à coexistência de feições opostas, no interior de uma mesma entidade. Por isso, talvez pudéssemos sugerir que a percepção da diferença, que o reconhecimento do plural, do turbulento, do desigual, implícitos numa espécie de instável conciliação, configuram o clima propício à instauração do humor. (1981, p.38)

Boris Schnaiderman, em seu artigo "Paródia e mundo do riso", cita algumas palavras dos teóricos e historiadores da literatura D. S. Likhatchóv e A. M. Pantchenko, inseridas na obra $O$ mundo do riso da Rússia antiga:

Exteriormente, em sua camada superficial, o riso deforma intencionalmente o mundo, faz experimentos com ele, priva o mundo de explicações racionais e ligações de causa e efeito, etc. Mas, destruindo, o riso, ao mesmo tempo constrói: ele cria o seu antimundo fantástico, que traz em si determinada concepção do universo, determinada relação com a realidade ambiente. Esta relação do riso com a realidade é variável nas diferentes épocas e em diferentes povos. (Apud Schnaiderman, 1980, p.90-1, grifos nossos)

É imprescindível perceber que o traço ambíguo, dissonante, duplo, plural, desigual, entre tantos outros adjetivos sinônimos ca- 
racterizadores do humor, se faz também presente nos discursos irônicos e, ainda, na paródia. Em relação à ironia, a estudiosa Lélia Parreira Duarte tem uma definição bastante esclarecedora:

Nada pode ser considerado irônico se não for proposto e visto como tal; não há ironia sem ironista, sendo este aquele que percebe dualidades ou múltiplas possibilidades de sentido e as explora em enunciados irônicos, cujo propósito somente se completa no efeito correspondente, isto é, numa recepção que perceba a duplicidade de sentido e a inversão ou a diferença existente entre a mensagem enviada e a pretendida. (1994, p.55, grifos nossos)

A ambiguidade é, também, propriedade da ironia, que deve ser entendida - em seu modo mais frequente de manifestação - como a figura retórica por meio da qual "se diz o contrário do que se diz"; em outras palavras, pode-se afirmar, sobre esse tipo de ironia, que se trata de um significante para dois significados.

A paródia, por sua vez, entendida etimologicamente como “canto paralelo", já assinala o caráter duplo da escritura e, consequentemente, da leitura paródicas. Na opinião de Schnaiderman, "Vista como um dos elementos da oposição mundo/antimundo, a paródia torna-se algo inerente a toda uma tradição cultural” (1980, p.91). Para Maria Lucia P. de Aragão,

A paródia é uma forma de jogo em que se usa uma determinada técnica, cujos efeitos não são uniformes. Agride ou recusa os significados, enquanto reforça os significantes: ao potencializar um, enfraquece o outro. [...] A paródia se apresenta como um gênero ambíguo, denunciando o fracasso do poder constituído, numa sociedade cheia de contrastes [...] (1980, p.19-21, grifo nosso)

Logo, faz-se bem visível a proximidade entre as categorias riso, paródia e ironia, uma vez que são marcadas, entre outros fatores, pela contradição, pela ambiguidade e pela tensão. Outro traço fundamental, comum a esses discursos, é justamente a necessidade de participação do leitor na criação do sentido; afinal, cabe a ele, por 
meio de sua razão, localizar as ambiguidades inerentes a essas categorias. A consequência imediata da presença desses traços incongruentes e dissonantes é que essas modalidades - a saber, o riso, a paródia e a ironia - propõem a releitura do mundo, marcada por uma visão muito mais crítica. Entretanto, vale a pena reiterar: tal releitura depende do sujeito.

Esse olhar mais reflexivo e apurado para o mundo é alcançado devido ao fato de as categorias como o riso, a paródia e a ironia permitirem que apreendamos a realidade não a partir de esquemas mentais inconciliáveis e bipolarizados, mas, sim, através do choque, da tensão entre esses esquemas.

Portanto, partimos do princípio de que as modalidades motivadoras da presente pesquisa permitem que sejam avaliados os maniqueísmos, uma vez que a "verdade" proposta por essas categorias não está em "A" ou em "B", que se opõem, mas, sim, no choque, na tensão entre "A" e "B". É provável que nasça, como resultado desse embate, uma outra possibilidade de "verdade" que se distancie do maniqueísmo inicial.

Sabemos, porém, que nem sempre a literatura - aqui representada pelas categorias da ironia, paródia e riso - nos conduz a um contexto que transcende completamente nossa realidade concreta, repleta de maniqueísmos. Portanto, em contato com essas modalidades, assim como com a própria literatura, o sujeito tem a possibilidade de refletir e avaliar o mundo a seu redor.

O resultado dessa experiência pode ser a manutenção dos maniqueísmos anteriores, a criação de outros maniqueísmos ou, ainda, o acesso a ideias mais originais. Todo esse processo está subordinado ao sujeito receptor de textos caracterizados pela dissonância e, ainda, ao "produtor" desses discursos, que pode nutrir intenções as mais variadas, inclusive a de manipular.

Como se sabe, os principais participantes do jogo da ironia são o interpretador e o ironista. Acreditamos, entretanto, que a participação do interpretador ou do receptor ou ainda do leitor, no caso da ironia literária, é decisiva, na medida em que está nas mãos desse receptor decodificar - ou não - a significação irônica. 
Em razão disso, decidimos comentar a problemática do leitor logo no início deste livro, a fim de que se torne evidente, antes de mais nada, a fundamental importância desse elemento, que deve ser levado em consideração em quaisquer análises que se debrucem sobre textos cuja natureza é dissonante e contraditória.

Linda Hutcheon, estudiosa que segue essa mesma linha de raciocínio e a quem nos remetemos sempre neste livro, afirma que é realmente o destinatário quem decide se uma elocução é irônica ou não e, ainda, qual o sentido particular que ela, sendo irônica, pode assumir:

Esse processo ocorre à revelia das intenções do ironista (e me faz me perguntar quem deveria ser designado como o "ironista"). Não há garantias de que o interpretador vá "pegar" a ironia da mesma maneira como foi intencionada. Na verdade, "pegar" pode ser um incorreto e até mesmo impróprio; "fazer" seria muito mais preciso. (2000, p.28)

A pessoa designada por "ironista" geralmente é aquela que objetiva estabelecer uma relação irônica entre o dito e o não dito, todavia, nem sempre obtém sucesso em transmitir uma intenção específica. Logo, estamos autorizados a inferir que a ironia pode significar coisas diferentes, de acordo com os jogadores. Tal afirmação nos remete, com certeza, às palavras já citadas dos teóricos D. S. Likhatchóv e A. M. Pantchenko sobre o riso: "Esta relação do riso com a realidade é variável nas diferentes épocas e em diferentes povos" (apud Schnaiderman, 1980, p.90-1). Fica, portanto, assinalada, uma importante semelhança entre esses discursos: sua decodificação está submetida ao receptor e, ainda, ao contexto em que ele está inserido.

Seguindo esse raciocínio, textos caracterizados pela ambiguidade, pelo paradoxo, pela contradição e pela incongruência convocam o leitor a participar de maneira efetiva da construção de seu sentido, acionando seu "repertório" ou seu "conhecimento de mundo".

Desse modo, o receptor de textos irônicos, paródicos ou cômicos é valorizado, na medida em que é julgado capaz de perceber a 
ambiguidade subjacente a esses discursos. Nos três casos, a condição para que o sentido seja integralmente construído é a participação do leitor, que deve perceber, portanto, que está à frente de um enunciado dicotômico.

Assim, se é verdade que, do ponto de vista do ironista, "a ironia é a transmissão intencional tanto da informação quanto da atitude avaliadora além do que é apresentado explicitamente" (Hutcheon, 2000, p.28), também é fato que o trabalho do interpretador não pode ser simplesmente o de compreender corretamente. Para Hutcheon, nenhuma elocução é irônica em si, pois devemos sempre supor alguns interpretadores levando-a ao pé da letra:

atribuir ironia onde ela é intencional - e onde ela não é - ou recusar-se a atribuir ironia onde ela poderia ser intencional é também o ato de um agente consciente. [...] $\mathrm{O}$ interpretador como agente desempenha um ato - atribui tanto sentidos quanto motivos - e o faz numa situação e num contexto particulares. Atribuir ironia envolve, assim, inferências tanto semânticas quanto avaliadoras. (2000, p.29)

Portanto, o leitor se configura como elemento central dessa categoria de texto literário, já que deve localizar os aspectos que se encontram, implicitamente, em tensão. Assim, esse tipo de discurso - ambíguo, paradoxal, contraditório e incongruente - espera do leitor não apenas o sentimento de prazer suscitado pela leitura, mas também a responsabilidade do uso da imaginação e da perspicácia na construção do sentido. Esses discursos ocasionam, também, um tipo de prazer - o prazer estético, como veremos no capítulo 6 -, contudo, essa espécie de "deleite" só ocorrerá após a decodificação pelo leitor das "pistas" que sinalizam a incongruência.

O receptor do texto paródico, por exemplo, deve, pois, reconhecer que está diante de uma narrativa em cuja estrutura ocorre a sobreposição de dois planos: um superficial e outro implícito. Logo, se o leitor não conseguir identificar essa duplicidade que sustenta o texto paródico, ele eliminará boa parte de sua significação. Desse modo, não é possível pensar em paródia sem que se leve em conta 
esse colaborador imprescindível, que é o leitor. Afirma Maria Elena Pinheiro Maia:

A Estética da Recepção tem demonstrado que a colaboração do leitor para a decodificação da mensagem textual é imprescindível, pois alguns romances nos oferecem infinitas possibilidades de relacionamento, e cabe ao receptor, através de suas projeções representativas e da estrutura de apelo do texto, ocupar seus vazios, o não dito. Sendo assim, podemos considerar o texto artístico não só uma construção do autor, como também uma reconstrução do leitor. Cabe-lhe dirigir, organizar, interpretar o texto que oferece o autor. (1999, p.15)

A mesma estudiosa cita, ainda, um fragmento muito elucidativo da escritora Linda Hutcheon sobre a importância da participação do leitor na construção do sentido do texto literário:

A criação de mundos fictícios e o funcionamento construtivo, criador da linguagem no curso da poiesis são doravante partilhados conscientemente pelo autor e pelo leitor. Não basta mais pedir ao leitor que admita que os objetos de ficção são "como a vida"; espera-se que ele participe da criação de mundos, de sentidos, por meio da linguagem. Ele não pode se esquivar a esse apelo à ação, pois é pego na situação paradoxal de alguém que é forçado pelo texto a reconhecer o caráter fictício do mundo em cuja criação ele também toma parte e que sua própria participação penetra de maneira intelectual, criadora e talvez mesmo afetiva em uma prática humana que é bem real, uma espécie de metáfora dos esforços que ele faz todos os dias para "dar sentido" à experiência vivida. (1977, p.101-2, apud Maia, 1999, p.16-7)

Por conseguinte, o leitor deve, como um detetive, estar atento à categoria de textos examinada neste trabalho, reconstruindo seus sentidos e preenchendo seus espaços vazios ou os "não ditos", dando-lhe, enfim, a forma final por meio de suas projeções interpretativas.

Para finalizar este capítulo, remetamo-nos mais uma vez às precisas palavras de Linda Hutcheon sobre a ironia, categoria que, te- 
remos a oportunidade de estudar adiante, parece estar "na base" da construção da paródia e do riso:

A ironia não é necessariamente um caso de intenção do ironista (e logo de implicação), embora ela possa ser; ela é sempre, no entanto, um caso de interpretação e atribuição. (2000, p.74) 


\section{2}

\section{IRONIA}

Diz-se que a ironia irrita porque ela nega nossas certezas ao desmascarar o mundo como uma ambiguidade.

Linda Hutcheon

Discutiremos agora a problemática da ironia. Como se sabe, existem dois grandes tipos de ironia: aquela que se faz presente na vida cotidiana, simples, e a que mais nos interessa, a saber, a ironia literária. Muecke (1995, p.15) explica que a ironia desempenha seu papel na vida cotidiana e, nesse caso, essa "ironia popular" não oferece a seu receptor desafios complicados de interpretação.

Elucida tal tipo de ironia a frase "Sorria, você está sendo filmado", encontrada há alguns anos em inúmeros centros comerciais espalhados por todo o Brasil. Na verdade, deparando com esse enunciado, somos convidados não a esboçar um sorriso, como se sugere literalmente, mas, sim, somos avisados de que estamos submetidos a uma câmera e, sendo assim, caso ajamos ilicitamente, seremos identificados. Esse é, pois, um caso em que a ironia se faz presente no cotidiano, sem oferecer dificuldades maiores de interpretação. 
O que nos interessa mais, obviamente, é a ironia literária. Inserido nesse contexto, Muecke propõe uma série de questionamentos interessantes, que correspondem, também, a alguns dos objetivos mais importantes deste estudo: "o que é a ironia e como ela atua; para que serve e o que vale; de que é feita e como é elaborada; como a conhecemos quando a vemos; de onde provém o conceito e para onde vai" (1995, p.18).

Para começar, aquele estudioso confere à ironia certa função de equilíbrio ou correção. Segundo ele, a categoria em estudo pode restaurar o equilíbrio da vida quando ela está sendo levada muito a sério, ou, ao contrário, quando a vida não é levada de forma suficientemente séria, "estabilizando o instável, mas também desestabilizando o excessivamente estável.” (1995, p.19) As funções da ironia serão examinadas na seção "As principais funções da ironia" deste capítulo.

Outra indagação importante proposta por Muecke é a seguinte: "quais são as ocasiões das quais seria de esperar que excluíssemos a ironia [...]” (1995, p.20)? De acordo com ele, não faz sentido afirmar que as artes não verbais, como a música, a dança ou a arquitetura, tendem a ser menos irônicas do que a literatura, que tem a linguagem como princípio. $\mathrm{Na}$ verdade, qualquer pessoa bem informada sabe que pode haver muita crítica ou ironia em, por exemplo, uma pintura ou escultura artísticas.

O que se pode dizer, entretanto, é que a arte, qualquer que seja, tende a ser menos irônica quando a intenção de seu criador é mais simples, mais absorvente e mais imediata. Segundo Muecke,

é quando a literatura é mais musical, na poesia lírica, que, de modo geral, ela é menos irônica. E é quando uma pintura é "intelectual" ou "literária", seja ao fazer uma afirmação, seja ao transmitir uma mensagem, que pode ser irônica. (1995, p.20)

Conforme explica Muecke, o conceito de ironia é ainda vago, instável e multiforme. Para Nietzsche (apud Muecke, 1995, p.22), "somente se pode definir aquilo que não tem história" e é justa- 
mente nisso que reside a dificuldade de se conceituar a ironia, pois muito já se falou sobre ela. Assim,

A palavra ironia não quer dizer agora apenas o que significava nos séculos anteriores, não quer dizer num país tudo o que pode significar em outro, tampouco na rua o que pode significar na sala de estudos, nem para um estudioso o que pode querer dizer para outro. Os diferentes fenômenos a que se aplica a palavra podem parecer ter uma relação muito fraca. (...) Assim, o conceito de ironia a qualquer tempo é comparável a um barco ancorado que o vento e a corrente, forças variáveis e constantes, arrastam lentamente para longe de seu ancoradouro. (1995, p.22)

Dessa forma, Muecke comenta que cada estudioso segue as orientações que lhe são mais convenientes acerca da ironia, conforme o local e o momento histórico em que está inserido e de acordo com seu conhecimento de mundo. No caso específico deste trabalho, como foi explicado na introdução, pretende-se realizar um apanhado das teorias que se debruçam sobre essa categoria tão convidativa à análise e, posteriormente, aplicar as definições que mais se ajustam às obras escolhidas.

Muecke divide a ironia em duas grandes categorias: a ironia situacional ou observável e a ironia verbal ou instrumental. A fim de elucidar o primeiro caso, ele cita um fragmento da Odisseia, em que Ulisses retorna a Ítaca e, sentando-se disfarçado de mendigo em seu próprio palácio, escuta um dos pretendentes dizendo que ele (Ulisses) jamais poderia regressar a seu lar. Temos, nesse primeiro caso, uma ironia observável, que corresponde justamente a coisas vistas ou apresentadas como irônicas. Trata-se da "ironia do ladrão roubado", por exemplo. Muecke cita Schlegel:

Para Schlegel, a situação básica metafisicamente irônica do homem é que ele é um ser finito que luta para compreender uma realidade infinita, portanto, incompreensível. A isto podemos chamar de ironia observável da natureza, que tem o homem como vítima. (1995, p.39) 
A ironia verbal ou instrumental, por sua vez, ocorre quando há uma inversão semântica e, nesse caso, a ironia constitui em dizer uma coisa para significar outra, "como uma forma de elogiar a fim de censurar e censurar a fim de elogiar [...]” (Muecke, 1995, p.33). Nesse tipo de manifestação da ironia, temos um sujeito sendo irônico; logo, trata-se, em certa medida, de um modo de comportamento.

É possível imaginar, por exemplo, a seguinte situação: ao chegar à sala de aula, após o intervalo, a professora perde muito tempo de sua aula até que os alunos, agitados, tomem os seus devidos lugares e fiquem quietos. Então, ela espera pacientemente e de braços cruzados até que o silêncio seja instaurado. Quando pode finalmente falar e ser escutada, ela diz, calmamente: "É por esses e outros motivos que eu simplesmente adoro lecionar nesta sala de aula! A educação de vocês me comove!".

Temos aí, sem dúvida, uma ocorrência de ironia verbal. Como se percebe, não é possível tomar o sentido "ao pé da letra", o que significa que, se analisarmos literalmente a fala da professora, chegaremos a um significado diametralmente oposto ao sentido pretendido, que é, de fato, a insatisfação da professora com o comportamento dos alunos.

É preciso, então, que se compreenda justamente o oposto daquilo que é dito. Essa "exigência" é realizada pelo contexto. Dessa maneira, quando leva em conta a situação em que esse enunciado foi produzido, o receptor não pode admitir uma interpretação literal.

Portanto, diante da ironia observável, tem-se uma situação ou uma cena que devem ser percebidas pelo observador e julgadas irônicas, não existindo, assim, "alguém sendo irônico". Já na ironia verbal, há uma atitude irônica expressa por um sujeito, que faz uso de uma inversão semântica para transmitir sua mensagem, como foi elucidado no último exemplo.

É interessante notar, entretanto, que, mesmo se tratando de uma ironia verbal, é preciso que o contexto/situação sejam observados, caso contrário, o sentido pretendido pelo emissor não é alcançado pelo receptor. Seguindo esse raciocínio, no que diz respeito 
ao exemplo citado, se a diretora daquele colégio passasse em frente à sala de aula apenas no instante em que a professora dizia aquelas palavras irônicas, provavelmente entenderia o enunciado de forma literal. Isso ocorreria porque a diretora, sem presenciar os acontecimentos desde a chegada da professora, desconheceria a situação, o contexto em que a frase foi emitida.

Infere-se a partir desses comentários que, tanto no que diz respeito à ironia observável quanto à ironia verbal, a participação do receptor é imprescindível para que a significação irônica aconteça.

Embora tenha sido sugerido, é importante salientar que a ironia instrumental ou verbal é, portanto, aquela em que a linguagem é o instrumento. Muecke chama a atenção, ainda, para a necessidade de apresentação da ironia observável, caso contrário, é como se ela não existisse:

o que chamei de ironias observáveis existe apenas potencialmente nos fenômenos observados e torna-se efetivo somente através da apresentação; quanto mais hábil for a apresentação, mais clara é a situação irônica observada. (1995, p.85)

É fundamental comentar que também se considera como ironia verbal a apresentação verbal da ironia observável. Isso se explica pela constatação de que, se a intenção é "transcrever" uma situação irônica, a apresentação implicará habilidades verbais semelhantes. Em outras palavras, o fato irônico observado será escrito de maneira que as contradições sejam ressaltadas, o que justifica designar por ironia verbal a apresentação verbal da ironia situacional. Para Muecke,

Nem sempre é possível distinguir entre a ironia instrumental e a apresentação da ironia observável, mas geralmente a distinção é clara: na ironia instrumental, o ironista diz alguma coisa para vê-la rejeitada como falsa, unilateral, etc.; quando exibe uma ironia observável, o ironista apresenta algo irônico - uma situação, uma sequência de eventos, uma personagem, uma crença, etc. - que existe ou pensa que existe independentemente da apresentação. (1995, p.77) 
Agora que já foram comentadas as dificuldades de conceituação da ironia, os textos em que há maior probabilidade de encontrá-la e os dois grandes tipos de ironia - verbal e observável - podemos passar para a análise dos traços básicos dessa instigante categoria.

A sugestão de Muecke - estudioso que está norteando o presente trabalho sobre a ironia neste momento - se faz muito pertinente: investigar quais são as características comuns às manifestações irônicas de forma geral. Em outras palavras, ele propõe a busca das características que estão invariavelmente presentes em quaisquer expressões da ironia e que, portanto, se configuram como traços definidores, em particular, dos acontecimentos irônicos.

O contraste entre a aparência e a realidade é o traço básico de toda ironia. Conforme se observou nos exemplos irônicos citados anteriormente, algo é aparentemente afirmado, mas, na verdade, se percebe uma mensagem completamente diferente. A tensão entre aparência e realidade pode expressar-se por meio de uma oposição, contradição, contrariedade, incongruência ou, ainda, através de uma incompatibilidade.

Sendo assim, essa característica básica de toda ironia - o contraste entre aparência e realidade - marca não apenas a ironia verbal, mas também a ironia observável, pois, neste último caso, se constata também uma incongruência. Se pensarmos, por exemplo, num cientista que morre vítima de uma fórmula química de que ele próprio é autor, percebemos um efeito de sentido irônico criado graças à seguinte incompatibilidade: entre o que se pensa sobre um cientista (que ele conheça as propriedades de sua "criação") e aquilo que corresponde à verdade (o fato de que, possivelmente, ele não conheça, na realidade, a fórmula criada). Excetuando-se, obviamente, a provável ocorrência de um acidente, está-se, pois, diante de uma ironia observável, motivada pela contradição que existe entre aparência e realidade.

É importante observar, entretanto, que nem tudo o que é diferente do que parece ser é exemplo de ironia. A mentira e o embuste expressam também, por exemplo, um contraste entre aquilo que se aparenta e o que realmente é. Portanto, a oposição entre os concei- 
tos de aparência e de realidade não caracteriza exclusivamente a ironia. Conforme explica Muecke:

Certos logros, como mentiras, embustes, hipocrisia, mentiras convencionais e equívocos, que pretendem transmitir uma verdade mas não o fazem, também podem ser considerados contrastes de aparência e realidade. Mas, como não são considerados ironia, é evidente que a ironia tem outro elemento ou elementos além desse contraste. (1995, p.54)

É verdade que a ironia e o embuste são "vizinhos próximos", inclusive porque a palavra ironia provém do termo latino dissimulatio. No entanto, é necessário ficar claro que o ironista dissimula ou finge não para ser acreditado, mas para ser compreendido. Para Muecke, mais uma vez:

Nos logros existe uma aparência que é mostrada e uma realidade que é sonegada, mas na ironia o significado real deve ser inferido ou do que diz o ironista ou do contexto em que o diz; é "sonegado" apenas no fraco sentido de que ele não está explícito ou não pretende ser imediatamente apreensível. Se entre o público de um ironista existem aqueles que não se dispõem a entender, então o que temos em relação a eles é um embuste ou um equívoco, não uma ironia [...] (1995, p.54)

Fica fácil perceber, dessa maneira, que o estudo da ironia exige o reconhecimento de um sentido literal e de outro figurado, uma vez que esse "recurso" se constitui de um significante para dois significados contraditórios ou incompatíveis. Aquele que pratica a ironia qualifica o enunciatário, pois o julga capaz de perceber os índices que sinalizam esse procedimento, participando, assim, da construção da significação irônica.

Desse modo, como explicou Muecke na citação acima, o ironista pretende que o sentido seja apreendido pelo receptor da ironia, porém não imediatamente; almeja, ao contrário, que aquele a quem a ironia foi dirigida interprete as pistas que sugerem um discurso irônico, colaborando, por conseguinte, para a construção do sentido. 
O mesmo não se verifica no discurso mentiroso, no qual, ainda que exista, como na ironia, a presença de um significante recobrindo dois significados que se contrapõem, o enunciador tenta apagar de sua fala os índices dessa inversão ou ambiguidade, pretendendo que o enunciatário aceite como verdade o que não é, desqualificando-o, consequentemente.

A presença de um ironista e de uma pretensão irônica constituem-se como características básicas apenas da ironia verbal ou instrumental, como designa Muecke (1995, p.55). A ironia observável - por exemplo, a ironia do ladrão roubado - não é marcada pela presença de ironista e, portanto, também não há pretensão irônica.

A estrutura dramática é outro traço interessante da ironia, sobretudo da ironia verbal ou instrumental, que é, de acordo com Muecke (1995, p.58), "um jogo para dois jogadores". Como foi dito, nesse tipo de ironia, aquele que a pratica propõe um texto, entretanto, de alguma forma, motiva o leitor a rejeitar o seu sentido literal em favor de um significado implícito e contrastante. É justamente nisto que consiste essa estrutura dramática caracterizadora da ironia: duas pessoas envolvidas na construção de uma mensagem.

É importante comentar, ainda, que os tais sinais que apontam para um sentido sub-reptício podem ser parte do texto - contradições e exageros - ou acompanhar o texto, no caso de serem, por exemplo, gestos. Para Muecke, "alternativa ou adicionalmente, o ironista pode ser capaz de confiar em seu público que tem os mesmos valores, costumes ou conhecimento que ele mesmo" (1995, p.59)

A ironia observável, por sua vez, não está desprovida de uma estrutura dramática parecida. A diferença é que, nesse tipo de ironia, os papéis do ironista e do público intérprete são fundidos num só: o observador com um senso de ironia. Segundo Muecke,

O observador irônico reconhece ou descobre que algo pode ser olhado como na verdade o inverso, em algum sentido, daquilo que pareceu ser à primeira vista ou a olhos menos aguçados ou a mentes menos informadas [...] A maioria das ironias observáveis chegam até nós já prontas, já observadas por alguém mais e apresentadas totalmente 
formadas no drama, na ficção, no filme, nas pinturas e desenhos, nos provérbios e ditos [...] Ver alguma coisa irônica na vida é apresentá-la a alguém como irônica. Esta é uma atividade que exige, além de uma larga experiência de vida e um grau de sabedoria mundana, uma habilidade, aliada a engenho, que implica em ver semelhanças em coisas diferentes, distinguir entre coisas que parecem as mesmas, eliminar irrelevâncias, ver a madeira a despeito das árvores e estar atento a conotações e ecos verbais. (1995, p.61)

Assim, não se devem comparar os receptores das ironias verbal e observável e concluir que aquele a quem se dirige a ironia verbal é mais ativo, uma vez que, como se explicou na citação acima, o papel do observador irônico é mais ativo e mais criativo do que sugere a palavra "observador".

Faz-se também muito interessante investigar se existe ou não uma sensação particular que esteja relacionada à ironia e deva fazer parte de sua definição. Como será observado mais adiante, na seção intitulada "A carga afetiva da ironia", experimentam-se sensações diferentes, de acordo com o tipo de ironia, que pode ser trágica, cômica, satírica, paradoxal, entre outras.

Para Muecke, porém, existem pelo menos duas sensações comuns a todas as ocorrências de ironia. A primeira seria a "curiosa sensação especial de paradoxo, do ambivalente e do ambíguo, do impossível tornado efetivo, de uma dupla realidade contraditória" (1995, p.65). A segunda seria uma sensação de libertação que, para Muecke, é característica da ironia, mas não peculiar a ela.

A sensação de liberdade provocada pela ironia relaciona-se, segundo esse estudioso, aos "sentimentos de superioridade e divertimento e, simbolicamente, a um olhar do alto de uma posição de poder ou conhecimento superior" (1995, p.67). Thomas Mann afirma:

a ironia é um olhar claro como o cristal e sereno, todo abrangente, que é o próprio olhar da arte, isso quer dizer: um olhar da maior liberdade e calma possíveis e de uma objetividade não perturbada por qualquer moralismo. (Apud Muecke, 1995, p.67-8, grifos nossos) 
Muecke acentua, ainda:

A autoconsciência do observador irônico enquanto observador tende a acentuar sua sensação de liberdade e induz um estado de satisfação, serenidade, alegria ou mesmo de exultação. Sua consciência da inconsciência da vítima leva-o a ver a vítima como se estivesse amarrada ou presa numa armadilha onde ele se sente livre; comprometida onde ele se sente descompromissado, agitada por emoções, fustigada, ou miserável onde ele está indiferente, sereno, ou mesmo movido ao riso; confiante, crédula ou ingênua, onde ele é crítico, cético, ou disposto a parar o julgamento. Onde sua própria atitude é a de um homem cujo mundo parece real e significativo, ele considerará o mundo da vítima ilusório ou absurdo. (1995, p.68)

Nesse comentário de Muecke fica bem claro que as sensações de superioridade e de liberdade são características da ironia. Ambos os participantes da construção do sentido irônico podem gozá-las. Assim, ironista e receptor da ironia podem sentir liberdade em contato com uma manifestação irônica - o primeiro porque propõe um "sentido oculto" que apenas ele conhece em princípio, e o segundo porque tem condições de, por meio das pistas dadas pelo ironista, chegar ao sentido irônico. No caso da ironia observável, essa sensação também se faz presente: o observador irônico se sente superior e livre quando considera uma situação - tida pela maioria como "normal" - incongruente.

\section{Ironia romântica}

Distanciando-se da abordagem mais comum de ironia - um significante para dois significados -, a ironia romântica é fruto da intervenção do narrador em seu relato. Assim, a narrativa prossegue normalmente até que, em determinado momento, e, obviamente, almejando fins específicos, o narrador "intromete-se", revela-se, tecendo comentários, críticas ou mesmo refletindo sobre a criação literária. 
Odil de Oliveira Filho nomeia esse narrador de contador de histórias, uma vez que, inserindo-se no relato e deixando momentaneamente a objetividade de lado, se aproximaria justamente das narrativas orais, marcadas pela presença de uma categoria mais popular, que é a do contador.

É importante salientar que esse tipo de narrador aparece em momentos específicos da história literária. Assim, no final do século XVIII e ainda no século XIX, o "contador de histórias" fez-se muito presente, marcando concretamente sua presença e intervindo no plano do enunciado. Essas "aparições" frequentes nesse momento legitimam, sem dúvida, os ideais românticos de originalidade e de subjetividade que assinalaram esses séculos. De acordo com Karin Volobuef,

O Romantismo, mediante o recurso à ironia romântica, deixa entrever o fazer poético e institui a primazia do indivíduo (criador) sobre a obra (objeto criado). Aquilo que se costuma denominar ironia romântica constitui-se como uma determinada escritura poética que sinaliza, dentro do texto, a presença de seu autor. Em suma, trata-se da ascendência do autor em relação à obra. (1999, p.90-1, grifos nossos)

Posteriormente, com o início do movimento literário seguinte o realismo -, o narrador se abstrai dos fatos que narra, já que a "regra" é a busca da objetividade. Num terceiro momento, expresso durante o século XX, as relações entre narrador e leitor são subjetivadas, superando-se assim a distância entre um e outro. Conforme explica Odil de Oliveira Filho,

descarta-se toda a espécie de "truque" para criar a aparência de realidade buscada pelo romance tradicional, desfaz-se a ordem cronológica e investe-se no relativo e no subjetivo das ações humanas; o narrador onisciente é eliminado, assim como o narrador imparcial, suprimindo-se o mais possível a distância entre o narrador e o mundo narrado. (1993, p.73) 
É necessário não considerar os períodos comentados de maneira rígida, uma vez que sempre houve escritores que não se encaixaram nas tendências literárias seguidas em determinados momentos. No Brasil, para citar apenas um exemplo, temos Machado de Assis, que, inserido no século XIX, não se submeteu aos ditames do realismo no que diz respeito à objetividade narrativa, criando narradores interventivos ou, como designou Odil de Oliveira Filho, autênticos "contadores de história". No entender de Beth Brait,

A ironia romântica pode ser traduzida como "o meio que a arte tem para se autorrepresentar", como articulação entre filosofia e arte, poesia e filosofia, na medida em que não estabelece fronteiras entre princípio filosófico e estilo literário. Além desse aspecto caracterizador [...] há ainda outros a serem sublinhados: a ideia de contradição, de duplicidade como traço essencial a um modo de discurso dialeticamente articulado; o distanciamento entre o que é dito e o que o enunciador pretende que seja entendido; a expectativa da existência de um leitor capaz de captar a ambiguidade propositalmente contraditória desse discurso. (1996, p.29, grifos nossos)

Possivelmente, o mais curioso na expressão da ironia romântica seja o efeito de sentido produzido nos discursos por ela caracterizados. Para Linda Hutcheon (1985, p.45), "a ironia romântica, evidentemente, serviu menos para subverter a ilusão do que para criar uma nova ilusão."

Assim, esse tipo de ironia cria efeitos de sentido contraditórios: ao permitir que o leitor "veja" os mecanismos do "fazer poético", desnudando o caráter ficcional da narrativa, o narrador, por um lado, legitima a ficcionalidade e destrói a verossimilhança do relato; entretanto, analisando de maneira inversa, o narrador, por meio da ironia romântica, confere certa aparência de "realidade" à narrativa que tece e institui, de certo modo, uma forte "ilusão de veracidade", ultrapassando, ao que parece, a sensação de verossimilhança.

Por se constituírem como excertos bastante representativos do tipo de ironia examinado nesse momento, escolhemos alguns frag- 
mentos do romance $O$ arco de Sant'Ana, do escritor português Almeida Garrett, localizado literariamente no romantismo. As passagens a seguir exemplificam bem não apenas os sentidos gerados num texto literário a partir da utilização da ironia romântica, mas também sinalizam algumas das pretensões do narrador ao utilizá-la - afinal, é sempre com intenções específicas que um narrador se vale desse tipo especial de ironia. Vamos ao primeiro fragmento:

Cá estamos junto à veneranda estátua do velho Porto que, rodeado de assopradas tripas, olha, como de próprio trono, para sobre os domínios de sua jurisdição. Não tinha ainda, naquele tempo, iconoclástica brocha ousado assarapantar de vulgar e rabugenta oca, nem arrebicar de crasso vermelhão aquele primor do cinzel portuense, que então resplandecia em toda a nitidez do primitivo granito. Cometamos, pois, o desculpável anacronismo, se o é, de saudar o respeitável emblema de nossa ilustre cidade, e vamos direitinhos, sem mais cumprimento nem mesura, aos passos da Sé, ou passos do bispo, como hoje se diz e talvez então se dissesse já. Creio que dizia. O precioso manuscrito donde tiro esta verdadeira história lê "paços do bispo": na sua fé vá como ele quer. (s. d., p.45-6)

Mesmo descontextualizado, é possível notar que o trecho acima, situado no início do relato, não faz parte da história enquanto série de acontecimentos narrados, mas, sim, de um "mundo discursivo" ou "mundo comentado". Trata-se, portanto, de uma manifestação especial do narrador que, nesse momento, reforça sua existência com o leitor, por meio da utilização dos verbos na primeira pessoa do plural. O apelo à ironia romântica nesse trecho garante, como se pode perceber, a verossimilhança narrativa.

Ainda em relação à mesma narrativa, o romance não faz apenas alusão a objetos extratextuais, mas também a assuntos literários que, em razão de serem verídicos (por se encontrarem fora do espaço ficcional), instauram, mais do que a verossimilhança, certa "ilusão de veracidade", aqui compreendida como uma forte apro- 
ximação entre a obra literária e o mundo exterior. Essa característica pode ser muito bem observada em:

Deixá-lo, deixá-lo e transportemo-nos nós, amigo leitor, para mui diverso, posto que não mui apartado lugar. Façamos, com a rapidez com que em um teatro britânico se faz, a nossa mutação de cena; e deixai gemer as unidades de Aristóteles, que ninguém desta vez lhe acode. (s. d., p.45)

Essa asserção é, com certeza, bastante significativa, uma vez que remete o leitor à oposição ferrenha dos românticos em relação às regras classicistas. Como foi mencionado, Almeida Garrett é um romântico e, como tal, não se submete à lei das três unidades de Aristóteles; desse modo, o narrador se vale da ironia romântica para desautorizar esse filósofo, ao "pular" bruscamente de cena, levando consigo o leitor.

Ainda sobre esses fragmentos que enviam o leitor para fora do texto a fim de assegurar o "efeito de realidade", é preciso dizer que, mesmo quando não representam fatos, como é o caso do trecho comentado acima, essas passagens são, muitas vezes, verificáveis, garantindo, portanto, semelhante efeito de sentido. Isso se dá também em:

Vasco, o nosso estudante, pois não há mister de mais mistérios - e perdoem-me o "mister" que aqui veio mais pela graça da aliteração do que por outra coisa: tão safado e sáfaro o trazem por aí os periódicos e os dramatistas, que ninguém já pode com ele! (s. d., p.100).

No fragmento acima, se faz bem nítida a ironia romântica, já que o narrador está praticamente revelando a maneira crítica por meio da qual constrói o seu texto. Trata-se, em outras palavras, de um trecho onde se representa o próprio processo de enunciação. Como já foi comentado, se ocorre, por um lado, em casos semelhantes a este, uma revelação do caráter ficcional da narrativa, por outro, cria-se mais do que um efeito que certifique a verossimilhança, ocorre uma viva ilusão de veracidade. 
Em outro momento da narrativa de Garrett, eis uma nova investida do narrador:

Há um vazio sempre, um oco de incerteza em todas as comoções populares, de que é fácil aproveitar-se qualquer com mediana habilidade, uma vez que esteja de sangue frio, e lhe lance a tempo um nome, uma palavra, uma frase, seja qual for. E não importa a ideia; o que se quer é o símbolo. Da coisa simbolizada não é tempo de tratar agora, não há sossego para a examinar: depois veremos. Toma-se a palavra, o nome, a bandeirola - um chapéu de três ventos que seja, como o outro dia sucedeu em França - e vai-se para adiante. Fica, é verdade, o direito salvo para chorar depois o erro, lamentar a precipitação do momento, e conspirar cada um contra a sua própria obra; mas é tudo o que fica. $\mathrm{E}$ não obstante isso, assim se fez sempre, assim se há de sempre fazer: porque o povo nunca se excita fortemente pelo bom do que há de vir, senão pelo mau e insuportável do que é. (Garrett, s. d., p.125-6, grifos nossos)

Esse trecho denota muita sabedoria. Há nele, sem dúvida, uma reflexão sobre o próprio tempo da escrita do romance, em que se insurgiam, uns contra os outros, liberais e conservadores. Garrett, soldado liberal, metaforiza, assim, na história da insurreição popular contra o bispo do Porto, o desejo de união do povo contra o autoritarismo do Estado e da Igreja de seu tempo.

É possível entrever, ainda, remissão clara à Revolução Francesa e, como já foi visto, essas referências a situações extratextuais sempre auxiliam na construção de um efeito de sentido maior do que a simples verossimilhança: a ilusão de veracidade. Além disso, a sensatez dessas palavras alerta justamente para a ingenuidade e insegurança do povo que, segundo o narrador, está sempre desorientado em relação a seus direitos e às mazelas das quais é ou será ainda vítima. Podemos supor, ainda, uma crítica sutil à burguesia e, nesse caso, esse fragmento nos remete à oposição entre românticos e burgueses, tão significativa para a literatura da segunda metade do século XVIII e XIX.

É válido reiterar que são passagens absolutamente desnecessá- 
rias ao encadeamento dos fatos narrados. Isso quer dizer que os trechos citados acima são caracterizados por estarem fora da diegese, integrando, assim, não a história em si, mas uma espécie de "mundo comentado".

Por conseguinte, há em $O$ arco de Sant'Ana, como em outros textos literários marcados pela presença da ironia romântica, elementos que extrapolam a questão da verossimilhança; isso se dá, como se pôde perceber, porque tais elementos não se encontram inseridos nos domínios da diegese - considerada como série de fatos narrados. Consequentemente, tais manifestações reforçam, na obra literária, uma forte sensação de ilusão de veracidade, aqui entendida, reitera-se, como uma intensa aproximação entre a obra literária e a realidade exterior.

Esperamos que tenha ficado claro, ainda, pela observação dos fragmentos da obra de Garrett, que, se o narrador faz uso da ironia romântica, é sempre em busca da realização de uma intenção específica, que deve ser "descoberta" pelo leitor. A opinião de Muecke vem ao encontro das ideias defendidas no presente trabalho:

$\mathrm{Na}$ ironia romântica, a inerente limitação da arte, a incapacidade de uma obra de arte, como algo criado, de captar plenamente e representar a complexa e dinâmica criatividade da vida é, por sua vez, imaginativamente levada à consciência quando se the atribui conhecimento temático. Deste modo, a obra transcende a mimese ingênua e adquire uma dimensão aberta que pode convidar-nos à posterior especulação. (1995, p.95, grifos nossos)

Portanto, os textos literários marcados pela ironia romântica, ao mesmo tempo em que chamam a atenção, explícita ou implicitamente, para sua condição específica de texto literário e, pois, para sua natureza ilusória, extrapolam a mimese ingênua, criando o que achamos por certo chamar "ilusão de veracidade". 


\section{Ironia no teatro}

A maneira como a ironia se manifesta no teatro é bastante interessante. Sua qualidade depende do fato de a plateia dispor de informações verdadeiras sobre uma determinada situação ou obter uma informação junto com a vítima. Segundo Muecke,

No palco, este artifício de consciência discrepante pode ser variado de diversas maneiras: somente a plateia pode entender a plena importância do que é dito; uma ou mais personagens podem saber no todo ou em parte o que a plateia sabe; uma personagem que está desinformada pode falar ou ouvir em ignorância o que é de seu interesse ou desinteresse. (1995, p.75)

Como se vê, Muecke considera irônico, no teatro, o fato muito corriqueiro de alguns dramaturgos brincarem com a questão da posse de algumas informações fundamentais apenas pela plateia. Assim, em $O$ noviço, texto teatral de Martins Pena, encontramos inúmeras passagens parecidas com a seguinte:

Ambrósio - Dous filhos te ficaram do teu primeiro matrimônio. Teu marido foi um digno homem e de muito juízo; deixou-te herdeira de avultado cabedal. Grande mérito é esse...

Florência - Pobre homem!

Ambrósio - Quando eu te vi pela primeira vez, não sabias que eras viúva rica. (À parte:) Se o sabia! (Alto:) Amei-te por simpatia.

Florência - Sei disso, vidinha.

Ambrósio - E não foi o interesse que me obrigou a casar-me contigo.

Florência - Foi o amor que nos uniu.

Ambrósio - Foi, foi, mas agora que me acho casado contigo, é de meu dever zelar essa fortuna que sempre desprezei.

Florência, à parte - Que marido!

Ambrósio, à parte - Que tola! (2003, p.11)

O enredo principal dessa peça consiste no seguinte: Ambrósio, espertalhão, pretende "dar o golpe do baú" em Florência, mulher 
ingênua e viúva rica. Quem salvará essa personagem da ruína é Carlos, seu sobrinho, que, por sugestão maldosa de Ambrósio, se encontra encerrado em uma espécie de seminário para padres.

É interessante notar que Martins Pena faz uso dos apartes a fim de mostrar quem as personagens realmente são. E o que cria o efeito irônico é o fato de que teoricamente apenas a plateia ouve esses apartes. Ou seja, algumas personagens mantêm-se completamente alheias a informações essenciais a sua vida.

No caso do fragmento acima, Florência ignora as verdadeiras intenções de Ambrósio e prejudica-se por isso, na medida em que é manipulada por ele. Esse recurso, além de criar um curioso efeito irônico, envolve a plateia, que, conhecendo verdades que as demais personagens desconhecem, torce por uma reviravolta, espera ansiosa que a verdade se explicite.

A plateia pode, portanto, saber de antemão o resultado ou o verdadeiro estado das coisas, como se observou no fragmento de $\mathrm{O}$ noviço. Mas também há casos em que o público recebe as informações ocultadas juntamente com a vítima. Conforme esclarece Muecke,

existem ironias efetivas nas quais a plateia é mantida sem informação. Shirley Hazzard, em Transit of Venus, lança uma clara cilada ao leitor, deixando-o saber que uma personagem que há pouco dissera à heroína: "Nós, pessoas comuns, podemos dizer mais ou menos como certas coisas provavelmente irão ocorrer conosco" vai morrer três meses mais tarde num desastre de avião, mas não o informa, até o fim do romance, de que a heroína estará no mesmo avião. (1995, p.75-6)

\section{A ironia instituindo hierarquias?}

O conceito de que a ironia é negativa, amplamente destrutiva, parece ser defendido, em épocas diferentes, por quase todos que receberam um ataque irônico (ou não conseguiram ver a ironia de maneira nenhuma) ou por aqueles para quem o sério ou o solene e o unívoco são o ideal. Obviamente, 
esse último grupo incluiria não apenas os desprovidos de senso de humor, mas também aqueles cujos compromissos politicos os levassem a desejar, talvez para propósitos didáticos, um discurso de engajamento sem ambiguidade.

Linda Hutcheon

A problemática da hierarquia que a ironia em geral ocasiona no momento de sua manifestação é extremamente importante. Segundo Booth, estudioso citado por Linda Hutcheon, quer se perceba, quer não, a ironia tem o poder de excluir e de humilhar ou, ao invés disso, de criar "comunidades amigáveis" (1974, p.28, apud Hutcheon, 2000, p.37). Do ponto de vista do ironista, é possível supor a seguinte hierarquia criada pela ironia: "aqueles que a usam, depois aqueles que a 'pegam' e, no fundo, aqueles que não a 'pegam'” (2000, p.37).

Hutcheon chama a atenção para o fato de que, sob a ótica do interpretador, as "relações de poder" entre os "jogadores" da ironia podem parecer bem diferentes:

Não é que a ironia cria comunidades ou grupos fechados; em vez disso, eu quero argumentar que a ironia acontece porque o que poderia ser chamado de "comunidades discursivas" já existe e fornece o contexto tanto para o emprego quanto para a atribuição da ironia. (2000, p.37)

Logo, no entender dessa estudiosa, as pessoas se encaixam nessas comunidades de discursos e cada uma dessas comunidades tem suas características e suas convenções próprias, conhecidas e compartilhadas entre os integrantes desse "grupo discursivo".

Assim, por exemplo, uma piada sobre um determinado escritor português, compartilhada entre professores de literatura, poderia não ser compreendida por um grupo formado por matemáticos. $\mathrm{O}$ fato de ser entendida ou não depende do repertório dessas pessoas. Para Hutcheon, portanto: 
Isso não é uma questão de elitismo de grupos fechados; é apenas uma questão de contextos experienciais e discursivos diferentes. De uma certa maneira, se você entende que a ironia pode existir (que dizer uma coisa e querer dizer outra não é necessariamente uma mentira) e se você entende como funciona, você já pertence a uma comunidade: aquela baseada no conhecimento da possibilidade e natureza da ironia. Não é que a ironia cria comunidades, então; é que comunidades discursivas tornam a ironia possível em primeiro lugar. (2000, p.37-8)

Seguindo esse raciocínio, portanto, quanto mais o contexto for compartilhado entre os "jogadores" da ironia, em menor quantidade e menos óbvias serão as pistas que sinalizarão o procedimento irônico.

Linda Hutcheon assinala ainda a questão da não apreensão da ironia por parte de seu receptor. Para ela, a não realização do discurso irônico, ou seja, o fato de, muitas vezes, o interpretador não conseguir acessar a ironia, ou de não poder "pegá-la" não deve ser associado, como comumente é, à "competência" do interpretador.

$\mathrm{Na}$ verdade, na opinião dessa estudiosa, esse termo - "competência” - tem uma conotação bastante desconfortável, na medida em que aponta para a exclusão daquele que não compreendeu a manifestação irônica.

O mais coerente é, pois, para Hutcheon, argumentar que o problema de a ironia "falhar" está relacionado, pelo menos em parte, não à capacidade - ou a falta de - do interpretador, mas, sim, ao fato de as pessoas envolvidas no "jogo irônico" pertencerem a diferentes comunidades discursivas. Segundo Hutcheon:

a superposição de comunidades discursivas não envolve necessariamente um consenso obrigatório, mas fornece pelo menos alguma similaridade de preocupação, interesse ou simplesmente conhecimento (de contextos, normas ou regras, intertextos) que capacitam os participantes a desempenharem jogadas de comunicação indireta. (2000, p.41)

Por conseguinte, no entender de Linda Hutcheon, a ironia não cria comunidade alguma, excluindo ou incluindo pessoas e crian- 
do, consequentemente, hierarquias. Ao contrário, as comunidades discursivas tornam a ironia possível, em primeiro lugar. Voltaremos a essa questão no capítulo 5 .

\section{A carga afetiva da ironia}

Diferentemente da metáfora ou da metonímia, a ironia tem arestas; diferentemente da incongruência ou justaposição, a ironia consegue deixar as pessoas irritadas; diferentemente do paradoxo, a ironia decididamente tem os nervos à flor da pele.

Linda Hutcheon

Conforme será visto no próximo capítulo, na grande maioria de suas manifestações, a ironia envolve a atribuição de uma atitude avaliadora e até mesmo julgadora e é justamente aí que a dimensão emotiva ou afetiva também se faz presente. Quando se pretende um estudo mais pormenorizado sobre a "carga afetiva da ironia", as teorias da intencionalidade se debruçam geralmente sobre o "realizador" da ironia:

Os termos nos quais as teorias de intencionalidade apresentam esse conceito são aqueles da posição julgadora negativa do ironista, como se infere através de um tom de deboche ou ridículo ou desprezo. E é esse tom que, diz-se, sugere aos interpretadores que essas posições de atitude são, na verdade, de emoção, que se poderia ler como traindo algum engajamento afetivo da parte do ironista. (Hutcheon, 2000, p.64)

Linda Hutcheon deixa bem claro, entretanto, que os ironistas não são os únicos a ser atraídos emocionalmente para dentro da ironia. Aqueles que já foram alvos da ironia conhecem muito bem os sentimentos de irritação, chateação e mesmo raiva proporcionados por uma investida irônica.

Ainda mesmo quando somos maus interpretadores e não conseguimos "captar" a ironia, sentimos um embaraço e um desconforto 
profundos, ligados à sensação de que fomos excluídos de um determinado grupo que participou da construção do sentido irônico. Como afirma Hutcheon:

Quando a ironia é usada às suas custas, você se torna seu alvo - quer você compreenda a ironia pretendida, quer não. Os interpretadores, entretanto, podem sentir raiva pelas atitudes ou pelos valores inferidos na elocução irônica, e para isso eles teriam apenas de entender, e não compartilhar ou apreciar aquelas atitudes. (2000, p.70)

A dimensão das emoções suscitadas pela ironia é realmente muito ampla: seus "efeitos emocionais", digamos assim, cobrem uma escala que vai do prazer à dor, do deleite à raiva. Acima, foram comentadas, em linhas gerais, as sensações de ódio ou raiva que podem, de acordo com a situação, acometer tanto o ironista quanto o interpretador da ironia.

Conforme foi dito, no caso do ironista, esse tipo de sentimento acontece quando há uma posição julgadora negativa do "realizador" da ironia em relação a seu "alvo". No caso do receptor da ironia, a raiva ou o ódio podem eclodir quando, ao compreender o discurso irônico, percebe-se "alvo", não apreciando, assim, o sentido sugerido por aquela elocução. Aquele que recebe a ironia pode, ainda, sentir-se desconfortável e até mesmo humilhado quando não consegue apreender o discurso irônico.

As ocorrências irônicas podem, no entanto, despertar emoções bem diferentes da ira ou da raiva. A ironia, em muitas de suas manifestações, é usada também com o intuito de divertir. É possível pensar na seguinte situação: um grupo de pessoas está em um apartamento estudando a língua alemã. Num dado momento, um intenso barulho, caracterizado por xingamentos e objetos atirados às paredes, irrompe e invade o silêncio necessário ao estudo.

Eles se desconcentram e percebem que a algazarra vem do apartamento ao lado. Como o barulho não para e devido ao fato de uma cadeira ter sido arremessada na porta do apartamento onde estava o grupo, causando grande estrondo, um dos estudantes afirma: 
“- Gente fina é outra coisa!”, e todos riem. Obviamente, acima da crítica à grosseria daqueles vizinhos, está o desejo de divertir, que se concretiza pelo uso oportuno da ironia.

Se a raiva e a hostilidade são, em muitos casos, consequências da utilização da ironia, e o humor, como se viu, também pode resultar de uma ocorrência irônica, há, por outro lado, um outro efeito interessante: um distanciamento relativamente sem emoção por parte do ironista. Segundo Linda Hutcheon, porém, essa falta de envolvimento pode ser fingida:

Ao se apresentarem como se estivessem controlados e distantes em seu escárnio, os ironistas conseguem parecer persistentemente calmos, quase, pode-se acreditar, descomprometidos. Como isso sugere, parece haver um elemento de presença envolvido aqui, de "distanciamento fingido" e "neutralidade aparente". [...] Nem todos os comentaristas veem tal posição como totalmente negativa: para o ironista, ela tem o potencial de moderar e regular o excesso; ela pode até aliviar a tensão. (2000, p.69)

Como se nota, em todos os casos comentados aqui, há, sim, uma dose variável de afetividade proveniente do uso da ironia. Como afirma Hutcheon:

Quer se perceba a ironia como sinalizando, por um lado, um menosprezo zombeteiro, quer, por outro, distanciamento ou "a aresta cortante de não se importar", me parece que a emoção está, de alguma maneira, envolvida aqui, potencialmente na atribuição e, é claro, na intenção. (2000, p.65)

É importante deixar claro que a estudiosa citada considera a "atribuição" da ironia o momento de sua interpretação e, portanto, esse termo está relacionado àquele que recebe e interpreta ou "atribui” a ironia. Infere-se disso, como se pretendeu demonstrar no decorrer desta explicação, que a emoção gerada por uma manifestação irônica envolve tanto o ironista quanto o receptor da ironia. 
Portanto, ao contrário de alguns estudos que afirmam que a ironia é um modo de distanciamento intelectual, parece que as ocorrências irônicas estão sempre permeadas por um traço emocional. Mais uma vez, finalizemos com Linda Hutcheon:

A ironia sempre tem uma aresta; ela às vezes tem um "ferrão". Em outras palavras, existe uma "carga" afetiva na ironia que não pode ser ignorada e que não pode ser separada de sua política de uso se ela for dar conta da gama de respostas emocionais (de raiva a deleite) e os vários graus de motivação e proximidade (de distanciamento desinteressado a engajamento apaixonado). Às vezes a ironia pode mesmo ser interpretada como uma retirada de afeto; às vezes, entretanto, há um engajamento deliberado de emoção. (2000, p.33)

\section{As principais funções da ironia}

Com a ironia você sai do reino do verdadeiro e do falso e entra no reino do ditoso e do desditoso - de maneiras que vão muito além do que sugere o uso desses termos na teoria dos atos da fala. A ironia remove a certeza de que as palavras signifiquem apenas o que elas dizem.

Linda Hutcheon

Tradicionalmente, há uma forte tendência em se considerar como única função da ironia o contraste semântico entre o que é afirmado e o que é significado. Para Linda Hutcheon (1985, p.73), entretanto, a ironia julga e essa é a sua função essencial, frequentemente tratada como se fosse demasiado óbvia para justificar a discussão.

Logo, essa estudiosa divide as funções da ironia em duas: uma semântica, contrastante, e outra pragmática, avaliadora. Hutcheon explica: 
A função pragmática da ironia é, pois, a de sinalizar uma avaliação, muito frequentemente de natureza pejorativa. O seu escárnio pode, embora não necessariamente, tomar a forma de expressões laudatórias, empregues para implicar um julgamento negativo; ao nível semântico, isto implica a multiplicação de elogios manifestos para esconder a censura escarnecedora latente. (1985, p.73)

É importante não perder de vista que a própria raiz grega eironeia indica dissimulação e interrogação, o que autoriza concluir que nas manifestações irônicas há uma divisão ou contraste de sentidos, e também um questionar ou julgar. Logo, estamos nos referindo a duas funções diferentes; todavia, vale assinalar que são também funções complementares.

O fragmento a seguir, retirado do romance Memórias póstumas de Brás Cubas, de Machado de Assis, constitui-se como exemplo profícuo dessa interdependência entre as duas funções da ironia comentadas aqui:

Talvez pareça excessivo o escrúpulo do Cotrim, a quem não souber que ele possuía um caráter ferozmente honrado. Eu mesmo fui injusto com ele durante os anos que se seguiram ao inventário de meu pai. Reconheço que era um modelo. Arguiam-no de avareza, e cuido que tinham razão; mas a avareza é apenas a exageração de uma virtude e as virtudes devem ser como os orçamentos: melhor é o saldo que o deficit. Como era muito seco de maneiras, tinha inimigos, que chegavam a acusá-lo de bárbaro. O único fato alegado neste particular era o de mandar com frequência escravos ao calabouço, donde eles desciam a escorrer sangue; mas, além de que ele só mandava os perversos e os fujões, ocorre que, tendo longamente contrabandeado em escravos, habituara-se de certo modo ao trato um pouco mais duro que esse gênero de negócio requeria, e não se pode honestamente atribuir à índole original de um homem o que é puro efeito de relações sociais.

Observando esse fragmento, é possível perceber que Machado de Assis fez uso da ironia a fim de realizar um julgamento negativo dirigido ao personagem Cotrim. Assim, partindo do nível semân- 
tico, temos nesse excerto a presença de inúmeros adjetivos atribuídos a essa personagem: uma pessoa de "escrúpulo excessivo", "de caráter ferozmente honrado", "um modelo", entre outras expressões.

Além disso, é interessante comentar a ocorrência de palavras como "único" e "só", respectivamente, em: "O único fato alegado neste particular era o de mandar com frequência escravos ao calabouço [...]" e "[...] além de que ele só mandava os perversos e os fujões [...]”. Fica claro que a intenção de Machado de Assis foi, no nível semântico, suavizar as atrocidades cometidas por essa personagem.

No entanto, faz-se necessário observar que a presença de muitos elogios aliada a essa tentativa de amenizar atitudes indiscutivelmente atrozes leva o leitor a inferir que está diante de uma atitude irônica por parte do narrador, que pretende, portanto, criticar e denegrir indiretamente a personagem Cotrim.

Como já se comentou em outros momentos deste livro, a participação do leitor na construção do sentido é imprescindível: um leitor desatento e passivo jamais chegaria a essas conclusões, uma vez que certamente não ultrapassaria o nível semântico do discurso desse narrador e, consequentemente, não acessaria o julgamento realizado por este.

Logo, nessa passagem de Memórias póstumas de Brás Cubas parte-se da função semântica e contrastante da ironia, para que se atinja sua função pragmática e avaliadora, fato que legitima a complementaridade entre essas importantes funções da ironia.

Há casos, porém, em que não há sinais de interdependência entre as funções da ironia estudadas aqui. A letra da canção transcrita abaixo, intitulada Heavy metal do senhor, do cantor e compositor Zeca Baleiro, demonstra bem esse comentário:

O cara mais underground que eu conheço é o diabo

que no inferno toca cover das canções celestiais com sua banda formada só por anjos decaídos a plateia pega fogo quando rolam os festivais 
enquanto isso Deus brinca de gangorra no playground do céu com santos que já foram homens de pecado de repente os santos falam "toca Deus um som maneiro" e Deus fala "aguenta vou rolar um som pesado" a banda cover do diabo acho que já tá por fora o mercado tá de olho é no som que Deus criou com trombetas distorcidas e harpas envenenadas mundo inteiro vai pirar com o heavy metal do Senhor

A letra dessa canção configura-se como um interessante caso de dissociação entre as funções semântica/contrastante e pragmática/ avaliadora da ironia. A fim de não beirarmos o radicalismo, digamos que há, nesse texto de Zeca Baleiro, uma ênfase maior na função contrastante da ironia.

Assim, de forma divertida e bem-humorada, o texto opõe as duas forças que, em nossa cultura, representam o bem e o mal Deus e o Diabo. Essa oposição, conforme se nota pela letra, se transforma numa competição musical. O mais interessante, no entanto - e é justamente nesse aspecto que reside a ironia -, é que ocorre uma inversão dos valores "bem" e "mal".

Desse modo, na primeira estrofe, ainda não observamos tal inversão, uma vez que as palavras "underground", "inferno" e "anjos decaídos" nos remetem - devido à forte influência da nossa cultura - a um campo semântico marcadamente negativo e relacionado ao "mal".

A partir da segunda estrofe, mais especificamente dos versos "de repente os santos falam 'toca Deus um som maneiro", e "Deus fala 'aguenta vou rolar um som pesado”, é possível observar o início da inversão; na verdade, as pessoas, de forma geral, motivadas pelos símbolos culturais que nos são transmitidos, não tendem a associar a ideia de Deus a um "som maneiro" ou a um "som pesado".

Aliás, é interessante perceber que, se o primeiro verso corresponde à fala dos santos - o que já seria "estranho" - o segundo verso corresponde à fala de Deus. A inversão nesse segundo verso é, pois, mais forte, porque a imagem de Deus imposta por nossa cul- 
tura se associa, invariavelmente, à ideia de paz, calmaria, harmonia e equilíbrio; sendo assim, imaginar que esse Deus, motivado pelos santos, tenha dito "aguenta vou rolar um som pesado", chega a ser divertido e essa sensação provém justamente de uma quebra de expectativas ou de uma inversão no plano semântico.

No sentido em que encaminhamos a análise, a terceira estrofe é surpreendente:

a banda cover do diabo acho que já tá por fora

o mercado tá de olho é no som que Deus criou

com trombetas distorcidas e harpas envenenadas

mundo inteiro vai pirar com o heavy metal do Senhor.

Nela, Deus desbanca o Diabo utilizando em sua banda "trombetas distorcidas" e "harpas envenenadas". Aqui, a inversão é ainda mais explícita, já que a esses instrumentos musicais - trombetas e harpas - geralmente são associadas as ideias de paz e de tranquilidade. No caso da letra de Zeca Baleiro, todavia, as trombetas são "distorcidas" e as harpas, "envenenadas", o que sugere um som diferente, especial e alterado.

Logo, se no início da disputa entre esses paradigmas do Bem e do Mal, o Diabo leva a melhor "tocando cover das canções celestiais" (primeira estrofe), a partir da segunda estrofe, Deus vence a disputa, fazendo uso das "técnicas" mais associadas à ideia que se faz do Diabo.

Como se vê, há uma forte inversão semântica que se dá já a partir do título da canção, bastante significativo, nesse sentido: "Heavy metal do senhor". Portanto, o que ocorre é, de fato, uma espécie de "cruzamento" de valores: a figura do Diabo assume os valores de seu opositor, digamos assim, e o estereótipo do Bem - Deus - toma para si características atribuídas em geral à ideia do "Mal".

Obviamente, todo esse contraste semântico pode conduzir o leitor a uma ou a várias possibilidades de julgamento, e, nesse sentido, teríamos também presente nessa composição a segunda função da ironia aqui estudada: aquela que designamos pragmática ou ava- 
liadora. Entretanto, mesmo assim, é preciso ficar claro que existe uma ênfase maior na função contrastante da ironia, como tentamos demonstrar.

Portanto, é pertinente dizer, sobre as funções mais importantes da ironia aqui examinadas, que há, como vimos, uma interdependência entre elas e que, geralmente, a função semântica contrastante conduz à função pragmática avaliadora. Todavia, em determinados discursos, de acordo com a intencionalidade de seus produtores, salienta-se mais uma das duas funções.

Assim, no caso do excerto de Memórias póstumas de Brás Cubas, o "projeto" daquele narrador naquele instante específico era antes de tudo denegrir a imagem daquela personagem; já na composição de Zeca Baleiro, percebe-se a intenção primeira de inverter, de misturar valores. Isso nos autoriza a concluir, por exemplo, que seu autor pretendeu dizer que a "boa música", a fim de agradar a todos, deve ser resultado da "contaminação" ou do diálogo entre todos os ritmos e tendências musicais, ainda que sejam opostos. Logo, no excerto de Machado, predomina a função avaliadora da ironia e, na canção de Zeca Baleiro, a função contrastante.

Para além das funções semântica contrastiva e pragmática avaliadora, existem outras também muito importantes e que, de certo modo, derivam das duas primeiras funções apontadas neste trabalho. Queremos dizer justamente que as funções que serão comentadas agora - todas elas - se encaixam num desses dois grandes grupos: ou tendem mais para a ironia de característica semântica contrastiva ou para a função pragmática avaliadora da ironia.

É importante dizer ainda que o estudo dessas funções específicas da ironia se justifica na medida em que nos aproxima muito de uma definição mais exata sobre o conceito de ironia. Assim, Linda Hutcheon, em Teoria e política da ironia, alista nove funções para a ironia, partindo daquela que possui uma carga afetiva mínima e caminhando para a função em que se expressa carga afetiva máxima.

É interessante notar também que Hutcheon comenta duas interpretações opostas provenientes do uso de cada função. Em outras palavras, na opinião dessa estudiosa, a opção por uma ou por 
outra função da ironia sempre possibilita, no mínimo, duas interpretações, que se manifestarão de acordo com o interpretador.

Seguindo esse raciocínio, partimos analisando a primeira função da ironia: reforçadora. Nesse caso, ela serve para salientar algo; por exemplo, na conversação cotidiana, para enfatizar um enunciado, tornando-o mais preciso. Como foi dito, a posição desaprovadora nessa mesma função, ou seja, a interpretação que contradiz a primeira, o faz porque acredita que essa ironia reforçadora é puramente decorativa e subsidiária.

A próxima função é a complicadora, aquela que insere os discursos irônicos no rol dos discursos verdadeiramente artísticos, caracterizados por uma ambiguidade controlada e avaliada, que nos chama para a reflexão e, em consequência, para sua interpretação. As conotações negativas acerca dessa função não faltam, uma vez que muitos acreditam ser essa complexidade da ironia desnecessária. Segundo Hutcheon, na opinião desses interpretadores,

a ambiguidade pode gerar incompreensão, confusão ou simplesmente imprecisão e falta de claridade na comunicação. E isso, realmente, é o que provoca a irritação daqueles que sentem ou são levados a sentir que "perderam" ironias. (2000, p.78)

Como se vê, nem todos são atraídos pela beleza dos discursos ambíguos e incongruentes. A outra função da ironia é a função lúdica. Ela pode ser entendida como caracterizadora de uma ironia afetuosa de provocação benevolente, podendo estar associada também ao humor. As inferências contrárias também marcam esse tipo de manifestação irônica: essa função faz da ironia um tipo de discurso irresponsável, vazio e tolo, que não oferece, portanto, nada importante e, além disso, "banaliza a seriedade essencial da arte" (2000, p.70).

A função distanciadora da ironia é a seguinte a merecer nosso comentário. A ironia, quando assume essa função, permite que o ironista e mesmo o interpretador da ironia se afastem, se distanciem de uma dada situação a fim de olhá-la sob uma nova perspectiva. As 
interpretações mais pejorativas relacionadas a essa função consideram que ela instaura a indiferença e, consequentemente, um ar de superioridade naqueles que fazem uso desse tipo de ironia.

Na verdade, como foi visto no início deste livro, perceber incongruências e ambiguidades e olhar os fatos que nos rodeiam sob uma ótica nova apenas alargam de forma impressionante a visão, permitindo que o sujeito recuse a tirania dos discursos monológicos e dos julgamentos explícitos.

A quinta função da ironia é a autoprotetora. Nesse caso, a ironia pode ser interpretada como uma espécie de "mecanismo de defesa". Até mesmo a autodepreciação pode nessas situações ser fingida, resultando em uma forma de autopromoção. Logo, a autodepreciação pode ser interpretada como uma jogada defensiva também. Segundo Hutcheon,

para o ironista, a ironia significa nunca ter de se desculpar. Você pode sempre se proteger e argumentar (de uma perspectiva de intenção) que você estava apenas sendo irônico. Você pode até mesmo transformar um erro numa piada com a mesma declaração; você com certeza pode usá-la para sair de qualquer situação embaraçosa. Usar ou mesmo atribuir ironia dessa maneira é recorrer à sua função de "veste protetora". (2000, p.81)

A sexta função, muito interessante, é a provisória. A ironia que se manifesta tendo em vista essa função desmistifica verdades absolutas solapando, consequentemente, quaisquer dogmatismos. As investidas desaprovadoras aqui se baseiam na interpretação de que essa função da ironia instaura a possibilidade da evasão, da hipocrisia, da duplicidade e do logro.

Hutcheon, remetendo-se aos significados de ironia fornecidos pelo Oxford English Dictionary, encontra as seguintes definições: "um ato deliberadamente enganador que sugere uma conclusão oposta à real" e "ironia significa enganar pessoas comuns que entendem de maneira comum" (apud Hutcheon, 2000, p.81). Hutcheon, citando H. M. Chevalier, afirma: 
É esse caráter provisório indeciso que configura a ironia como a atitude de alguém que, quando confrontado com a escolha de duas coisas que são mutuamente exclusivas, escolhe ambas. O que é uma outra maneira de dizer que ele não escolhe nenhuma delas. Ele não consegue desistir de uma pela outra e ele desiste de ambas. Mas ele se reserva o direito de obter de ambas o máximo de prazer passivo possível. E esse prazer é a ironia. (Chevalier, 1932, p.79, apud Hutcheon, 2000, p.82)

As interpretações positivas acerca dessa função valorizam a duplicidade da ironia, vista como uma maneira de neutralizar quaisquer tendências a assumir um posicionamento rígido ou categórico de "verdade". Voltemos mais uma vez a Linda Hutcheon:

Esse é um funcionamento da ironia que não rejeita ou refuta ou vira de cabeça para baixo: não é evasão ou falta de coragem ou convicção, mas uma admissão de que há ocasiões em que não conseguimos ter certeza, não tanto porque não sabemos o suficiente quanto porque a incerteza é intrínseca, essencial. (2000, p.82)

Portanto, como se pôde perceber, posicionamentos opostos relacionados ao mesmo "objeto": a função provisória da ironia.

A função seguinte é a de oposição da ironia. Por meio dela, a ironia é vista e interpretada, por um lado, como transgressora e subversiva, e, por outro, como insultante e ofensiva. Aqui, mais uma vez, nos aproximamos do interpretador da ironia, pois, aquilo que alguns aprovam como transgressor, pode simplesmente ser insultante e ofensivo para outros.

Linda Hutcheon designa a função seguinte de atacante. Segundo Hutcheon,

A carga negativa aqui chega ao máximo quando uma invectiva corrosiva e um ataque destrutivo tornam-se as finalidades inferidas - e sentidas - da ironia. Em muitas discussões sobre a ironia, essa parece ser a única função que se leva em conta, especialmente quando a questão é de apropriabilidade ou, principalmente, de excesso no seu uso. (2000, p.83) 
Hutcheon chama a atenção, todavia, para o fato de que a ironia possui também, como já foi comentado neste trabalho, uma função corretiva, sobretudo quando ela é utilizada pela sátira. Assim, quando a ironia assume a função atacante, haveria, então, uma "motivação positiva" (Hutcheon, 2000, p.84) para que uma crítica tão agressiva fosse realizada: a finalidade de corrigir os vícios e as loucuras da humanidade.

Há, como nas outras funções, juízos pejorativos relacionados a essa "função atacante". Aqui, a ironia é desaprovada na medida em que é vista como um meio de humilhação agressiva e como uma necessidade de registrar desprezo e zombaria. Para os críticos que pensam dessa maneira, o desejo de desprezar e humilhar estaria muito acima do de corrigir.

Finalmente, a última função da ironia: a agregadora. Nesse tipo de manifestação, a ironia motiva também interpretações contraditórias: num sentido positivo, cria "comunidades amigáveis" entre ironista e interpretador; no sentido negativo, exclui aqueles que não a compreendem ou, como disse Hutcheon (2000, p.86), que não a "pegam", impedindo-os de participarem dessas comunidades. De acordo com essa estudiosa,

Num sentido negativo, diz-se que a ironia joga para grupos fechados que podem ser elitistas e excludentes. A ironia claramente diferencia e assim potencialmente exclui [...] Alguns teóricos sentiram que qualquer distanciamento irônico implica o dualismo superioridade/ inferioridade. [...] Essa ideia da ironia funcionando de uma maneira obviamente elitista envolve uma inferência sobre ambos o ironista (que se sente superior) e o interpretador (que "pega" a ironia) e assim sente-se parte de uma sociedade pequena, seleta e secreta. Como isso sugere, no entanto, a ironia que exclui também inclui, criando aquelas "comunidades amigáveis" [...] e, dessa forma, relembrando os prazeres da colaboração [...] (2000, p.86, grifos nossos)

Para Hutcheon, essa função expressa carga crítica e emotiva máxima, já que é a que mais obviamente favorece a arrogância e a 
insensibilidade, envolvendo-se de modo íntimo com as questões de poder e de autoridade.

Conforme tentamos demonstrar, a ironia, além de se originar da sobreposição de vozes antagônicas, provoca sensações também contraditórias a partir do momento em que ocorre. Logo, a ironia se dá não apenas no momento em que é localizada a dissonância inerente a um discurso; ela permanece reverberando nos efeitos tão díspares que provoca naqueles que a desvendam. 


\section{3 \\ PARÓDIA}

Através da paródia, o escritor quebra com os padrões estabelecidos e nos força a reconhecer a persistência de uma outra forma de ficção. Na tensão entre a ficção passada e a nova, sobressai o poder de renovação do homem, que insiste em não se deixar dominar por nenhuma Força.

Maria Lucia P. de Aragão

A paródia, definida etimologicamente como "canto paralelo", embora se faça bastante presente nos textos literários da modernidade, também coroou momentos literários cronologicamente distantes. A estudiosa Maria Lucia P. de Aragão, a fim de chegar a uma definição mais precisa do conceito de paródia, faz uma reflexão muito interessante sobre o papel da arte literária.

De acordo com ela, há uma estrutura ideológica que, por meio da discursividade, inverte o real tomando o seu lugar, ou seja, fazendo-se passar por ele. Assim, para Aragão,

Se considerarmos o fato de que a ideologia, como é comumente definida, consiste na representação de uma estrutura de relações histó- 
ricas, num período social, economicamente dado, veremos que, num primeiro momento, esta visão epocal, historiográfica e periodizada imagina-se proprietária da verdade e busca ampliar o seu ilusório domínio por todo o acontecimento histórico. A ideologia, pois, nesse sentido, é uma falsa consciência da História, porque se situa nos limites de uma verdade parcial, e a verdade é dinâmica no seu processar-se. (1980, p.18-9)

Lucia Helena (1980, p.73-4), crítica e ensaísta, também aborda de maneira muito interessante essa questão:

Primeiramente o modelo maniqueísta, com que operam as normas sociais em nossa cultura, apreende a realidade a partir de esquemas mentais inconciliáveis e bipolarizados. Eis aí um terreno fértil para a ideologia da seriedade que, colocando-se "acima", como figuração do espaço do poder, determina o válido, o permitido, o belo, assim como condena e exorciza o que lhe é marginal ou contestador. A ideologia da seriedade opera por um tratamento sisudo e bem comportado, além de selecionar um repertório nobre [...] De tal modo que o cotidiano, a impureza, o vício estão longe de seu interesse e frequentam uma espécie de "index probi". [...] Se a ideologia da seriedade faz uso do riso, é um uso previsto, intencionalmente catártico e regulador do sistema. [...] É uma apropriação nostálgica do riso, que perde sua função corrosiva e crítica, por ser consumido de modo anestésico.

Como se pode perceber, ao passo que há uma ideologia manipuladora disfarçada em realidade - que manipula até mesmo o riso conforme seja conveniente -, o discurso literário existe justamente para subverter esse estado de coisas: ele realiza com a estrutura ideológica o que esta realizou com o real. Em outras palavras, o discurso literário inverte a estrutura ideológica, rompendo modelos socialmente impostos e provocando, pois, o questionamento. Também para Maria Lucia Aragão,

A obra literária, por ser uma inversão dos códigos estabelecidos, por questionar a ideologia do modo como ela se apresenta, por ser menos 
setorial, faz aparecer o que se esquivou no conceito superficial. O literário, por ser um fenômeno, ilumina o que a ideologia, por si mesma, não tem condições de mostrar. Ele opera uma variação sobre a realidade. Reconstrói um outro sistema, a partir de uma ruptura com o sistema ideológico vigente, provocando o questionamento. (1980, p.19)

De maneira semelhante, a paródia, segundo essa estudiosa, também tem a função de problematizar, inverter e questionar até mesmo o modelo literário sobre o qual se estabelece - uma vez que, se já se tornou um "modelo literário", não deixa de ser também uma estrutura ideológica.

Seguindo esse raciocínio, o parodiador é aquele que percebe a necessidade de novas "verdades" em seu meio cultural; sente, pois, que os moldes seguidos em sua época precisam ser questionados e substituídos. Esse momento de percepção da carência de algo novo e de certeza de que os modelos literários e ideológicos atingiram seu limite de saturação é, justamente, o momento da paródia. Para Maria Lucia Aragão,

Nesta recusa em aceitar os modelos literários vigentes ou os mitos, ou os procedimentos, ou melhor, tudo aquilo que compõe o acervo cultural de sua época, o parodiador está denunciando a sua preocupação com os elementos que servem a esta estrutura já esgotada, que é preciso esvaziar, para poder preencher com algo novo. Por vezes a paródia fica camuflada sob certos tipos de disfarces, nos quais não percebemos, de imediato, a intenção do autor. Geralmente, o recurso de falar de outras épocas, de culturas ultrapassadas, é empregado como crítica à ideologia vigente em sua própria época. (1980, p.19)

Uma vez que se está apresentando a paródia como espécie de recusa, faz-se importante notar que ela não se trata de um tipo de discurso niilista, caracterizado por uma crítica vazia, desconstrucionista e cética. O parodiador, muito ao contrário, preocupa-se com a sua época, enxerga-lhe as lacunas e sugere novas ideias por meio de um "canto paralelo" - paralelo exatamente porque deslocado da já então gasta ideologia vigente. 
Outro traço bastante expressivo da paródia é que, constituindo- se como discurso artístico - uma vez que não é restrita ao âmbito literário -, não traz respostas prontas a seus questionamentos. $\mathrm{Na}$ verdade, constitui-se como pretensão significativa de um texto paródico - após a pretensão primeira, que é ser reconhecido como paródico - convidar o leitor à reflexão, provocando um crescimento ilimitado, na medida em que coloca o modelo em aberto. Na opinião de Aragão,

Parodiar é recusar e esvaziar, é dessacralizar sem descrer, pois só se discute e se leva em consideração aquilo em que se acredita. A paródia possui um caráter positivo, pois mata para fazer brotar novamente a criação. Recusa e esvazia o modelo original para recriar e preencher um modelo que lhe é próprio. (1980, p.20)

A ligação estreita entre paródia e carnavalização deve também ser mencionada. Para Bakhtin, o procedimento paródico é uma das formas de carnavalização. Fica fácil entender tal relação quando se pensa na visão carnavalesca do mundo enquanto oposição absoluta ao sério, ao monológico e ao dogmático, que, de acordo com Lucia Helena (1980, p.20), são - o sério, o monológico e o dogmático "engendrados pelo medo, inimigo do vir a ser e das mudanças, e responsável pela tendência à absolutização do estado de existência das coisas e da ordem social."

Em Problemas da poética de Dostoievski, Bakhtin - para quem a paródia é um elemento inseparável dos gêneros carnavalizados afirma, sobre a carnavalização:

A carnavalização não é um esquema externo e estático que se sobrepõe a um conteúdo acabado, mas uma forma insolitamente flexível de visão artística, uma espécie de princípio heurístico que permite descobrir o novo e inédito. Ao tornar relativo todo o exteriormente estável, constituído e acabado, a carnavalização, com sua ênfase das sucessões e da renovação, permite penetrar nas camadas profundas do homem e das relações humanas. (1981, p.144-5) 
No entanto, é preciso atentar para o fato de que nem sempre a simples presença da paródia garanta a carnavalização, uma vez que a cosmovisão carnavalesca tem sempre um sentido desmistificador - traço facultativo para a irrupção da paródia. Para Maria Elena Pinheiro Maia,

(A visão carnavalesca) subverte os valores tradicionais e propõe-nos uma visão mais crítica do mundo, questionando as verdades impostas para convencer e conduzir o próprio homem. A carnavalização nos proporcionará a possibilidade de estudar a dialética da própria vida. E essa visão dupla nos parece muito mais verdadeira do que aquela visão autoritária que conhecemos através da história oficial. $\mathrm{O}$ carnaval representa, assim, a intertextualidade de ideologias oficiais e não oficiais. (1999, p.19)

Para M. Bakhtin, "a paródia carnavalesca é a paródia dialógica e não uma simples negação pobre do parodiado” (1981, p.109). Vista dessa maneira, a paródia é ambivalente, joga com diferentes imagens que se parodiam umas às outras de diversas maneiras e sob diferentes pontos de vista. Observaremos tais efeitos de sentido em O cavaleiro inexistente, de Ítalo Calvino.

Logo, constituindo-se a paródia, na visão bakhtiniana, como uma das formas de carnavalização, torna-se evidente a relação entre essas categorias: ambas desafiam e subvertem os dogmas e os discursos oficiais, propondo "vozes culturais" diferentes, polifônicas.

Como se sabe, a teoria proposta por Bakhtin divide os discursos em monológicos e dialógicos. Os primeiros seriam aqueles transmissores de formas de expressão oficiais ou sérias; os segundos seriam "manifestações mais rudes, carnaval ou farsa, em geral ignoradas ou desprezadas pelos críticos e pelos pesquisadores" (Hayman, 1980, p.30). O carnaval e a paródia configuram-se, por conseguinte, como formas dialógicas.

Maria Lucia Aragão compara a paródia a um tipo de visão especular na qual a imagem original se encontra invertida, ampliada ou reduzida, de acordo com a lente utilizada, ou seja, conforme as in- 
tenções do parodiador. Graças a esse jogo de espelhos, o sentido em um texto paródico nunca é definitivo, uma vez que apresenta diversas possibilidades de leitura. De acordo com essa estudiosa,

A narrativa paródica não é construída mecanicamente, como se sua função fosse a de descrever o velho sistema, num reflexo paralelo. Através de um jogo de espelhos inclinados, que produz imagens sob vários ângulos, é revelado um novo e significativo mundo. O escritor usa de artifícios que possibilitam a retomada de uma narrativa como uma dissimulação, ou melhor, através do projeto de uma estilização paródica da ideologia de uma determinada época, reconduz o texto a uma crítica dessa ideologia. Fala do velho para falar do novo. Recua no tempo para deixar o tempo avançar. (1980, p.22)

Desse modo, a paródia, tencionando a fuga do lugar-comum, põe em confronto uma multiplicidade de visões, uma vez que, como escrita da ruptura, objetiva um corte com os modelos anteriores, retomando-os de maneira invertida, destruindo para construir. Assim, a paródia reproduz um choque e deve, pois, ser fruto de uma diferença de postura entre dois planos. Tal choque, como já foi dito no início deste livro, deve ser percebido pelo leitor, elemento central desse tipo de texto literário.

Outro aspecto interessante da paródia é que, contendo outro texto em si, ela geralmente fala sobre o que esse outro texto deixou de dizer e salienta o fato de não ter sido dito. Para Flávio Kothe (1980, p.98), portanto,

A paródia é um texto duplo, pois contém o texto parodiado e, ao mesmo tempo, a negação dele. Ela é, portanto, a síntese de uma contradição, dando prioridade para a antítese, em detrimento da tese proposta pelo texto parodiado.

Bella Jozef (1980, p.69) chega a algumas conclusões relacionadas ao conceito de paródia: 
1. A paródia dilata o alcance do signo literário, produzindo um novo corte semântico do signo para além da superfície manifesta do texto que a produz e que ela, simultaneamente, reproduz.

2. É uma escrita transgressora, que revela na obra um segundo plano discordante.

3. Esclarece o funcionamento intertextual, ao atuar como reflexão crítica sobre o processo de composição.

4. Estabelece os princípios dinâmicos fundamentais do texto, aprofundando seu mecanismo.

5. Representa a subversão de toda temática e sua essência revela-se na escrita e pela escrita.

6. A paródia apresenta o processo de produção do texto.

Entre as conclusões a que chega Bella Jozef, a relação que fica sugerida entre a paródia e a ironia romântica nos itens terceiro e sexto é, sem dúvida, o que mais chama atenção. Voltaremos a essa questão tão importante para a presente pesquisa no capítulo 5 , onde trataremos justamente das relações entre ironia, paródia e riso.

É preciso comentar, por ora, que alguns autores realizam uma distinção entre a paródia e o que se convencionou chamar estilização. Entre eles, Flávio Kothe, em uma análise de certo modo radical, situa a primeira numa escala inferior em relação à segunda. Ele diz o seguinte:

a paródia existe completamente à sombra daquilo a que ela parodia, enquanto que a estilização segue um caminho próprio que a independiza. A paródia existe apenas como antítese e como negação determinada; a estilização constitui uma síntese que supera aquilo a que ela nega e preserva modificadamente. Há uma diferença qualificativa entre ambas: a paródia tende a cair num nível artístico mais ou menos baixo, enquanto que a estilização procura galgar o topo da pirâmide artística. Por isso mesmo, há uma diferença quantitativa entre as duas: as paródias são muito mais frequentes e fáceis do que as estilizações. A estilização é uma paródia que deu certo como arte maior. (1980, p.99-100) 
$\mathrm{Na}$ verdade, se a paródia se define pela tensão que expressa entre o que diz e o texto parodiado, não parece coerente falar em independência da paródia em relação ao texto primeiro. Seguindo esse raciocínio, a paródia nem poderia, como a estilização, "seguir um caminho próprio", pois se caracteriza justamente pelo diálogo que trava com o texto parodiado, não havendo razões, portanto, para tornar-se independente dele.

Segundo Hutcheon, "a paródia precisa de quem a defenda, pois tem sido designada de parasitária e derivativa" (1985, p.14). Ao que parece, não somente Flávio Kothe tem colocado a modalidade aqui analisada em uma posição inferior em relação às outras artes. Esses ataques à paródia revelam aversão e desprezo direcionados a um gênero - que permeia toda a arte - com intenções explícitas de denegri-lo.

As ideias de Linda Hutcheon vêm ao encontro daquelas defendidas por este livro; não há como negar que, por meio de investidas desse tipo, esses críticos acusam os parodistas de serem inimigos da originalidade. Para essa estudiosa, "o que se torna claro com esse tipo de ataques é a força subsistente de uma estética romântica que aprecia o gênero, a originalidade e a individualidade" (1985, p.14).

Todavia, é preciso considerar que escritores românticos de renome como Camilo Castelo Branco, em Portugal, e Álvares de Azevedo, no Brasil, criaram textos paródicos e nem por isso deixaram de ser considerados "gênios" ou se viram desprovidos de sua originalidade. Além disso, conforme foi dito anteriormente, a ironia romântica - que mantém relações estreitas com a paródia, como se estudará mais adiante - esteve muito presente em textos literários dos séculos XVIII e XIX. Essas constatações nos autorizam concluir que os próprios românticos não tinham tanta aversão assim à paródia.

Odil de Oliveira Filho propõe uma definição mais interessante, visto que define essas categorias - a paródia e a estilização - sem se preocupar em sobrepô-las: 
O caráter conciliador da estilização não subsiste na paródia. Aqui, a segunda voz, uma vez instalada no discurso do outro, entra em hostilidade com seu agente primitivo e o obriga a servir a fins diametralmente opostos, e o discurso se converte em palco de luta de duas vozes. Por isso diz Bakhtin ser impossível a fusão de vozes na paródia, como o é possível na estilização, pois nela as vozes não são apenas isoladas, separadas pela distância, mas estão em oposição hostil. (1993, p.48)

Como é possível notar, Odil não prioriza a estilização em relação à paródia, todavia, sugere a "oposição de vozes" como marca inerente apenas à paródia. Linda Hutcheon alarga, entretanto, o conceito da categoria aqui estudada. De acordo com ela, a raiz etimológica do termo vem do substantivo grego parodia, que não quer dizer apenas "contracanto", como se afirma entre a maioria dos teóricos. O elemento odos da palavra significa canto, no entanto, o prefixo para tem dois sentidos em grego: um, mais comum, que é o de "contra" ou "oposição" e o outro, que é o sentido menos citado, de "ao longo de". Essa segunda significação sugere, como se vê, um acordo ou intimidade ao invés de um contraste. Logo, no entender de Linda Hutcheon,

Mesmo em relação à estrutura formal, o caráter duplo da raiz sugere a necessidade de termos mais neutros para a discussão. Nada existe em parodia que necessite da inclusão de um conceito de ridículo, como existe, por exemplo, na piada, ou burla, do burlesco. A paródia é, pois, na sua irônica "transcontextualização" e inversão, repetição com diferença. Está implícita uma distanciação crítica entre o texto em fundo a ser parodiado e a nova obra que incorpora, distância geralmente assinalada pela ironia. (1985, p.48)

A não necessidade de um contraste ou oposição entre as vozes do texto parodiado e as do "segundo" texto é, de fato, uma característica pouco considerada entre os críticos. Essa questão será aprofundada mais adiante na próxima seção deste capítulo.

Como foi possível perceber, definir a paródia não é uma tarefa muito simples, já que se trata de uma modalidade bastante com- 
plexa. Tentamos mostrar também que muitos críticos se debruçaram sobre essa intrigante categoria literária, porém poucos realizaram com pertinácia seu intuito. Sendo assim, buscando explicações mais apropriadas sobre a paródia, realizaremos, primeiramente, o estudo da paródia como "canto paralelo" - em oposição ao conceito de "contracanto" - e, em seguida, no capítulo 5, faremos paralelos entre essa categoria - a paródia - e outras, cujos "mecanismos de construção" são semelhantes.

\section{O paradoxo da paródia}

Como foi dito anteriormente, a paródia não deve ser vista sempre como uma categoria que visa à desconstrução e à ridicularização de discursos anteriores. Na verdade, segundo a estudiosa Linda Hutcheon, a paródia se caracteriza por uma "voz" que se propõe a repetir de forma crítica, assinalando, desse modo, um discurso que marca a diferença em vez da semelhança. Assim, a crítica não tem de estar necessariamente presente na forma de riso ridicularizador para que um texto seja considerado paródia.

Seguindo, pois, uma definição mais abrangente e menos comum, a paródia - distanciada da visão tradicional de "canto ridicularizador" - funciona, ao contrário, como uma inscrição de continuidade histórico-literária, atuando na revisão crítica de discursos anteriores. Segundo Linda Hutcheon, "talvez os parodistas não façam mais do que apressar um processo natural: a alteração das formas estéticas através do tempo" (1985, p.51). Ainda para essa estudiosa,

A paródia é, pois, tanto um ato pessoal de suplantação, como uma inscrição de continuidade histórico-literária. Daí surgiu a teoria dos formalistas acerca do papel da paródia na evolução ou mudança das formas literárias. A paródia era vista como uma substituição dialética de elementos formais cujas funções se tornaram mecanizadas ou automáticas. Neste ponto, os elementos são "refuncionalizados" [...] Uma nova forma desenvolve-se a partir da antiga, sem na realidade a des- 
truir; apenas a função é alterada. [...] A paródia torna-se, pois, um princípio construtivo na história literária. (1985, p.52)

Uma vez considerada a paródia como uma categoria que possibilita a revisão crítica de discursos históricos e literários, promovendo, consequentemente, a manutenção desses mesmos discursos, chega-se a uma interessante contradição: a paródia, ao mesmo tempo que "põe em xeque" alguns modelos, transgredindo-os, acaba reforçando, legitimando tais modelos.

Faz-se interessante aqui, mais uma vez, retomar a ideia de carnaval proposta por Bakhtin. Ao explicar esse conceito, o estudioso citado esbarra em um princípio caracterizador de todo discurso paródico: o paradoxo da transgressão autorizada das normas.

Assim, o carnaval, que caracteriza as festas populares de maneira geral e marcou também as famosas festas gregas, embora aconteça por meio da subversão de todas as regras consagradas pela tradição - sejam elas oficiais, religiosas ou políticas -, confirma, paradoxalmente, essas mesmas regras. Conforme Minois explica,

[As festas] asseguram a perpetuação da ordem humana, renovando o contato com o mundo divino; e o símbolo do contato estabelecido com o divino é o riso, que, como vislumbrado pelos mitos, é um estado de origem e de iniciativa divina, comparável, em certos casos, ao transe. (2003, p.30)

Por conseguinte, é possível afirmar que o riso festivo, visto dessa forma, seja uma maneira de manifestar um contato com o mundo divino, uma vez que ele (o riso) simula o retorno ao caos original que precedia a criação do mundo ordenado. Minois ilustra esse raciocínio:

A inversão segue o mesmo rumo. Durante a festa Krônia, os escravos desfrutavam grande liberdade, podiam até fazer-se servir pelos senhores, que eles repreendiam. Bem no meio dos risos, zombarias e brincadeiras obscenas. O caos é indispensável para representar, em se- 
guida, a criação da ordem. Durante essas desordens em que o riso é livre, escolhe-se um personagem que preside e encarna esse caos, um prisioneiro ou um escravo que vai ser sacrificado no fim da festa, para um ato fundador da regra, da norma, da ordem. [...] Depois de sua morte, tudo retornava à ordem, o riso livre desaparecia. (2003, p.31)

Logo, a anarquia e o caos plenos, que questionam com veemência a legitimidade de algumas convenções impostas pela sociedade, colaboram, contraditoriamente, para a recriação do mundo ordenado e para o reforço periódico da regra. Trata-se, pois, no caso dessas festas gregas, do avesso do cotidiano, da ruptura com as atividades sociais e do abandono de quaisquer convenções - traços inerentes ao carnaval bakhtiniano, que instituem, de maneira paradoxal, a ordem. Ocorre algo bastante semelhante com a paródia:

As transgressões da paródia permanecem, em última análise, autorizadas - autorizadas pela própria norma que procura subverter. Mesmo ao escarnecer, a paródia reforça; em termos formais, inscreve as convenções escarnecidas em si mesma, garantindo, consequentemente, a sua existência continuada. É neste sentido que a paródia é o guardião do legado artístico, definindo não só onde está a arte, mas de onde ela veio. Ser um guardião, todavia, [...] pode ser uma posição revolucionária; a questão é que não precisa de o ser. (Hutcheon, 1985, p.97)

Como se percebe, a paródia não deixa de ser, nesse sentido, um tipo de discurso carnavalesco, na medida em que, subvertendo modelos confirmados pela tradição, acaba por reforçá-los. Ainda de acordo com Linda Hutcheon,

O reconhecimento do mundo invertido exige ainda um conhecimento da ordem do mundo que inverte e, em certo sentido, incorpora. A motivação e a forma do carnavalesco derivam ambas da autoridade: a segunda vida do carnaval só tem sentido em relação com a primeira vida oficial. (1985, p.95) 
Assim também ocorre com a paródia: o texto que parodia apenas tem sentido se o leitor encontra em seu cerne vestígios do texto parodiado. Seguindo esse raciocínio, a paródia colabora para a revalorização dos textos que parodia. Está justamente aí o seu paradoxo: o ato de parodiar - caracterizado pela análise crítica de discursos anteriores e, muitas vezes, por uma atitude de escárnio por parte do parodiador - reveste esses discursos parodiados de importância, estabelecendo, pois, a sua continuidade. Para Hutcheon, mais uma vez:

Este paradoxo da subversão legalizada, embora não oficial, é característica de todo discurso paródico na medida em que a paródia postula, como pré-requisito para a sua própria existência, uma certa institucionalização estética que acarreta a aceitação de formas e convenções estáveis e reconhecíveis. Estas funcionam como normas ou regras que podem ser - e logo, evidentemente, serão - quebradas. Ao texto paródico é concedida uma licença especial para transgredir os limites da convenção, mas, tal como no carnaval, só pode fazê-lo temporariamente e apenas dentro dos limites autorizados pelo texto parodiado - quer isto dizer, muito simplesmente, dentro dos limites ditados pela reconhecibilidade. (1985, p.96)

Por conseguinte, como se pôde notar, o texto parodiado sempre é valorizado e perpetuado, mesmo quando está presente uma atitude notadamente trocista por parte do parodiador. Isso ocorre porque, como se sabe, a intenção de questionar, atacar ou denegrir o que quer que seja oculta, na verdade, o valor e a importância conferidos pelo crítico aos "objetos" de sua crítica. A paródia caminha, pois, da crítica contundente e por vezes escarnecedora à valorização implícita dos conteúdos parodiados. 



\section{4 \\ O RISO}

O riso é a sabedoria, e filosofar é aprender a rir.

Sem a liberdade de rir, de caçoar e fazer humor, não há progresso da razão.

Georges Minois

O presente capítulo debruça-se sobre um ato humano extremamente vago e fugidio: o riso. Entre as inúmeras e variadas análises que foram realizadas sobre ele por pensadores e teóricos - análises estas que percorreram todos os séculos desde a Antiguidade - escolhemos aquela que consideramos mais abrangente e clara, além de vir ao encontro dos propósitos que interessam a esta pesquisa: o riso como uma possibilidade de alargar o conhecimento, propondo novas formas de se olhar para o mundo.

Nesse sentido, temos o riso como um ato ligado ao perímetro "não oficial" da sociedade, ou seja, ao âmbito dos discursos ou atitudes que de algum modo fogem do padrão e do regrado. Seguindo esse raciocínio, explica Verena Alberti:

O riso revelaria assim que o não-normativo, o desvio e o indizível fazem parte da existência. [...] São inúmeros os textos que tratam o riso no contexto de uma oposição entre a ordem e o desvio, com a conse- 
quente valorização do não-oficial e do não-sério, que abarcariam uma realidade mais essencial do que a limitada pelo sério. (1999, p.12)

Portanto, como foi dito na "Introdução", o riso será tratado aqui sobretudo como um tipo de discurso que instaura, em vez da certeza, a possibilidade; em lugar do uníssono, o ambivalente; em vez do maniqueísmo, a tensão e o elemento instável.

Outro aspecto relevante é a proximidade entre as manifestações do riso, da paródia e da ironia, modalidades que compartilham, quase sempre, a função de questionar as certezas, as verdades absolutas, as rígidas divisões entre certo e errado - enfim, de questionar o modelo maniqueísta, seja ele qual for. Resulta daí a presença de tensão ou de elementos dissonantes tanto no riso quanto na paródia e ironia.

Como dissemos, existem análises as mais variadas a respeito do riso, o que nos obriga a apresentar aqui um rápido esboço delas, procurando seguir uma ordem cronológica. Após esse breve passeio por diferentes teorias, voltaremos a falar do riso em seu caráter contraditório e incongruente, visitando com mais vagar estudiosos cujas teorias contemplam as indagações mais importantes para nossa investigação.

\section{De Aristóteles a Schopenhauer}

É possível encontrar a busca de uma definição do riso já nas teorias da Antiguidade, em obras como Filebo e A República, ambas de Platão, e na Poética, de Aristóteles. Em Platão, o risível é definido como um vício que se opõe à sugestão do oráculo de Delfos, que afirma: "conhece-te a ti mesmo". Assim, aquele que desconhece a si mesmo, acreditando, por exemplo, ser mais do que, de fato, é torna-se risível.

Além disso, a segunda "condição" do risível, para Platão, é que o indivíduo que não se conhece seja também fraco. Conforme Verena Alberti comenta, 
Poder-se-ia falar aqui de uma dimensão política da teoria de Platão: os fortes e os poderosos que se acham mais sábios, mais belos ou mais ricos do que na verdade são não se tornam objeto do riso. (1999, p.42)

Logo, é possível entrever em Platão a condenação moral daquele que é o objeto do riso, e não só: aquele que ri, segundo o filósofo, experimenta um prazer que tem como causa o sentimento da inveja. O julgamento moral não se dirige apenas ao risível "em si”, mas também àquele que ri. Ainda para Verena Alberti,

Combinando as observações de A República e de Filebo, podemos concluir que o conceito negativo que Platão faz do riso e do risível é determinado, em última análise, por sua concepção da filosofia como prazer puro e única forma de apreensão da verdade, em oposição à ilusão característica das paixões. $\mathrm{O}$ riso e o risível seriam prazeres falsos, experimentados pela multidão medíocre de homens privados da razão. Entretanto, ambos devem ser condenados mais por nos afastarem da verdade do que por constituírem um comportamento medíocre. (1999, p.44-5)

Já em Aristóteles, o que nos restou de sua obra sobre o riso corresponde apenas a algumas passagens dispersas em seus textos. $\mathrm{O}$ livro II da Poética, que tratava especificamente da comédia, perdeu-se e esse fato foi inclusive tema do romance $O$ nome da rosa, de Umberto Eco. Mesmo assim, a influência desse filósofo em relação aos estudos posteriores sobre o riso foi bem significativa. De acordo com Verena Alberti,

A influência de Aristóteles talvez seja a mais marcante na história do pensamento sobre o riso, principalmente no que concerne à consagração de sua definição do cômico como uma deformidade que não implica dor nem destruição. Essa definição, que se acha na Poética, estabelece-se como característica primeira do cômico já na Antiguidade e atravessa os séculos seguintes com soberania. Outra concepção corrente que remonta a Aristóteles é sua definição do riso como especificidade humana. (1999, p.45) 
Distanciando-se das ideias de Platão no que diz respeito ao caráter nocivo do riso, Aristóteles associa o acontecimento do riso ao agradável, ou seja, àquilo que produz prazer, à calma, à amizade, enfim, ao natural.

Marcus Tullius Cícero, célebre orador e político latino, também se dedicou ao assunto, provavelmente porque "teria querido legitimar o uso que ele mesmo fazia do cômico em seus discursos". (Alberti, 1999, p.57). Sua teoria acerca do riso - encontrada em De oratore, escrito em 55 a.C. - também colabora de modo assaz significativo para ampliar a significação do fenômeno. $\mathrm{O}$ aspecto mais interessante comentado por Cícero é a utilização do riso com finalidade retórica.

Seguindo esse raciocínio, esse filósofo lista uma série de vantagens conquistadas pelo orador que faz uso do riso. Verena Alberti as explica:

o emprego do risível no discurso torna o ouvinte benevolente, produz uma agradável surpresa, abate e enfraquece o adversário, mostra que o orador é homem culto e urbano, mitiga a severidade e a tristeza, e dissipa acusações desagradáveis. (1999, p.58)

Esses efeitos do uso do riso aventados por Cícero são muito pertinentes. De fato, qualquer um que provoque o riso com seu discurso é agraciado com a simpatia e a admiração daqueles que o ouvem. Assim, Cícero propõe o uso do risível, mas para alcançar objetivos sérios. E salienta a necessidade de se observar o contexto, percebendo a conveniência ou não do riso, ou seja, adaptando sua utilização a determinadas situações.

Objetivando sempre enfatizar a seriedade do risível, Cícero ainda compara as atividades de um orador e de um bufão. De acordo com ele, "o bom orador tem sempre uma razão para empregar o risível, enquanto os bufões e mimos fazem troça o dia todo e sem razão" (apud Alberti, 1999, p.59). Não há dúvida, portanto, de que Cícero enfatiza o emprego do riso visando à satisfação do orador em relação a seu discurso. O riso acrescentaria, pois, aos discursos 
um tom amigável e descontraído, que estreitaria os laços entre o orador e seu público, tornando-se mecanismos significativos para se atingir o convencimento e a persuasão.

A teoria de Quintiliano, embora bastante próxima à teoria de Cícero, merece ser mencionada, uma vez que acrescenta novidades, ampliando o conceito do riso. A obra de Quintiliano que aborda a questão é Institutio oratória, escrita em 92 e 94 d.C. Nela, é possível perceber o parentesco com a teoria de Cícero no que se refere à finalidade retórica do riso. Quintiliano, no entanto, vai além: para ele, o riso pode ser consequência de uma ingenuidade fingida e, também nesse aspecto, o riso seria um procedimento calculado com vista a se atingir um fim determinado. Verena Alberti explica a teoria de Quintiliano:

O mesmo ocorre quando se tem o ar de não compreender o que se compreende muito bem. Segundo Quintiliano, a ingenuidade fingida torna-se claramente um caso de risível localizado "em nós" - ou seja, nas pessoas prudentes que deixam escapar o dito espirituoso deliberadamente. Isso explica a observação de Quintiliano sobre as asneiras: elas são asneiras quando as deixamos escapar por imprudência, mas são elegantes se são um fingimento. (1999, p.64)

A questão do fingimento associado ao riso remete-nos certamente à própria ironia, que também irrompe, muitas vezes, de uma ingenuidade fingida.

As concepções de Cícero e de Quintiliano possuem muitos pontos de intersecção, o que inclusive é perceptível em suas designações do bufão que Quintiliano considera ser aquele que - ao contrário de um orador - deixa escapar asneiras sem aperceber-se disso.

Não podemos deixar de mencionar Demócrito de Abdera, o "filósofo que ri", de quem é contada uma história bastante interessante na segunda metade do século I a.C. em um texto intitulado Carta de Hipócrates a Damagetus: 
A história revela uma curiosa relação entre o riso, a sabedoria e a loucura. Conta a Carta que Hipócrates teria sido chamado pelos cidadãos de Abdera [situada na Trácia], cidade natal de Demócrito, porque o filósofo estaria gravemente enfermo, acometido de loucura - ria de qualquer coisa. Ao ouvi-lo e vê-lo, contudo, Hipócrates teria se convencido do contrário: Demócrito estaria mais sábio do que nunca. [...] Ao ser levado pelos abderianos ao local de moradia de Demócrito, Hipócrates avista, do alto de uma colina, o filósofo sentado sob uma árvore baixa e encorpada, grosseiramente vestido, cercado de cadáveres de animais, ora escrevendo compulsivamente, ora parando para pensar, levantando-se em seguida para examinar as vísceras dos animais. Dois dos cidadãos de Abdera que acompanham ansiosamente o médico começam a chorar para testar o filósofo. Um deles chora como uma mulher cujo filho houvesse morrido; outro, imitando um viajante que teria perdido a bagagem. Segue-se a isso a prova da loucura do filósofo: ao ouvi-los, Demócrito põe-se a rir copiosamente. Hipócrates resolve então descer a colina para ver e ouvir pessoalmente os propósitos do filósofo, deixando os cidadãos de Abdera à espera. Demócrito mostra-se extremamente cortês e satisfeito ao conhecer a identidade do visitante e, perguntando sobre o que escrevia, revela tratar-se de um livro sobre a loucura: sobre o que é, sobre como se engendra no homem e sobre como dele pode ser retirada. Por isso dissecara os animais à sua volta: para descobrir, neles, a natureza e a sede da bílis negra. ${ }^{1}$ (Alberti, 1999, p.74)

Resumindo um pouco mais a história, Hipócrates, o médico, fica impressionado com a agudeza de raciocínio de Demócrito, valorizando a oportunidade de estar ali, ao lado daquele homem considerado por todos um insano. E, conversando com Demócrito, Hipócrates lamenta que ele próprio não possa estar envolvido em tal pesquisa, uma vez que se ocupa de questões relacionadas à sua profissão: problemas domésticos, crianças, doenças, mortes...

Tal comentário de Hipócrates provoca em Demócrito um riso

1 Aristóteles, em sua obra $O$ homem de gênio e a melancolia - O problema XXX, fornece uma explicação minuciosa sobre a bílis negra. O filósofo a define como o humor da melancolia. 
extremamente forte e os abderianos, que observavam de longe, ficam ainda mais receosos. Então, Hipócrates, intrigado, quer saber a razão pela qual Demócrito ri quando deveria apiedar-se, já que o médico havia mencionado doenças e mortes. O filósofo responde:

Eu rio do homem cheio de loucura e vazio de toda ação direita, que $[\ldots]$ se comporta puerilmente, [...] que vai até o fim do mundo procurando ouro e prata, trabalhando sempre para adquirir mais bens $[\ldots]$ Eu rio também do homem que cava as entranhas e veias da terra, para as minas, enquanto se podia contentar com aquilo que a terra, mãe de todos, produz suficientemente para o sustento dos homens. Há os que querem ser grandes senhores e comandar muitos; há os que não conseguem comandar a si mesmos. Eles se casam com mulheres que logo repudiam. Eles amam, depois odeiam. Eles são muito desejosos de ter filhos, e quando eles estão grandes, os mandam para longe [...] Vivendo em excessos, eles não têm nenhuma preocupação com a indigência de seus amigos e de sua pátria. Eles perseguem coisas indignas [...]. Além disso, têm apetite por coisas penosas, porque aquele que mora em terra firme quereria estar no mar, e aquele que nele está quereria estar em terra firme. (Apud Alberti, 1999, p.75-6)

Hipócrates, incomodado, tenta refutar as ideias de Demócrito, argumentando que as ocupações da vida geram essas necessidades, que o homem não foi feito para ser ocioso e que muitos deles são bons e sérios. Hipócrates afirma, ainda, que muitos homens são bem-intencionados e que não poderiam prever o futuro de desgraças ou infelicidade. Seguindo esse raciocínio, o médico indaga finalmente: "Como, pois, você pode rir do que seja bem-intencionado?” (apud Alberti, 1999, p.76). Mais uma vez, Demócrito responde, revelando a essência de seu saber:

Se os homens fizessem as coisas prudentemente, $[\ldots]$ me poupariam o riso. Mas, ao contrário, eles, como se as coisas fossem firmes e estáveis nesse mundo, vangloriam-se loucamente, sem poder reter sua impetuosidade, por faltar-lhes a boa razão, o discernimento, o julgamento. Porque esse único aviso lhes bastaria: de que todas as coisas 
têm seu turno, o qual advém por mudanças súbitas [...]. Eles, como se a coisa fosse firme e perdurável e esquecendo os acidentes que ocorrem ordinariamente, se envolvem com várias calamidades. Se cada um pensasse fazer todas as coisas de acordo com seu poder, certamente se sustentaria em uma vida certa e tranquila, conhecer-se-ia a si mesmo, [...] contentando-se com as riquezas da natureza. [...] Eis o que me dá matéria de riso. Ó homens insensatos, vocês são bem punidos de sua loucura, avarice, insaciabilidade, [...] e de fazerem do vício virtude. (Apud Alberti, 1999, p.76)

Após o discurso de Demócrito, Hipócrates se convence de que o filósofo não era apenas muito sábio, mas o mais sábio de todos, "o único que pode tornar sábios todos os homens do mundo" (apud Alberti, 1999, p.75).

Logo, em Demócrito, o riso é fruto da insensatez humana. O filósofo, como pudemos observar, ri do homem, que se julga mais sábio do que, de fato, é. Nesse sentido, seu riso se aproxima do que Platão já expressou no Filebo: "conhece-te a ti mesmo", prescreve o oráculo de Delfos. É preciso observar, ainda, que, se em Demócrito o riso é consequência dos "defeitos" e "vícios" humanos, esse filósofo (Demócrito) se aproxima também da caracterização do cômico para Aristóteles. Na opinião de Georges Minois,

O riso de Demócrito aplica-se, portanto, à vaidade das ocupações e inquietudes humanas. Mas ele vai mais longe. Esse riso também é uma crítica radical do conhecimento, a expressão de um ceticismo absoluto. [...] Demócrito, o homem que ri de tudo, é a encarnação extrema de um ceticismo niilista que se encontra, em germe, nos pensadores céti$\cos [\ldots] .(2003$, p.61-2)

Dessa forma, Minois entende que, em Demócrito, o riso é fruto de uma constatação: a incapacidade extrema do homem de se conhecer e de conhecer o mundo. Desse modo, trata-se de um riso radicalmente cético; afinal, tal percepção a respeito do homem apenas pode nos conduzir à ideia de que nada deve ser levado a sério, uma vez que, sem o autoconhecimento e o conhecimento do mun- 
do, o ser humano - mergulhado em profunda cegueira - está imerso na ilusão, aparência e vaidade. É exatamente disso que Demócrito ri. Pigeaud observa:

O riso de Demócrito pode significar um solipsismo patológico, porque é um riso de desinteresse pelas coisas da vida, mas também o recolhimento filosófico, requisito para a sabedoria mais profunda. (Apud Alberti, 1999, p.77)

Legitima-se, portanto, a ambiguidade relacionada à questão do riso em Demócrito: seria ele fruto da loucura ou da sabedoria daquele que ri de todas as coisas? Verena Alberti comenta:

Como louco, ele não tem a medida do bem e do mal; como sábio, está acima do bem e do mal e conclama os homens à sensatez, ao mesmo tempo em que receita o riso como remédio para todos os males, inclusive o da loucura. (1999, p.77)

Nota-se que existem interpretações diferentes relacionadas à questão do riso em Demócrito: de um lado, ele pode estar imbuído de uma visão cética e niilista em relação ao ser humano, de outro, seu riso pode ser entendido como um instrumento para "conclama[r] os homens à sensatez", como na citação anterior.

Se passarmos agora para a Idade Média, vemos que o riso foi, em geral, veementemente condenado, a começar pelo "fato" de que Jesus nunca teria rido (Minois, 2003, p.120-1). Esse mito é responsável por uma consequência drástica na vida dos cristãos: como é dito que Jesus jamais riu, os cristãos, devendo imitá-lo, também não deveriam rir.

Georges Minois comenta que o riso aparece, na história cristã, quando o pecado original é cometido e, consequentemente, tudo se desequilibra:

O riso é ligado à imperfeição, à corrupção, ao fato de que as criaturas sejam decaídas, que não coincidam com o seu modelo, com sua es- 
sência ideal. É esse hiato entre a existência e a essência que provoca o riso, essa defasagem permanente entre o que somos e o que deveríamos ser. O riso brota quando vemos esse buraco intransponível, aberto sobre o nada e quando tomamos consciência dele. É a desforra do diabo, que revela ao homem que ele não é nada, que não deve seu ser a si mesmo, que é dependente e que não pode nada, que é grotesco em um universo grotesco. (2003, p.112, grifos nossos)

Assim, o riso é, também aqui, fruto de uma oposição profunda: entre o que de fato somos e o que almejamos ser. Essa verificação levaria ao riso - um riso trágico, ao que parece.

Ainda para Minois, "ninguém contribuiu mais para demonizar o riso que os pais da Igreja" (2003, p.126). Desse modo, nomes de pessoas insignes, conhecidos de muitos graças à sua devoção ao cristianismo, colaboraram com o processo de desautorização do riso. Assim, Basílio de Cesareia (apud Minois, 1999, p.126) escreve que "não é permitido rir, em qualquer circunstância, por causa da multidão que ofende a Deus, desprezando sua lei. O Senhor condenou aqueles que riem nesta vida".

De modo análogo, n'Os três livros contra os acadêmicos, santo Agostinho (apud Minois, 1999, p.127) considera que o riso é sempre desprezível, ainda que seja uma faculdade humana:

Há certos atos que parecem estranhos aos animais, mas que não são o que há de mais elevado no homem, como a brincadeira e o riso; e qualquer um que julgue a natureza humana estima que, se esses atos são do homem, são o que há de mais ínfimo nele.

É legítimo afirmar, portanto, que o riso está sob grande vigilância na Idade Média, período caracterizado pelo absolutismo da Igreja Católica. Uma vez que carrega em sua essência um caráter questionador, é banido com veemência.

Saltando para o final do século XVI, encontramos Laurent Joubert e o seu Tratado do riso, obra publicada em Paris em 1579. Um pouco depois, a partir do século XVII, já é possível perceber uma 
propensão a desarmar o riso ou exilá-lo para longe dos assuntos centrais ou "sérios" da sociedade. Mas tal atitude não é nova: basta lembrarmos as teorias de Platão e de Aristóteles. Em Aristóteles, inclusive, a comédia é relegada a um espaço marginal em relação à tragédia. E, na Idade Média, como foi comentado, os bufões e todos aqueles que riam não eram bem-vistos e deviam, pois, ser evitados, uma vez que não procuravam imitar Jesus Cristo... Verena Alberti comenta:

Na Renascença, [...] o riso teria um profundo valor de concepção do mundo, enquanto, na idade clássica, teria sido domesticado, limitando-se aos vícios dos indivíduos e da sociedade. [...] Já no século XVII, o que era essencial ou importante não podia mais ser cômico: o riso tornara-se um divertimento leve, ou ainda uma espécie de castigo útil. (1999, p.82, grifos nossos)

Assim, no século XVII, percebe-se uma tendência a associar o riso ao não sério, às tolices. $\mathrm{O}$ risível - considerado dessa maneira - foi desnudado de sua função de "revelar uma verdade oculta", encontrada apenas além dos limites do sério, do convencional. Muito distante disso, o riso estaria fadado a "tratar" apenas das situações medíocres. Para Joubert, "a coisa risível é vã, leve, frívola e sem qualquer importância [...]" (apud Alberti, 1999, p.87).

Embora pareça exatamente o oposto, é interessante observar que o Tratado de Joubert está longe de qualquer condenação ética do riso. Ainda que o objeto do riso para o século XVII e para esse filósofo sejam as coisas torpes e indecentes, a paixão que ele suscita não está associada à inveja, como vislumbramos em Platão. Ao contrário, na opinião de Joubert, "ele [o riso] é uma das mais admiráveis ações do homem, ainda mais por ser próprio ao mais admirável dos animais" (apud Alberti, 1999, p.85).

Devemos ressaltar, aqui, que Joubert atribui ao riso um caráter positivo, e esse seu ponto de vista talvez seja um dos traços mais importantes de seu Tratado. De acordo com Verena Alberti, 
entre os feitos risíveis, há aqueles que fazemos de propósito, como rasgar a roupa de alguém ou jogar-lhe água, atitudes que não são condenadas, pois o riso de Joubert caracteriza-se pela ausência de remorso: podemos rir e podemos produzir feitos risíveis propositadamente. Contudo, é preciso que não haja dano ou mal que importe muito e que a piedade não se misture à coisa risível. O riso de Joubert não é eticamente condenado porque não ultrapassa esse limite. (1999, p.115, grifos nossos)

Nesse sentido, Joubert permite que se ria da deformidade, do comportamento do outro, de sua tolice e ingenuidade, sem a presença sufocante da condenação ética do riso. Assim, em razão de estar sempre associado às atitudes frívolas e sem importância, não há prejuízos para o objeto do riso. Sem graves danos, também ficam de fora os sentimentos de piedade ou remorso.

O Tratado de Joubert sugere, ainda, uma atividade cognitiva associada ao riso. Joubert argumenta que o motivo de os recém-nascidos e os animais não rirem é porque lhes falta o pensamento ou a cogitação. Desse modo, conforme explica, "é preciso mais do que a faculdade vegetativa para ser comovido pela coisa risível: é preciso conhecer ou conceber a matéria que entra na alma" (apud Alberti, 1999, p.104).

De acordo com Verena Alberti, é importante perceber que as ideias acerca do riso não se desenvolveram de modo cronológico, obedecendo a uma sequência linear, pois "o riso não constituía objeto de inquisição bem ordenada; o que havia era um pensamento disperso, que se expressava através de polêmicas e debates" (Alberti, 1999, p.119).

Isso levou o estudioso a afunilar sua análise do fenômeno do riso em duas correntes básicas, muito recorrentes nos séculos XVII e XVIII. A primeira delas, baseada sobretudo no Tratado de Joubert, é a que acredita que o objeto do riso se opõe ao normativo e à verdade. É o que se chama de "riso clássico", e teria como cerne a crítica dos vícios e das deformidades. A segunda linha de estudos entende o riso ou como manifestação de superioridade, ou como contraste ou incongruência. 
Verena Alberti chama a atenção para as relações entre a teoria da superioridade e a ideia do riso malevolente, bem como entre a teoria do contraste e a ideia do riso benevolente. Conforme sua explanação, a partir do século XVIII, a concepção de riso benevolente começa a se destacar em relação à ideia de que o riso estaria associado sempre à deformidade e ao desvio.

O representante da teoria da superioridade do riso e a ideia do riso malevolente é Thomas Hobbes. Segundo ele, o riso está sempre associado ao orgulho que experimentamos no momento em que nos percebemos mais capazes do que alguém e, portanto, superiores. Desse modo, na opinião de Hobbes,

O entusiasmo súbito é a paixão que provoca aqueles trejeitos a que se chama riso. Este é provocado ou por um ato repentino de nós mesmos que nos diverte, ou pela visão de alguma coisa deformada em outra pessoa, devido à comparação com a qual subitamente nos aplaudimos a nós mesmos. Isto acontece mais com aqueles que têm consciência de menor capacidade em si mesmos, e são obrigados a reparar nas imperfeições dos outros para poderem continuar sendo a favor de si próprios. Portanto, um excesso de riso perante os defeitos dos outros é sinal de pusilanimidade. Porque o que é próprio dos grandes espíritos é ajudar os outros a evitar o escárnio, e comparar-se apenas com os mais capazes. (1979, p.36)

Como se pode perceber, há, nas palavras de Hobbes, a condenação ética do riso. O riso figura aqui como manifestação grosseira da superioridade de quem ri, tornando-se, por conseguinte, um instrumento de poder. Assim, na opinião de Thomas Hobbes - que nasceu seis anos após a morte de Laurent Joubert, em 1588 -, o riso constrange, uma vez que estabelece, sempre, a supremacia de um - aquele que ri - em relação à deformidade de outro - o objeto do riso. Segundo Verena Alberti,

Como em Joubert, o riso de Hobbes também é um riso das coisas torpes, indecentes e frívolas necessariamente novas e inesperadas. Mas, à diferença de Joubert, esse riso não é legitimado pela ausência de remorso, porque seu objeto não é limitado pela ausência de piedade; o riso 
sempre será acompanhado de ofensa e de vanglória. Além disso, o estado de alma em que nos colocam as coisas risíveis é um falso prazer: uma falsa superioridade, uma falsa honra, uma falsa concepção de poder futuro. (1999, p.132, grifos nossos)

Como se nota, embora quase contemporâneos, Hobbes e Joubert pensaram sobre o riso de modos diferentes. Se a teoria de Joubert autoriza o riso e o prescreve como uma espécie de "colaborador" da saúde, a de Hobbes confina o riso a uma determinada classe de homens: os desprovidos de elevação e nobreza. Na opinião de Minois, "o riso é, portanto, relegado à oposição. Reduzido à função crítica, de escárnio, de derrisão, de zombaria, ele se torna ácido" (2003, p.363).

No início do século XVIII, não se pode perder de vista a célebre figura de Anthony Ashley Cooper, conde de Shaftesbury. O objetivo principal a que ele se dedica é integrar riso e religião. Conforme comenta Minois, "Shaftesbury acredita que o bom humor está na raiz da fé, e esta, se for autêntica, deve manifestar-se no riso" (2003, p.448).

$\mathrm{Na}$ verdade, Shaftesbury conhecia a dificuldade de realização de sua proposta; afinal, já se tinha propagado nesse momento, como vimos anteriormente, a ideia de um riso agressivo e orgulhoso, defendida por Hobbes. Ciente disso, o conde reconhece, então, duas espécies de riso: a jocositas, que seria justamente o escárnio agressivo, descontrolado, marca de superioridade, e a hilaritas, tipo de riso moderado, que se deixa controlar.

A ideia de Shaftesbury era ver transformado esse riso vulgar, exorbitante e assustador num riso que se caracterizasse pelo equilíbrio e pela razão. A insegurança dos religiosos e tradicionais em relação à análise de Shaftesbury baseava-se, no entanto, no fato de esses dois tipos de riso fazerem parte da natureza humana. Ou seja, "liberar" a manifestação do riso "bom" não seria permitir que o "outro" se extravasasse? Minois, em sua obra História do riso e do escárnio, reproduz esse receio, citando alguns desses pensamentos conservadores: 
o riso vai erodir a autoridade civil e religiosa, dissolver as tradições, os ritos e as instituições, colocar em perigo todo o corpo social. [...] Traumatizados pelas zombarias de Tindal, Collins ou Toland, os membros do clérigo anglicano têm medo de rir [...]. (2003, p.450)

Shaftesbury, todavia, insiste em seu projeto e amplia o debate. Para ele, a ausência do riso na religião é a causa principal da produção de entusiastas fanáticos. Logo, o conde defende a junção das duas formas de manifestação do riso: o humor e o espírito (wit). O humor, mais sentimental, nos faria perceber que qualquer forma de coincidência perfeita do ser consigo mesmo e, depois, com o outro nada mais é do que estupidez e fanatismo. O wit, mais intelectual, seria a expressão do desenvolvimento de um espírito crítico; para Shaftesbury, "é necessária a reflexão do riso diante do espetáculo do fanatismo” (apud Minois, 2003, p.451).

Nas reflexões do conde de Shaftesbury, o riso é visto, pois, como uma "arma de combate" às verdades preestabelecidas. O riso é um instrumento sério de questionamento e deve ser utilizado de modo racional e equilibrado. Esse filósofo defende a liberdade de exposição de nossas críticas como caminho para o progresso. Segundo Verena Alberti (1999, p.135),

O modelo de liberdade em que se baseia Shaftesbury é sem dúvida o da Antiguidade, onde vai procurar argumentos para corroborar a defesa da liberdade de um ridículo à inglesa, um ridículo fino e livre, em oposição à bufonaria determinada pela tirania.

Assim, a teoria de Shaftesbury sobre o riso é, de certo modo, um manifesto em favor da liberdade. E trata-se de uma liberdade específica: a de usar o "ridículo" livremente, como uma maneira de desmascarar imposturas e superstições. Ouçamos o próprio conde sobre a capacidade de emitir juízos, que nos é inerente:

é impossível ao coração manter-se neutro e não participar constantemente, de um modo ou de outro. Por mais falsidade ou corrupção que al- 
bergue em seu íntimo, ele descobre a diferença que, no tocante à beleza eà elegância, existe entre um coração e outro, um gesto de afeição, um comportamento, um sentimento e um outro; e assim, em todos os casos em que o interesse próprio não esteja envolvido, deverá aprovar em maior ou menor grau o que é natural e honesto, e reprovar o que é desonesto e corrupto. (Butler, 1996, p.19)

No entender de Minois, Shaftesbury enuncia, em 1711, por meio de sua teoria sobre o riso, o que seria o espírito das Luzes. Para finalizar,

Shaftesbury defende a liberdade de zombar, a liberdade de questionar tudo, em uma linguagem decente, e a permissão de esclarecer e refutar qualquer argumento, sem ofender o interlocutor [...] Sem a liberdade de rir, de caçoar e fazer humor, não há progresso da razão. (Minois, 2003, p.451)

Fica aqui assinalada uma característica própria do riso: a liberdade de rir como forma de propor uma discussão sobre verdades preestabelecidas, engendrando, dessa maneira, novas possibilidades de pensamento. O riso seria, assim, um meio de propiciar a mudança e, de acordo com a situação, o progresso da razão.

No final do século XVIII encontramos ainda uma figura importante: Kant, cujo estudo acerca do riso baseia-se nas diferenças entre a razão e a sensação. O belo estaria associado à razão, ao geral e ao prazer desinteressado; para Kant, o belo apraz e sempre impõe um julgamento. Em contrapartida, a sensação estaria sempre relacionada ao agradável, ao pessoal e ao interesse, aproximando-se, pois, do prazer e da alegria. Para Kant, o que é agradável regozija. Logo,

Entre o que apraz simplesmente no ajuizamento e o que deleita (apraz na sensação) há, como o mostramos frequentemente, uma diferença essencial. $O$ último é algo que não se pode imputar a qualquer um do mesmo modo como o primeiro. O deleite (por mais que sua causa possa encontrar-se também em ideias) parece consistir sempre 
num sentimento de promoção da vida inteira do homem, por conseguinte também do bem-estar corporal, isto é, da saúde; de modo que Epicuro, que fazia todo deleite passar basicamente por sensação corporal, sob este aspecto talvez não deixasse de ter razão [...]. (Kant, 2005, p.175)

Em conformidade com a teoria do riso de Kant, o julgamento do belo prende-se à razão e, quando experimentamos qualquer sensação agradável ou desagradável, não há julgamento, mas apenas sentimento. Como conclui Verena Alberti, "nesse sentido, nem a matéria do riso nem a música têm a ver com a razão; elas só suscitam sensações agradáveis" (1999, p.163). Assim,

a música e a matéria para o riso são duas espécies de jogo com ideias estéticas ou também com representações do entendimento, pelas quais enfim nada é pensado e as quais só podem deleitar pela sua alternância, e contudo vivamente. [...] a vivificação em ambas é simplesmente corporal, embora elas sejam suscitadas por ideias do ânimo, e que o sentimento de saúde constitui por um movimento das vísceras correspondente àquele jogo o todo de uma sociedade despertada para um deleite tão fino e espirituoso. (Kant, 2005, p.177)

Seguindo esse raciocínio, o prazer do risível advém de um relaxamento súbito do entendimento, quando ele não encontra o que esperava. Nas palavras de Minois, comentando Kant, "o riso é um efeito resultante da maneira como a tensão da espera é reduzida a nada" (2003, p.420).

Em Kant, o riso é fruto de uma contradição, não obstante resulte de um excedente de entendimento. Para o filósofo alemão, o riso surge da impossibilidade de permanecer pensando:

É digno de nota que em todos esses casos o riso tem de conter sempre algo que num momento pode enganar; daí que se a aparência termina em nada, o ânimo rememora-o para tentá-lo ainda uma vez e assim, através de uma rápida sucessão de tensão e distensão, ricocheteia de um lado a outro e é posto em oscilação. [...] de modo que o pulmão expele o ar a intervalos 
rapidamente sucessivos e assim efetua um movimento favorável à saúde [...]. (Kant, 2005, p.179)

Para Kant, o prazer proporcionado pelo riso não é um prazer do julgamento, uma vez que o risível não faz parte das artes agradáveis e a sensação provocada por ele não estaria, pois, associada à razão. De forma semelhante, o prazer do risível também não pode ser um prazer do entendimento, já que o entendimento frustra-se quando não encontra o que esperava: é a expectativa reduzida a nada.

Depois de Kant, merecem destaque as ideias de Jean Paul, Baudelaire e Schopenhauer, ambientadas no século XIX. As teorias desses pensadores mostraram tamanha afinidade com os objetivos da presente pesquisa que a próxima seção será dedicada a elas. Por isso, iremos nos deslocar diretamente para o final do século XIX e começo do XX, encontrando as teorias de Bergson e Freud.

Bergson publica seus artigos sobre o riso em 1900, abordando o risível em relação à sua função na sociedade. Ele coloca sob a lupa o significado necessariamente social do riso, afastando-se, pois, de uma abordagem estética ou filosófica do risível. Desse modo,

O riso deve ser alguma coisa desse tipo, uma espécie de gesto social. Pelo medo que inspira, o riso reprime as excentricidades, mantém constantemente vigilantes e em contato recíproco certas atividades de ordem acessória que correriam o risco de isolar-se e adormecer; flexibiliza enfim tudo o que pode restar de rigidez mecânica na superfície do corpo social. (Bergson, 2001, p.15)

Por essas palavras, percebemos que o riso funciona também como uma espécie de força repressora de quaisquer comportamentos não previstos pela "ordem”. Dito de outra forma, tudo o que não é julgado normal, convencional, seria corrigido por meio do riso.

Em contrapartida, em vários momentos, Bergson fala de um mecanismo sobreposto à vida, de pessoas negando sua espontaneidade para assumir comportamentos predeterminados pelo meio social em que estão inseridas. Dessa forma, o riso pode representar 
uma reação a esse tipo de comportamento maquinal do ser humano. Vejamos:

A própria forma compassada de todo cerimonial nos sugere uma imagem desse tipo. Assim que esquecemos a seriedade do objeto de uma solenidade ou de uma cerimônia, os que tomam parte dela produzem em nós efeito de marionetes. Sua mobilidade se regra pela imobilidade de uma fórmula. É automatismo. (Bergson, 2001, p.34)

Chegamos a um impasse: ou Bergson tentou, sem muita clareza, enfatizar o caráter contraditório do riso - que atua como força que nega, ao mesmo tempo, as excentricidades e os convencionalismos - ou a sua teoria acerca do riso é contraditória. A primeira citação revela que o riso é controlador: coloca as pessoas excêntricas no seu "devido" lugar, que significa justamente o seu lugar social, agindo como outros agiriam, negando sua individualidade. Em outras palavras, ri-se do diferente a fim de que ele se torne igual e deixe de perturbar a harmonia da sociedade. Em contrapartida, na segunda passagem citada, também são objetos do riso aqueles que estão desempenhando seu papel social, uma vez que eles se tornam robóticos, maquinais e previsíveis.

Acerca desses trechos citados perguntamo-nos: qual é, enfim, o papel do riso na sociedade, para Bergson? Verena Alberti também não parece satisfeita e faz o seguinte comentário a respeito da teoria de Bergson: "seu ensaio esconde, por trás de uma aparência de coerência, a impossibilidade de se conferir um sentido ao riso" (1999, p.196).

E quanto a Freud? Podemos dizer que, em linhas gerais, Freud vê o riso causando um prazer que resulta do alívio psíquico decorrente da economia de esforço intelectual. Notamos nisso uma perspectiva que entende serem incompatíveis o riso e o pensamento sério. Minois explica o riso em Freud:

o principal obstáculo a um efeito cômico é a existência de um afeto penoso: dor ou qualquer mal, psíquico ou moral. [...] O humor impede o 
desencadeamento do afeto penoso, permite-nos economizar um desgaste afetivo, e é nisso que reside o prazer que ele propicia. [...] Nosso humor cotidiano, na maior parte das vezes, é desse tipo: ele nos economiza a cólera. (2003, p.526)

Logo, Freud analisa o riso como resultado da vitória do eu, que consegue se impor diante das vicissitudes da existência. Verena Alberti comenta que "esse riso tem razões psíquicas: é a expressão de um prazer original reencontrado, ao qual tivemos de renunciar quando a razão nos impôs o sentido" (1999, p.19). Mais uma vez, as palavras de Minois sobre o risível em Freud:

O humor é, assim, um processo de defesa que impede a eclosão do desprazer. Ao contrário do processo de recalque, ele não procura subtrair da consciência o elemento penoso, mas transforma em prazer a energia já acumulada para enfrentar a dor. (2003, p.526-7)

\section{O riso e a liberdade criadora do sujeito}

Ainda no século XVIII e caminhando para o século XIX, apesar de tantas investidas contra o riso, ele resiste, sobretudo como um meio de combate. De acordo com Verena Alberti (1999, p.159), o riso entra agora no domínio do saber, como meio de seu alargamento. Poderíamos objetar, afirmando que não há novidade alguma nisso, uma vez que o riso já havia entrado nos domínios do pensamento. Entretanto, estaríamos de certo modo enganados. Observemos a explicação de Verena Alberti:

Essa inserção do riso no terreno do entendimento não corresponde evidentemente ao desafio enfrentado por Joubert, que era pensar o riso como objeto passível de ser apreendido pelo entendimento. Agora, trata-se de pensá-lo como vinculado à atividade do entendimento. Isso fica mais claro em contraste com os ensaios de Shaftesbury, nos quais a relação entre o riso e o pensamento já sobressaía, mas para denunciar a falsidade. Entre o "ridículo" e a "verdade" havia, para Shaftesbury, 
uma relação de exclusão; agora o risível será capaz de alargar o conhecimento, como se não fosse mais incompatível com a verdade. (1999, p.159-60, grifos nossos)

Como se vê, embora o riso tenha sido associado por Joubert ao entendimento, isso ocorreu apenas no sentido de que é necessária certa atividade cognitiva para perceber a situação risível, que é sempre leve e sem importância, como vimos. Dito de outra maneira, o pensamento é ativado somente para que se localize o risível: ou seja, o ato cognitivo ocorre no sujeito para que ele diferencie o sério do não sério. Feito isso, o sujeito assimila o objeto do riso, que está nos domínios do não sério. $\mathrm{O}$ entendimento, ou ato cognitivo ou pensamento antecedem o risível, de modo que não ocorre a inserção do riso no terreno do entendimento. O riso e o entendimento são distintos e separados.

Conforme comenta Verena Alberti, havia realmente uma relação entre o riso e o pensamento em Shaftesbury. Nesse caso, porém, o riso associado ao entendimento acontece "apenas" para denunciar o erro. Ainda que essa utilização do riso seja interessante - e por isso as aspas em apenas - o caminho apontado pelos estudiosos do riso nos séculos XVIII e XIX contribuiu com maior peso para nossa pesquisa. $\mathrm{O}$ caminho por eles trilhado nos mostra que há conciliação entre o riso e a verdade e que, por conseguinte, o riso se constitui como possibilidade de ampliação do conhecimento.

Os grandes representantes dessa interpretação do fenômeno do riso são Jean Paul, Schopenhauer e Baudelaire. Johann Friedrich Richter, mais conhecido pelo pseudônimo de Jean Paul (1763-1825), não pode ser mencionado sem levarmos em consideração o contexto histórico e sobretudo literário no qual está inserido. Toda a sua obra está imbuída de humor grotesco, que a Alemanha desse período havia herdado do intenso "Sturm und Drang" (1767-1786), movimento literário que deu ensejo ao "mal do século" romântico, com significativa propensão ao humor negro. Conforme comenta Minois, 
a tensão é fonte de grotesco e de situações ridículas, até mesmo burlescas, poderíamos dizer, pela permanente defasagem entre o nobre e o trivial. [...] é o que Jean Paul chama de "humor assassino", que não se aplica a este ou àquele aspecto da realidade, mas à realidade inteira. É a ridicularização do mundo inteiro. [...] Esse riso não visa nem a denunciar nem a expiar; ele resulta do espetáculo de inanidade universal, do sublime invertido. (2003, p.530)

Trata-se de um riso que nasce da percepção de um abismo entre o sujeito e o mundo em que ele vive:

O riso romântico é o consolo do homem prisioneiro de um mundo que ele ama, apesar de tudo. O mundo é miséria, sofrimento, caos do qual não se pode escapar. Então, o riso protege contra a angústia, ao mesmo tempo que a expressa. Ele é alegria e protesto. $\mathrm{O}$ grande mistério é o da morte, que nos espreita zombando com suas órbitas vazias e um sorriso de desafio. O que fazer? Rir ou perder a face. (Minois, 2003, p.540)

Verena Alberti (1999, p.165), por sua vez, procura analisar o riso em Jean Paul de uma perspectiva mais técnica. Para ele, o ponto mais interessante dos estudos de Jean Paul - muito citados pela literatura contemporânea - é a preeminência do sujeito. Assim, segundo a teoria de Jean Paul, o cômico não se localiza no objeto, mas sim no sujeito. Nesse sentido,

a sensação suscitada pelo risível [...] só pode ser despertada se o risível for percebido enquanto representação. Um equívoco ou uma ignorância não são risíveis em si. Para que provoquem o riso, é preciso que se tornem manifestos através de uma ação; a ação e a situação devem ser "igualmente contempláveis" para que sua contradição chegue à altura do cômico. (Apud Alberti, 1999, p.167-8, grifos nossos)

Logo, o objeto nunca apresenta características próprias que o tornem cômico a priori. É somente porque temos a faculdade de ver a situação "em espetáculo" que ela passa a ser cômica. Fica legiti- 
mada, pois, a primazia do sujeito, que produz o cômico no momento em que empresta seu saber a uma situação específica. Verena Alberti ainda argumenta que

O empréstimo da opinião do sujeito ao ser cômico é ainda confirmado pelo fato de nós mesmos jamais nos considerarmos cômicos no momento da ação, mas somente depois, quando um "segundo eu" julga o primeiro. (1999, p.168)

Por conseguinte, a teoria de Jean Paul vem ao encontro do pensamento que vê o riso não como algo que se opõe ao sério, mas sim como um acontecimento que pode ampliar o conhecimento e até revelar o sério ou a verdade. Além disso, o ponto essencial dessa teoria acerca do riso é a supremacia do sujeito; dele depende esse movimento de ampliação do conhecimento ou de descoberta de verdades.

É interessante perceber que a valorização do sujeito em Jean Paul está intimamente conectada a seu momento histórico. Ele viveu à época da Revolução Francesa, evento que marcou a tomada do poder pelo sujeito empreendedor. Além disso, embora o autor não tenha participado do movimento romântico alemão (integrado por figuras como Friedrich Schlegel, Novalis, Eichendorff e E. T. A. Hoffmann), foi contemporâneo dessa estética que notoriamente defende a supremacia do sujeito sobre a obra. É digno de nota que Friedrich Schlegel tenha sido o grande teórico da chamada ironia romântica, categoria de interesse para o presente livro. $\mathrm{E}$ a ironia romântica caracteriza-se justamente por ser um meio de o sujeito criador refletir dentro da obra criada sua perspectiva crítica. Trata-se de um importante meio para esse sujeito explicar e comentar aspectos diversos, realizar reflexões sobre o próprio ato criativo, enfim, marcar sua presença.

A teoria de Jean Paul acerca do riso enfatiza o movimento livre do entendimento, sem o qual não há qualquer possibilidade de criação. Vejamos suas palavras: 
Quando o espírito se faz inteiramente livre [...] - quando há, com efeito, um caos, mas acima dele um espírito santo (heliger Geist), que paira, ou, antes, um espírito capaz de infusão, o qual, entretanto, é muito bem formado e continua a se formar e a se gerar - quando, nessa dissolução geral, estrelas caem, homens ressuscitam e tudo se mistura entre si para formar algo novo - quando esse ditirambo do chiste preenche o homem mais com luz do que com formas, então lhe é aberto, através da igualdade geral e da liberdade, o caminho para as liberdades e as invenções poética e filosófica. (Jean Paul, apud Alberti, 1999, p.172.)

Compreender esse trecho é imprescindível. Dele podemos inferir que as ideias de Jean Paul sobre o riso abarcam muito mais do que o estritamente risível. Elas evocam, na verdade, uma discussão sobre a própria criação artística.

Aproximando-se das ideias de Jean Paul encontramos Charles Baudelaire. Também para esse poeta, o cômico se localiza no sujeito e não no objeto. Vejamos:

A força do riso está em quem ri e não no objeto do riso. Nada é cômico em si mesmo. É a intenção maldosa do ridente que vê o cômico; aquele que ri não é o homem que cai, a não ser que este tenha adquirido a força de se desdobrar rapidamente e assistir como espectador desinteressado aos fenômenos de seu eu. Mas isso é raro. (Baudelaire, apud Minois, 2003, p.534)

Assim, segundo Baudelaire, não existe o cômico em si mesmo. Como Jean Paul, Baudelaire acredita que deve haver um movimento do sujeito no sentido de considerar ou não um objeto, uma situação ou até uma pessoa como cômicos. Na visão de Baudelaire, não há risos desprovidos de intenção ou risos inocentes. Indagado sobre o riso das crianças - que seria aparentemente ingênuo -, Baudelaire retruca: "Para isso seria preciso provar que as crianças são seres inocentes. Olhai-as: são projetos de homens, isto é, satãs em embrião" (apud Minois, 2003, p.534). Sua afirmação é deveras engraçada, uma vez que se contrapõe à ideia que em geral fazemos sobre 
as crianças: seres angelicais e ingênuos. Essa contradição causadora do riso nos remete ao filósofo Arthur Schopenhauer.

A teoria do riso de Schopenhauer - que se relaciona intimamente com a teoria da incongruência - encontra-se em sua principal obra, O mundo como vontade e representação. Como em Jean Paul, percebemos em Schopenhauer uma reflexão filosófica e artística que vai além da questão do riso. Segundo Verena Alberti,

A explicação do riso tem um lugar preciso: rimos da incongruência entre as duas formas de representação pelas quais apreendemos o mundo, ou, mais especificamente, pelas quais o mundo é, já que ele só existe para o sujeito. (1999, p.172)

Por meio desse comentário acerca da teoria de Schopenhauer, faz-se clara uma reflexão que, como dissemos, excede os domínios do risível. Na verdade, a fim de compreender suas ideias acerca do riso, precisamos, antes, enveredar pelos caminhos da filosofia e entender o sentido das duas formas de representação pelas quais, segundo Schopenhauer, assimilamos o mundo.

O título de sua principal obra já anuncia que, de acordo com esse filósofo, "fora a vontade e a representação nada nos é conhecido, nem passível de ser pensado” (apud Alberti, 1999, p.173). Para ele, todo tipo de manifestação existente no mundo é representação realizada por um sujeito. Fica evidente o ponto de contato com Jean Paul e Baudelaire.

As duas formas de representação por meio das quais o sujeito apreende o mundo são a representação intuitiva ou concreta e a representação abstrata. Elas correspondem, respectivamente, ao entendimento e à razão. Verena Alberti explica:

Às duas classes de representação correspondem duas faculdades de conhecimento: o entendimento (Verstand), que concebe diretamente as manifestações do mundo e conhece as causas através dos efeitos, e a razão (Vernunft), que só pode saber. O que o entendimento conhece de modo concreto chama-se de realidade, isto é, a passagem correta do efeito, no 
objeto, a suas causas. O que a razão conhece de modo correto chama-se de verdade, isto é, um julgamento abstrato que tem fundamentos suficientes. Quando o entendimento se engana, tem-se a aparência (Schein), e quando a razão se engana, o erro (Irrtum). (1999, p.173)

A teoria de Schopenhauer é complexa e não nos compete entrar aqui em detalhes. No entanto, é importante notarmos que ela nos explica a existência de uma forma concreta e de uma forma abstrata de assimilarmos o mundo. Ao modo concreto ou intuitivo liga-se o entendimento, que pode conhecer as causas apenas por meio de seus efeitos; talvez seja interessante pensar nos efeitos como espécies de "concretizações" ou "acontecimentos" consequentes de causas anteriores. Assim, podemos compreender por que essa representação - a intuitiva ou concreta - só conhece os efeitos. À representação abstrata liga-se a razão, que apenas pode saber, ou seja, não há aqui "comprovações" ou "efeitos".

Schopenhauer chama de "realidade" àquilo que o entendimento conhece de modo concreto e de "verdade" o que a razão conhece de modo abstrato. Dito de outra maneira, se, como vimos, o entendimento está relacionado à representação concreta, aquilo que entendemos corresponde àquilo que vemos, que é concreto, ou seja, considerado por nós "realidade". Em contrapartida, o que a representação abstrata ou a razão conhece de modo correto chama-se "verdade", uma vez que esse é o nível dos conceitos.

Em sua teoria, Schopenhauer salienta a necessidade de correspondência entre essas duas formas de apreendermos o mundo. Verena Alberti comenta:

Enquanto o entendimento tem por função o conhecimento direto de efeito e causa, a razão tem por função a formação de conceitos. Estes últimos devem contudo ter por fundamento o conhecimento intuitivo [...]: todo pensamento abstrato que não tem uma semente concreta é pobre, e é por isso que todo conceito deve poder ser demonstrado através das formas de representação direta do mundo. (1999, p.173) 
Por aí se vê que a representação intuitiva ou concreta tem prioridade em relação ao pensamento abstrato. Segundo Schopenhauer, um conhecimento novo existe apenas se partimos do concreto, examinando diretamente as coisas, para então transpor esse conhecimento concreto em conceitos:

De imediato se mostra a incongruência do conceito com a realidade, mostra-se como o primeiro nunca desce ao particular e como sua universalidade e rígida determinidade não combinam com as finas nuances e modificações variadas da efetividade. O pedante, por conseguinte, com suas máximas universais, quase sempre é apanhado de surpresa na vida, mostra-se imprudente, destituído de gosto, incompetente; na arte, para a qual o conceito é infrutífero, produz abortos maneiristas, rígidos e sem vida. (2005, p.111)

A razão é, muitas vezes, incapaz de apreender todas as minúcias que a representação intuitiva percebe. Assim, segundo Schopenhauer, a razão, isolada, não aumenta o conhecimento: "ela lhe confere uma nova forma, porque transforma em conceito abstrato o que já era conhecido intuitivamente" (apud Alberti, 1999, p.173). Todavia, Verena Alberti salienta ainda um outro aspecto da teoria de Schopenhauer:

Necessita-se, porém, da representação abstrata para fixar resultados e difundi-los. É possível, por exemplo, construir uma máquina com um conhecimento unicamente intuitivo se o inventor a faz sozinho, mas se várias pessoas a constroem em momentos diferentes, é necessário desenvolver um plano de construção in abstracto, para o qual deve-se recorrer à razão. (1999, p.173)

Mesmo assim, Schopenhauer explica (conforme lemos em Alberti, 1999, p.173) que há casos em que o conhecimento intuitivo deve realmente coordenar as ações, como em alguns jogos, para afinar instrumentos musicais ou, ainda, para cantar.

A partir dessa rápida exposição das duas formas de representação pelas quais assimilamos o mundo de acordo com a visão de 
Schopenhauer, temos as bases para acompanhar o pensamento desse filósofo sobre o fenômeno do riso. Conforme explica Schopenhauer, o risível é fruto da incongruência entre os conhecimentos abstrato e intuitivo:

Ora, é exatamente a incongruência entre o conhecimento intuitivo e o abstrato, em virtude da qual este está para aquele como um trabalho de mosaico está para a pintura, o fundamento de um fenômeno notável que, tanto quanto a razão, é exclusividade da natureza humana, não tendo recebido até agora, apesar de renovadas tentativas, nenhuma explicação aceitável. Trata-se do riso. [...] De fato, o riso se origina sempre e sem exceção da incongruência subitamente percebida entre um conceito e os objetos reais que foram por ele pensados em algum tipo de relação, sendo o riso ele mesmo exatamente a expressão de semelhante incongruência. (Schopenhauer, 2005, p.109, grifos nossos)

Desse trecho é possível inferir que, segundo o filósofo em questão, o riso acontece quando há a submissão paradoxal e inesperada de um objeto a um conceito que não lhe diz respeito. Conforme explica Verena Alberti, "o objeto se deixa pensar pelo conceito, mas não tem nada a ver com ele e se diferencia claramente de tudo o que pode ser pensado pelo conceito" (1999, p.174). Dessa forma, para Schopenhauer,

Quanto mais correta, de um lado, é a subsunção de tais realidades ao conceito e, de outro, quanto maior e mais flagrante é a sua inadequação com ele, tanto mais vigoroso é o efeito do risível que se origina dessa oposição. Todo riso, portanto, nasce na ocasião de uma subsunção paradoxal e, por conseguinte, inesperada: sendo indiferente se é expressa por palavras ou atos. Essa é, resumidamente, a explanação correta do risível. (2005, p.109)

Schopenhauer ainda comenta o estado prazeroso provocado pelo riso:

A percepção da incongruência do pensado (Gedachten) com o contemplado (Wirklichkeit), nos dá portanto alegria, e nós nos entregamos 
de bom grado à comoção convulsiva suscitada por essa percepção. [...] A causa desse prazer é a vitória da representação intuitiva sobre a abstrata, do entendimento sobre a razão: percebemos que a razão, com seus conceitos abstratos, não é capaz de descer à infinita diversidade e às nuanças do concreto, isto é, da forma de conhecimento primeira. (Apud Alberti, 1999, p.175)

Schopenhauer explica, portanto, que o riso - próprio do homem, que é um ser racional - acontece no momento em que se conclui que o pensamento abstrato não pode ir além dele mesmo: "rimos porque a incongruência entre o pensado e a realidade nos mostra as limitações do pensamento" (Alberti, 1999, p.176).

Finalmente, ainda é digno de nota o fato de sua teoria também apresentar uma definição do contrário do riso. Seguindo o raciocínio desenvolvido por Schopenhauer, se o risível origina-se de uma ausência de conformidade entre o pensamento e a realidade, o sério é consequência da harmonia entre o conceito e a concretização ou realidade. Assim, "o sério está convencido de que pensa as coisas como elas são e de que elas são como ele as pensa" (Alberti, 1999, p.176).

Todavia, para o filósofo alemão, não existe concordância plena entre as duas formas de representação, ou seja, entre o concreto ou intuitivo e o abstrato. Minois ainda acrescenta que, para Schopenhaver,

só as pessoas sérias sabem rir: quanto mais um homem for capaz de uma inteira gravidade, mais franco será seu riso. [...] Para rir bem, é preciso ser um homem de convicção, acreditar firmemente em alguma coisa e constatar, de repente, que se estava enganado. (Minois, 2003, p.516, grifos nossos)

Como se vê, Schopenhauer de fato não acredita na identidade perfeita entre pensamento e realidade:

Quanto mais a congruência parece perfeita, mais facilmente pode ser revogada por uma incongruência inesperada, e é por isso que a pas- 
sagem do sério ao riso é tão fácil. Ou seja, no limite, o sério é, para Schopenhauer, a aparência de uma congruência que não existe. A passagem fácil do sério para o riso pelo advento de uma incongruência inesperada revela o caráter virtualmente enganador de todo acordo entre a realidade e o pensado. (Alberti, 1999, p.176, grifos nossos)

Legitima-se, portanto, a profundidade e relevância dos estudos realizados por Schopenhauer acerca do riso. Sua teoria vai muito além do risível, convidando-nos a refletir filosoficamente sobre o conhecimento, sobre o conceito de realidade e, enfim, sobre nossa própria condição de "estar no mundo".

\section{Um sorriso irônico para a razão humana superada}

Esperamos que tenha ficado claro nosso interesse pela ideia do risível como fruto de uma incongruência, pois esse riso, além de propiciar o estudo de relações fundamentais com a ironia e a paródia, é um riso que, unido a essas modalidades, convida o sujeito a refletir filosoficamente. Vimos que as ideias mais importantes acerca desse "riso sério" nos chegam a partir de Schopenhauer, que enfatiza o riso como fruto de uma contradição, de Jean Paul, que defende a teoria do riso como "construção" de um "sujeito criador", e, ainda, de Baudelaire, que faz um acréscimo importante ao salientar a intenção inerente ao acontecimento do riso. As palavras de Verena Alberti vêm ao encontro de nosso pensamento:

o riso seria simultaneamente um conceito histórico - um objeto a ser apreendido pelo pensamento - e um conceito filosófico - um conceito em relação ao qual o próprio pensamento é pensado. Podemos acrescentar as teorias de Jean Paul e de Schopenhauer a esse conjunto, porque, para eles, a significação do riso (o resultado de sua apreensão enquanto objeto do pensamento) é dada pelo fato de ele se situar em um espaço além do pensamento sério, necessário ao próprio pensamento. Essa simultaneidade marca o pensamento moderno sobre o riso, já que, até esse momento, apreender o significado do riso não era 
declarar sua relação com um fundamental não-sério; até esse momento, o não-sério não era fundamental. (1999, p.199)

É preciso perceber que, nesse trecho, Verena Alberti se refere ao "sério" como um conceito preestabelecido pela ordem. É nesse sentido que devemos entender o riso desses filósofos, como um movimento que nos mostra um espaço além dos limites da convenção ou um espaço que transcende o "sério" e que, portanto, é necessário conhecer. O riso proposto por Schopenhauer, Jean Paul e Baudelaire é um riso sério, desta vez sem aspas, pois corresponde, de fato, a um caminho para o "novo", para o impensado.

Nesse sentido, queremos nos debruçar agora sobre a maneira como esse riso acontece na prática. Para Umberto Eco, "temos aquilo que Pirandello chama de cômico quando nasce a 'percepção do contrário”" (2006, p.72). Debruçando-se sobre o cômico em Pirandello, Eco toma-lhe emprestado um exemplo para elucidar a ideia de contraste:

Pirandello dá o exemplo de uma velha, já decadente, que se cobre de cosméticos, se veste como uma mocinha e tinge os cabelos. Ele diz: "Intuo que aquela velha senhora é o contrário daquilo que uma velha senhora respeitável deveria ser." Eis o incidente, a ruptura das expectativas normais, o senso de superioridade com o qual eu (que compreendo o erro do outro) rio. (2006, p.73)

Se, deparados com essa cena, ríssemos, certamente nosso riso seria a consequência da percepção de um disparate, de uma contradição: teríamos nos dado conta da oposição, da distância mesmo entre a juventude e a velhice. Vale dizer que a expressão da dúvida em "se ... ríssemos" deve sempre ser mantida, pois, como vimos, o cômico está no sujeito; não existe nada risível em si mesmo: existem, sim, situações "aguardando" a ação cognitiva de um sujeito.

Conforme vimos em Schopenhauer, é exatamente a falta de congruência entre nossa razão e a realidade a causadora do efeito risível. Assim, o riso irrompe no momento em que nos certificamos 
do abismo existente entre aquilo que pensamos ou nossos conceitos e os fatos concretos, tal como se afiguram na realidade.

O exemplo de Pirandello, citado por Umberto Eco, certamente contempla a teoria do riso em Schopenhauer. No entanto, o filósofo para quem o riso é fruto de uma incongruência ampliaria o comentário final acerca do episódio da velhinha, questionando, talvez, a questão da superioridade relacionada àquele que ri. Para Schopenhauer, o riso nasce principalmente da percepção de meu erro, de meus conceitos frente à realidade. Logo, não haveria a sensação de superioridade do sujeito que ri. Ao contrário disso, seu riso seria justamente a expressão de sua precariedade racional diante de toda a gama de variações propostas pela realidade concreta.

Como a explicação do riso deixada por Schopenhauer é bastante filosófica e abstrata, acabamos sentindo a necessidade de observá-la "funcionando" na prática. Sendo assim, descreveremos e depois comentaremos dois esquetes disponíveis na internet, que são encenados na cidade de São Paulo; caracterizam-se como exemplos extraliterários, dada a própria natureza do tipo de ironia e de riso analisados. O primeiro deles está inserido num show intitulado "Os melhores do mundo". Trata-se de um assalto que acabara de acontecer. A cena é a seguinte: dois policiais, um deles tenente, conversam com o assaltante, procurando convencê-lo a libertar os reféns.

Toda a conversação se faz muito engraçada quando, logo no início da cena, percebemos que quem está no comando da situação é o assaltante - ainda que os policiais fiquem repetindo que eles são a autoridade e que existe entre eles - policiais e assaltante - uma hierarquia. Na verdade, essa fala, tão exaustivamente repetida, já causa o riso, pois está em contraste com a situação "real", caracterizada justamente pela inflexibilidade do assaltante.

Então, como os policiais cometessem muitos erros de português - todos eles explicados com muita propriedade pelo assaltante -, este decide: para cada erro de português, um refém será assassinado. Os policiais ficam desesperados e a cena se torna muito cômica, porque, agora, eles precisam vigiar a sua fala. Um deles, considerando a gravidade da situação, decide telefonar para uma autori- 
dade-e, nesse momento, "cai por terra" o teórico poder da polícia. Sugere um telefonema para o presidente da república, e o outro conclui: “- Melhor não. Será uma chacina!”.

No final, o assaltante acaba incorrendo em um erro de português e comete o suicídio com um tiro. Um dos policiais conclui, para fechar a cena "com chave de ouro": "- Ele se autossuicidou-se a si mesmo!". O riso é geral.

O outro esquete que descreveremos é intitulado "Como educar seu filho na favela" e está inserido no show "Terça insana”. É encenado por outros atores, também excelentes "preparadores" do riso. Aqui, uma líder comunitária lança um livro cujo título é justamente Como educar seu filho na favela. Essa personagem já entra em cena explicando que, na verdade, quem escreveu o livro foi sua filha, pois ela - a líder comunitária - é semianalfabeta. Salienta, porém, que "ditou tudo direitinho".

Por meio de um vocabulário todo errado, a personagem da líder comunitária dá "dicas" sobre como educar uma criança na favela. Entre tais sugestões, temos as seguintes: esconder uma comida, botar num lugar mais alto, pois, segundo a personagem, "um pão que você esconde já é o café do dia seguinte; uma farinha que você bota a mais pra poder engrossar o feijão; um açúcar que você deixa de botar num chá [...]".

A personagem comenta, ainda, situações recorrentes que agravam ainda mais seu sofrimento; por exemplo, sua filha começou a comer pasta de dentes... Outra questão tratada, obviamente pelo viés do humor, é o "problema da paralisia"; a líder pergunta ao público: "- Qual é a dona de casa que nunca se sentiu uma aleijada no supermercado, sem poder 'pegar' aquele produto bom???”. E a cena se desenrola dessa maneira até o final.

Como se vê, nos dois esquetes descritos, encontramos uma forma interessante de construção do humor, forma esta que dialoga com as teorias propostas por Schopenhauer, Jean Paul e Baudelaire acerca do riso. No primeiro caso, o que põe em cena o encontro entre dois policiais e um assaltante, é possível encontrar uma crítica bastante séria sob a encenação jocosa dos atores. 
Para começar, já existe uma oposição entre nossos conceitos e a realidade efetiva quando percebemos que quem comanda toda a negociação é o assaltante. Ou seja, esperamos que a polícia seja sinônimo de ordem e de segurança, mas somos confrontados com o despreparo completo dos policiais diante daquela situação. Temos aqui, sem dúvida, a incongruência entre a razão e a efetividade colocando em cena o riso.

Esse contraste entre os modos abstrato e concreto de assimilarmos o mundo é cada vez mais acentuado no desenrolar da cena. As$\operatorname{sim}$, quanto mais os policiais repetem que eles dão as ordens e que, portanto, devem ser respeitados, mais são vilipendiados pelo assaltante. Os policiais cometem erros de português e são corrigidos pelo assaltante, que conhece todas as regras gramaticais. Logo, também somos surpreendidos pela figura do assaltante: nossa razão parece não conceber a imagem de um "assaltante culto", no entanto, nós nos deparamos com ela em cena. Eis outra incongruência, ou um motivo a mais para rirmos.

No segundo esquete - o da líder comunitária que lança um livro -, encontramos também uma incongruência principal promovendo o riso: a plateia consulta a sua razão e seleciona alguns assuntos passíveis de ser tratados num livre intitulado Como educar seu filho na favela; é, todavia, "traída". Ao nos depararmos com esse título, pensamos (todos, provavelmente) em questões relacionadas à educação escolar, ao desenvolvimento ético desses cidadãos, na possibilidade de envolvimento com drogas, tão frequente em todas as camadas sociais, entre outros "temas". O assunto do livro é, no entanto, especificamente, alimentação. O riso não advém unicamente dessa oposição, contudo. Essa incongruência desdobra-se em outra.

Assim, quando percebemos que o grande tema do livro é "alimentação", da mesma forma, criamos expectativas, que são, novamente, negadas. Pensamos, talvez, na qualidade dos alimentos e ficamos "chocados" no momento em que a líder comunitária começa a listar as dicas relacionadas à educação de seu filho, entre elas, esconder alimentos, colocá-los em lugares mais altos para as 
crianças não comerem tudo, etc. Aqui, sim, o riso irrompe, como resultado de um embate entre a razão e a realidade concreta.

Trata-se, mais uma vez, do risível como produto da incongruência entre nossos conceitos e aquilo que Schopenhauer designou "modo concreto ou intuitivo" de apreensão do mundo. Não podemos esquecer, ainda, que esse riso é também fruto da percepção de um sujeito e que, como um riso sério, tem um propósito. Há alguns aspectos interessantes que merecem comentário. Se analisado superficialmente, o esquete "Como educar seu filho na favela" aparenta insensibilidade e indiferença em relação aos problemas enfrentados pelos menos favorecidos socialmente.

De fato, é curioso observar a reação das pessoas diante dessa peça. Há sempre um grupo que não vê razão alguma para rir, associando o esquete a uma espécie de "humor negro". Na verdade, para alguns estudiosos, não há nada que atrapalhe mais o acontecimento do risível do que o sentimentalismo. Henri Bergson nos socorre nesse momento. Segundo ele, "o riso não tem maior inimigo que a emoção” (2001, p.3). E continua:

Numa sociedade de puras inteligências não mais se choraria, mas talvez ainda se risse; ao passo que almas invariavelmente sensíveis, harmonizadas em uníssono com a vida, nas quais qualquer acontecimento se prolongasse em ressonância sentimental, não conheceriam nem compreenderiam o riso. (2001, p.3)

Trata-se de uma discussão extremamente interessante sob vários aspectos. Em primeiro lugar, Bergson sugere uma curiosa associação entre riso e inteligência ou, usando um vocábulo de conotação mais neutra, entre riso e razão e entre choro, lágrimas e emoção. De fato, homens menos sensíveis e mais racionais tendem a rir mais das situações, ainda que sejam marcadas por certa tragédia.

Desse modo, o riso só acontece se, diante de tal espetáculo, pudermos nos livrar momentaneamente da emoção a fim de enxergarmos "com olhos mais livres". Assim, perceberemos que sob a "piada" existe uma intenção séria, uma preocupação em denunciar 
a situação drástica vivida por inúmeras famílias brasileiras. Na verdade, talvez estejamos expressando a ideia errada de que o riso se contraponha ao sério, como fizeram alguns estudiosos já comentados anteriormente.

Buscando uma forma mais adequada de expressão, a "intenção séria" que acabamos de mencionar não parece estar sob o risível: na realidade, o riso nos conduz a essa intenção mais grave de denúncia. Como vimos, é justamente a quebra de expectativa entre o que esperamos que aconteça e o que de fato se dá a causadora do riso. $\mathrm{O}$ que ocorre de especial no caso do esquete "Como educar seu filho na favela" é que aquilo que efetivamente "se dá" deve ser também interpretado pelo viés da ironia.

Dito de outra maneira, a plateia deve perceber uma primeira incongruência entre o "pensado" e o "efetivo", todavia, caso a ação cognitiva do sujeito seja interrompida nesse momento, o que teríamos seria, de fato, ou a ausência do riso nos mais emotivos, ou um riso de indiferença em relação à situação apresentada. $\mathrm{O}$ sujeito deve, pois, "superar" esse primeiro choque - o que significa deixar a emoção e o julgamento de lado - para perceber a crítica realizada entre as malhas da ironia.

Por conseguinte, temos, no plano que Schopenhauer chama de "realidade concreta", uma mãe ensinando outras a "educar" seus filhos escondendo deles os alimentos; essa declaração é risível, pois, como dissemos, quebra a nossa expectativa de que algo "sério" fosse retratado. Na verdade, trata-se, sim, de um assunto sério, contudo, colocado ou construído ironicamente. Logo, se num primeiro momento rimos das declarações "absurdas" da líder comunitária, somos convidados, posteriormente a refletir sobre o trágico de sua situação. Fica legitimada, mais uma vez, a necessidade veemente da participação do sujeito na construção do sentido de textos cuja estrutura é marcada pelo embate de vozes ou pela dissonância.

Enquanto no primeiro esquete comentado - o dos policiais - parece haver apenas uma incongruência entre o conceito que em geral se tem sobre os policiais e o que eles, realmente, são, no caso do segundo esquete, a construção do riso é mais complexa, ao que pa- 
rece. É claro que a percepção do sujeito sobre a contradição entre o que acreditamos ser a matéria do livro, no segundo esquete, e o que de fato é o assunto do livro já é suficiente para ocasionar o riso, como afirmamos anteriormente. Todavia, aquele riso mais sério, que Umberto Eco chama de "humorismo culto" (2006, p.81), este só é possível, nesse caso, por meio da revelação da ironia.

Assim, merecem comentário alguns aspectos interessantes em relação à construção do humor. O primeiro deles, já tão citado, é justamente o riso proposto por Schopenhauer, que é o riso como consequência de um contraste entre nossos conceitos e a realidade concreta. O que nos faz rir é, sem dúvida, a junção de imagens que têm ideias adicionais contrárias.

Como, após tantas considerações, podemos inferir que a incongruência apontada no parágrafo anterior é condição essencial para o acontecimento do riso, seria possível supor que, quanto maior for o senso do "belo" no sujeito, mais ele seria capaz de perceber o "ridículo”. É importante salientar, entretanto, que essa ideia não deve nos conduzir à imagem de um riso que se opõe ao "sério", ao "oficial". Na verdade, estamos mais próximos da teoria de Schopenhauer quando compreendemos que o "ridículo" ou o "absurdo" não estão na realidade concreta, mas, sim, no sujeito, que acredita que sua razão pode dar conta de prever todas as nuanças do mundo efetivo. Conforme explica Verena Alberti,

Em Schopenhauer é a razão (a gravidade, o sério) que se torna ridícula: ela tem a aparência de verdade, porque não é capaz de alcançar a realidade. Os conceitos pelos quais a razão "pensa" a realidade estão sempre sujeitos a um desnudamento que revele sua falsidade, e esse desnudamento nada mais é do que o objeto do riso. (1999, p.196, grifos nossos)

Seguindo esse raciocínio, quanto mais "pensante" e racional for o sujeito, quanto mais formador de teorias e conceitos, mais suscetível estará ao acontecimento do riso, pois maior será o choque entre a sua razão e a efetividade. $\mathrm{O}$ momento desse embate - o instante de irrupção do riso - corresponde exatamente à oportuni- 
dade de alargar a percepção do sujeito que, buscando compreender o contraste, conclui sobre a necessidade de revisão de seus conceitos puramente abstratos. Para Verena Alberti,

O estatuto do riso como redentor do pensamento não poderia ser mais evidente. $\mathrm{O}$ riso e o cômico são literalmente indispensáveis para o conhecimento do mundo e para a apreensão da realidade plena. Sua positivação é clara: o nada ao qual o riso nos dá acesso encerra uma verdade infinita e profunda, em oposição ao mundo racional e finito da ordem estabelecida. (1999, p.12)

Estamos, pois, diante do "cômico de contraste", aquele que se presta à ampliação do conhecimento, uma vez que é caracterizado pela presença da razão. O pré-requisito essencial para o acontecimento desse riso é, ao que parece, o uso da razão: apenas por meio de uma ação cognitiva o sujeito se dá conta da distância entre o que pensa e o que, de fato, é. Paradoxalmente, a mesma razão que se vê malograda em presença da realidade concreta, conclui sobre a necessidade de revisão e de alargamento dos conceitos do sujeito.

Após esse riso, nosso conhecimento é maior, pois extrapolamos o universo das ideias preconcebidas para acessar outras possibilidades de "verdade". O riso do contraste promove, portanto, o questionamento e a queda de algumas convenções, colaborando, assim, com o progresso da razão.

Outro aspecto que nos interessa muito é a relação entre a ironia e o humor. Semelhante ao que acontece no esquete "Como educar seu filho na favela", há muitos casos de construção do riso nos quais a ironia e o cômico estão tão ligados que é uma tarefa difícil analisá-los separadamente.

Umberto Eco (2006, p.63-6) nos fornece um rico exemplo do assunto em questão em Entre a mentira e a ironia. Há nesse livro um estudo acerca do humor na produção literária do escritor Campanile, e é ele justamente o autor do "caso" que comentaremos.

Eco cita, então, a obra Os aspargos e a imortalidade da alma, de Campanile, mais especificamente, o pequeno capítulo intitulado 
"Paganini não repete". O capítulo conta a história de um músico chamado Paganini, que acabara de concluir uma apresentação no salão do "real palácio de Lucca", e está diante de um auditório muitíssimo entusiasmado com a sua performance. Então,

Acalmado o fragor dos consensos e enquanto começavam a circular os refrescos e de todo canto elevava-se um gorjeio admirativo, a marquesa Zanoni, sentada na primeira fila e toda transbordante de rendas venezianas ao redor da peruca amarelada, disse com a voz cavernosa, fixando o concertista com um sorriso que se queria sedutor entre as mil rugas de sua velha pele: "Bis"! Enrolado no fraque, com as madeixas dos cabelos sobre os olhos, Paganini inclinou-se galantemente, sorriu para a velha e gentil dama e murmurou à flor dos lábios: "Sinto muito, marquesa, não poder satisfazê-la. A senhora ignora, talvez, que eu, para defender-me dos pedidos de bis que não acabariam nunca, tenho uma máxima à qual jamais renunciei nem renunciarei: Paganini não repete." (Campanile, apud Eco, 2006, p.64)

Apesar da explicação tão educada e clara, a senhora - já velha e surda - não o ouve. Então, muito efusiva, continua a bater as mãos e a gritar bis "com o pescoço esticado de uma tartaruga" (apud Eco, 2006, p.64). O músico, com firmeza, diz: "Paganini não repete”. A marquesa não compreende e, percebendo que Paganini se preparava para colocar o instrumento em sua caixa, grita, aflita: "Como? E o bis?". Para encurtar a história, o músico é obrigado a repetir no mínimo mais cinco vezes, gritando, que "Paganini não repete".

Fica fácil perceber a fina ironia que permeia todo esse episódio: ao afirmar tantas vezes que "Paganini não repete", o músico, sem perceber, faz justamente o contrário do que afirma, ou seja, ele repete uma, duas, três, inúmeras vezes. Ao mesmo tempo em que o riso acontece, quando ocorre no leitor a percepção do contrário, temos também, sem dúvida alguma, a presença de uma refinada ironia: Paganini, o próprio autor da fala, não percebe a incongruência; trata-se de uma "ironia de situação", como já tivemos a oportunidade de estudar. Logo, temos, retratada nessa cena a espécie de riso 
que nos interessa, a saber, o riso como possibilidade de reflexão. Segundo Eco:

É duvidoso, porém, se rimos das contradições entre linguagem e metalinguagem com que o texto lida, exibindo a própria falência, ou do fato de que no equívoco do texto vemos o nosso próprio equívoco de usuários de uma linguagem que nunca consegue esclarecer se é "meta" ou não. Com Paganini, Campanile está colocando em cena a história de nós próprios, enredados nas tramas da linguagem de que somos falantes. Não percebemos, mas rimos (ou sorrimos) de nós mesmos. (2006, p.72)

Sobre a obra de Campanile, Umberto Eco conclui que, nesse escritor, sobressai-se o "cômico como estranhamento". É interessante perceber que a inferência de Eco em relação à construção do riso no autor objeto de sua análise está bastante próxima da teoria da incongruência proposta por Schopenhauer.

A fim de explicar essa ideia de "cômico como estranhamento", Eco comenta a visão que Campanile expressa sobre a morte:

Campanile extrai da ideia da morte ocasiões para inquietos sorrisos. A começar por aquele seu personagem juvenil que à pergunta "Como vai?", em vez de "Vai-se vivendo", responde: "Vai-se morrendo", e depois explica lucidamente o porquê [...]. (2006, p.108)

Conforme explica Umberto Eco, somos os únicos seres a ter conhecimento de nossa finitude: "somos a única espécie que, não sendo imortal, sabe que não o é" (2006, p.108). Por incrível que pareça, no entender de Eco, Campanile extrai o riso dessa "consciência" humana do fim - de seu fim. Para começar, temos "consciência racional" da morte, todavia, no momento em que nos deparamos com sua "presença concreta", agimos de modo que Campanile considera insensato. Assim, segundo ele:

Quem vai ao funeral de um amigo ou de um parente tem, no fundo, a ideia de que está tratando de uma coisa que não lhe diz respeito 
pessoalmente. [...] Veem-se pessoas estupefatas, como se tivesse acontecido algum fato estranhíssimo que, desde que o mundo é mundo, nunca antes se produzira. [...] Os visitantes pronunciam frases que, mesmo vistas com benevolência, é inevitável que sejam definidas como insensatas. [...] Quanto aos parentes, repetem frases desprovidas de sentido comum: "Não devia morrer"; "Quem poderia imaginar?", e outras, admissíveis somente se o fenômeno da morte estivesse se apresentando pela primeira vez no mundo. (Apud Eco, 2006, p.109)

Logo, se temos consciência de nosso fim, por que nos surpreendemos? Para Eco, "a surpresa seria lógica se, em vez da notícia de que o amigo morreu, tivessem recebido - como um raio em céu sereno - a notícia de que o amigo não morrerá jamais, por toda a eternidade" (2006, p.109-10). Sabedores de que alguém viveria eternamente, então sim - somente nesse contexto - as frases convencionais "Não poderia imaginar!”, "Quem poderia pensar?” ou "Ainda não posso acreditar!” seriam apropriadas.

Por conseguinte, o riso "brota" desse fragmento da obra de Campanile justamente porque esse escritor estaria nos mostrando o "choque", a "tensão" entre os nossos conceitos e a realidade concreta. Analisando o fragmento citado por Eco, percebemos que o escritor "joga" com o conceito equivocado de morte que insistimos em manter aceso em nossas mentes - a morte como algo "novo", "desconhecido" - e a "realidade" sobre esse assunto, que é exatamente o fato de a morte se caracterizar como um acontecimento que, mal ou bem, faz parte de nosso cotidiano.

Assim, em face da morte, o homem não deveria se assustar, porém, se assusta. Não se trata, pois, de um assunto que ele domina apenas no âmbito da razão e se choca ao perceber seu "conceito de morte" negado pelas várias nuanças da realidade concreta. Absolutamente, não. O homem assimila a ideia de morte todos os dias, racional e efetivamente. A realidade previamente conhecida não deveria, portanto, chocá-lo e, contudo, choca. Essa situação é irônica e tal contraste é risível. 
O riso que sobressai desse trecho de Campanile, indo, sem dúvida, ao encontro de Schopenhauer, é, para Eco, "o mais fino, ambíguo e irônico de nossos sorrisos” (2006, p.115). É um riso que caminha ao encontro de Schopenhauer, pois nos coloca frente a frente com nosso engano. É também, com certeza, um riso irônico, uma vez que, na realidade, não estamos enganados, não há equívoco algum: conhecemos a morte, apenas não aceitamos nossa finitude.

Devemos, ainda, a ambiguidade desse riso ao fato de ser ele, obviamente, trágico. Não há dúvida de que existe um esgar de tristeza em todos os risos que buscamos para exemplificar, sobretudo, a teoria de Schopenhauer. Nos esquetes analisados, tanto os policiais incompetentes quanto a líder comunitária ou, ainda, a velhinha personagem de Pirandello - que, já decrépita, se veste como uma mocinha, todas essas cenas provocam risos que expressam nossa precariedade e impotência diante de problemas que sabemos reais.

Minois cita um trecho muito esclarecedor da obra $O$ mundo como vontade e representação. Por meio desse fragmento, é possível entrever a face triste que parece estar sempre atrelada ao riso sério de Schopenhauer:

Com certeza, esse riso é amargo: o que chamamos de gargalhada zombeteira parece mostrar triunfalmente ao adversário vencido quanto os conceitos que ele acalentara estavam em contradição com a realidade que agora se revela a ele. O riso amargo que nos escapa, sem querer, quando descobrimos uma realidade que destrói nossas esperanças mais profundas é a expressão viva do desacordo que percebemos, nesse momento, entre os pensamentos que nos inspiraram uma tola confiança nos homens e na fortuna e a realidade que agora está diante de nós. Aquele que não leva nada a sério, que não crê em nada e que ri de tudo é um patife vulgar, cujo riso não tem sentido. De qualquer forma, só há dois tipos de riso: o tolo e o triste. (Schopenhauer, apud Minois, 2003, p.516)

Portanto, o riso que procuramos valorizar no decorrer de nossa investigação - o riso de Schopenhauer ou o "cômico sério" de Umberto Eco - pressupõe, sempre, uma atitude filosófica. Ele está, 
sem dúvida, ligado aos caminhos tortuosos buscados pelo homem para explicar o mundo. Esse riso possibilita, por conseguinte, que o homem reconheça, veja e apreenda uma "realidade outra", que a "razão séria" - aquela instituída pela "ordem" - não atinge. Logo, é um riso que torna factível a passagem do "pensado", "imposto", "convencionado" ao impensado e ao novo, alargando o saber do sujeito e permitindo, consequentemente, que ele goze de um pouco mais de liberdade. Finalizemos com Minois:

O riso tem um poder revolucionário. Melhor: é um verdadeiro demiurgo, uma potência criativa capaz de ressuscitar os mortos [...]. É o riso de alívio que arruína os esforços terroristas da pastoral oficial; é a divina surpresa, o relaxamento brutal de tensão, no qual os analistas veem uma das principais fontes do riso. Ele exorciza o medo, sem negar a existência do inferno. Teologicamente, poder-se-ia dizer que esse castigo por inversão não é pequeno. Mas o que o torna imperdoável é que ele é apresentado pelo riso. É em torno do riso que a divisão e o confronto se efetuam. [...] O riso aparece como uma arma suprema para superar o medo. Quem ri do inferno pode rir de tudo. O riso - eis o inimigo - para aqueles que levam tudo a "sério". (2003, p.275) 



\section{5}

\section{CONCLUSÃo TEÓRICA}

Como afirmamos no decorrer deste livro, as modalidades em questão - ironia, paródia e riso - nos interessam, sobretudo, no que se refere à sua capacidade de desencadear o processo de reflexão no sujeito.

Ainda quando, por meio da interpretação da ironia, o sujeito encontra uma "verdade" próxima ao senso comum, ele chega a isso de maneira diversa. Ou seja, se tal "verdade" foi assimilada após a revelação da ironia, significa que o sujeito precisou pôr em ação o seu saber, raciocinando sobre aquele acontecimento. Portanto, as modalidades estudadas se constituem, sempre, como uma oportunidade de ampliação do conhecimento, uma vez que motivam o sujeito ao uso da razão.

No caso específico da ironia e da paródia - manifestações que se singularizam pela preocupação com a palavra - examinamos os procedimentos literários, os efeitos de sentido ocasionados pelo embate de vozes no texto e, ainda, as formas de edificação dos discursos paródicos e irônicos em textos estritamente literários.

O riso é, nesse aspecto, um acontecimento ímpar, justamente por não se tratar de uma "categoria literária", como ocorre com a paródia e com a ironia, embora essas modalidades (a paródia e a ironia) não estejam restritas ao âmbito da literatura. A configuração 
do riso é diferente. Para Umberto Eco (2006, p.66): “o cômico pertence à esfera dos sentimentos (ou, se quiserem, à psicologia e à fisiologia), portanto, falar dele como de categoria literária é um caso de 'antimetódica construção doutrinal'".

Em razão disso, remontamos à Antiguidade clássica e percorremos os séculos em busca daqueles que estudaram o risível, e encontramos críticos literários e cientistas, mas sobretudo filósofos. Deparamo-nos com teorias as mais variadas, conforme mostramos nos capítulos anteriores. Após esse percurso de estudo sobre o riso, a paródia e a ironia, é interessante perceber os pontos de contato entre essas modalidades e, ainda, os aspectos que, ao contrário, as individualizam.

A primeira semelhança que comentaremos diz respeito ao fato de que esses três "acontecimentos" foram - e continuam sendo muito temidos. Hegel, para citar apenas um opositor, considerou a ironia insuportável. Para ele, "o irônico rebaixa tudo, destrói tudo e não tem caráter: o irônico, como individualidade genial, consiste no autoaniquilamento de tudo o que é soberano, grande e nobre" (apud Minois, 2003, p.512).

Em seu julgamento sobre a ironia, Hegel salienta, pois, o pedantismo e o sentimento de superioridade, supostamente presentes no ironista. Ele reforça, ainda, a ironia como um tipo de atitude de negação plena, como um discurso essencialmente niilista. George Minois cita, ainda, outra passagem da obra Curso de estética, de Hegel:

essa é a significação geral da divina e genial ironia, dessa concentração em si mesmo de um EU para quem todos os elos se romperam e que só pode viver nas delícias do regozijo de si. A invenção dessa ironia deve-se ao senhor Friedrich von Schlegel e a muitos outros que, na sequência, retomaram a tagarelice e ainda hoje a repisam em nossos ouvidos. (Apud Minois, 2003, p.512)

Como se vê, Hegel tinha aversão à ironia. Conforme estudamos anteriormente, o riso também ganhou adversários ferrenhos, desde a Antiguidade até os dias atuais. De acordo com Minois, 
No período mais arcaico o riso é, antes de tudo, uma expressão agressiva de zombaria e de triunfo sobre os inimigos. A zombaria faz parte das invectivas rituais; é uma arma, uma ameaça, eficaz e temerosa, usada pelos bons e pelos maus. Os livros históricos fervilham de exemplos: "tu serás a risada dos povos", "a risada dos vizinhos", "a risada dos insensatos" [...]. (2003, p.117)

Não podemos perder de vista que, já no século XVIII, encontramos Thomas Hobbes, que vê no riso, sempre, a manifestação da superioridade e do orgulho daquele que ri. Logo, a proximidade entre o riso e a ironia nesse aspecto é legítima: o ironista e aquele que ri já foram considerados - e ainda o são - exibidos, vaidosos, diabólicos, indivíduos prontos para escarnecer e humilhar qualquer um que cruze seu caminho. Segundo Minois,

O diabo é ironista porque é um grande ilusionista, o grande mágico. Nada existe verdadeiramente, nada é realmente sério, tudo se presta ao riso. O ironista termina por flutuar entre o real e o irreal, entre o autêntico e o virtual. Ele esvazia o conteúdo objetivo e reduz o mundo a palavras. (2003, p.436, grifos nossos)

François-Marie Arouet, mais conhecido como Voltaire (1694-1778), exerceu em sua época, sem dúvida, esse papel de gênio satírico - logo, temido - e de inimigo implacável de todas as formas de manifestação dos dogmatismos. Na obra Contos e novelas: Voltaire, encontramos o seguinte a respeito desse filósofo:

Foi o brilhante vulgarizador das ideias inglesas nas suas Cartas filosóficas. E o mais impiedoso demolidor dos abusos do antigo regime, dos dogmas da religião revelada no seu dicionário portátil. É aí, na polêmica, que se depara o verdadeiro gênio de Voltaire; aí ele brinca, se irrita, faz prodígios de espírito. Pode-se não apreciar as suas ideias, pode-se mesmo detestá-las, mas é impossível não se inclinar diante de sua arte endiabrada e fremente. (2005, p.69)

Segundo Minois, "aos olhos de Voltaire, a zombaria é a melhor aliada da razão, o grande meio de diminuir o número de maníacos, 
fanáticos, entusiastas, sectários: ele os mata pelo ridículo" (2003, p.430). Estamos, com certeza, diante de um riso crítico, de negação às verdades absolutas, de um riso de deboche às ideias preconcebidas. Podemos compreender, pois, as causas que explicam tanto temor e ódio dirigidos a esse filósofo. Ainda em Contos e novelas: Voltaire, lemos:

Fez, com efeito, de seu riso não mais a leve espuma de que fala em uma de suas cartas, e que ferve na taça erguida, mas a máquina infernal que se colocou no velho mundo de antes de 1789 como uma carga de dinamite e o fez saltar pelos ares. $\mathrm{E}$ isso, mais seguramente por certo do que Rousseau com toda a sua eloquência proletária e sua dialética feroz. (2005, p.70)

É compreensível, pois, que aos discursos caracterizados pela ironia e pelo riso tenha-se associado a ideia de orgulho e vaidade, e que os autores que dela lançaram mão, como Voltaire, tenham sido odiados e temidos. Entretanto, o que nos interessa é justamente validar essas modalidades como procedimentos sérios, capazes de ampliar o conhecimento, propondo novas significações para o mundo pelo uso da razão.

A paródia, por sua vez, também não se manteve nem um pouco distante das críticas. Como dissemos no capítulo em que tratamos dessa modalidade, os parodistas foram acusados de não ser originais e de produzirem uma arte parasitária e derivativa. Tanta afetação dirigida à paródia só pode ter um motivo: ela é uma espécie de recusa, como o riso e a ironia.

Não podemos esquecer, contudo, que, recusando, a paródia reafirma; negando, prolonga a vida do texto parodiado: e essa é sua maior ironia. Sobre ser a paródia uma modalidade tão temida quanto a ironia e o riso, basta dizer que o próprio Voltaire - paladino da zombaria - não suportou ser parodiado. Aproveitou-se de sua influência e conseguiu proibir paródias de algumas de suas peças, pois o filósofo as considerava "sátiras odiosas" (Minois, 2003, p.432). 
A relevância do sujeito em textos ou situações caracterizados pela ironia, paródia ou pelo riso é, com certeza, o ponto de contato mais importante entre essas modalidades. Tais textos, marcados por uma natureza dissonante e contraditória, clamam pela participação do leitor/receptor na construção do sentido e essa é, indubitavelmente, uma forte semelhança entre essas modalidades.

Pensemos, em primeiro lugar, nos textos paródicos e irônicos. É curioso constatar que neles, quase sempre, o leitor não é apenas convidado a participar da construção do sentido, mas sim convocado. Como vimos, caso o sujeito não colabore na estruturação do significado, não acessará o "sentido pleno" proposto - e tornado implícito - por essas categorias.

Tanto a ironia quanto a paródia são caracterizadas por apresentarem uma duplicidade em sua estrutura. Assim, o receptor desses textos deverá estar atento a fim de perceber esses "discursos" que se encontram em tensão, caso contrário, o "sentido maior" não se estabelecerá. Para Linda Hutcheon,

A ironia é, por assim dizer, uma forma sofisticada de expressão. A paródia é igualmente um gênero sofisticado nas exigências que faz aos seus praticantes e intérpretes. O codificador e, depois, o descodificador, têm de efetuar uma sobreposição estrutural de textos que incorpore o antigo no novo. A paródia é uma síntese bitextual, ao contrário de formas mais monotextuais, como o pastiche, que acentuam a semelhança e não a diferença. (1985, p.50)

Desse modo, ironia e paródia apresentam uma "voz" explícita, superficial, e outra implícita, que aparece como pano de fundo. Em relação a essa segunda voz implícita, o sentido provém do contexto, no caso da ironia, e do próprio texto, no caso da paródia. No entender de Hutcheon, "O sentido final da ironia ou da paródia reside no reconhecimento da sobreposição desses níveis” (1985, p.51).

Para que se entendam melhor as semelhanças entre ironia e paródia, faz-se necessário retomar algumas palavras ditas anteriormente acerca da ironia. Assim, foi comentado que essa categoria 
possui duas importantes funções: uma semântica contrastante, e outra pragmática avaliadora.

A primeira deve ser entendida como um assinalar de diferenças de sentido; desse modo, essa função (a semântica contrastante) se origina na sobreposição de contextos semânticos - o que é afirmado e o que é intencionado pelo produtor daquele discurso. A segunda função, geralmente esquecida, segundo Hutcheon - por parecer óbvia demais -, é, no entanto, extremamente importante, pois estabelece a avaliação, o julgamento, propriedades inerentes a quase todas as manifestações irônicas.

Como vimos no capítulo 2, não se pode perder de vista que essas funções, na maioria dos casos, se complementam: é comum, pois, que o ironista parta da oposição semântica e chegue à atitude avaliadora pretendida. Entretanto, de acordo com as intenções do produtor do texto, uma dessas funções pode ser trabalhada de maneira a se tornar mais saliente do que a outra. Os dois casos comentados aqui estão exemplificados no capítulo sobre as funções da ironia.

Dito isso, é possível estabelecer uma semelhança essencial entre a paródia e a ironia, que está relacionada à importância do sujeito como "receptor ativo": ambas marcam a diferença por meio da sobreposição de contextos. De acordo com Hutcheon,

Dada a estrutura formal da paródia, [...] a ironia pode ser vista em operação a um nível microcósmico (semântico) da mesma maneira que a paródia a um nível macrocósmico (textual), porque também a paródia é um assinalar da diferença, e igualmente por meio de sobreposição (desta vez de contextos textuais, em vez de semânticos). (1985, p.74)

Logo, ambas - ironia e paródia - sinalizam o discurso sub-reptício em detrimento do discurso mostrado, explícito, fornecido "tranquilamente" ao leitor; isso significa que o receptor de qualquer mensagem sentirá mais facilidade em apreender um sentido ou uma voz que esteja na superfície do texto, o que não é o caso da paródia e da ironia. 
No caso de textos irônicos e paródicos - e essa é a principal semelhança entre essas categorias -, o leitor precisa decifrar as marcas deixadas pelo produtor na "superfície" desses textos a fim de acessar um sentido "oculto", velado, que, muitas vezes, tende a negar o sentido superficial.

Umberto Eco, em seu livro intitulado Entre a mentira e a ironia, também salienta a importância da participação do receptor na edificação do significado. Ele faz o seguinte comentário acerca do escritor Campanile, objeto de seu estudo nessa obra: "Hoje se compreende melhor a natureza do cômico campaniliano, à luz de tantos estudos de pragmática da comunicação, como uma estratégia fundada sobre o implícito que exige mútua cooperação dos falantes [...]” (2006, p.78, grifos nossos).

Umberto Eco cita, ainda, um diálogo presente na obra Tragedie, de Campanile, a fim de exemplificar o que comentamos anteriormente: "- Com licença, eu sou Pericle Fischetti. E o senhor?" “- Eu, não” (apud Eco, 2006, p.78). Como se vê, trata-se de um ótimo exemplo de cooperação ausente, que acaba ocasionando o riso.

No caso da ironia, vimos que a estudiosa Linda Hutcheon (2000, p.28) chega mesmo a questionar a nomeação do "ironista": não seria ele o receptor/interpretador da ironia? Afinal, o receptor de um texto é justamente aquele que irá - ou não - desvendar sua estrutura dicotômica e lhe atribuir um sentido irônico. Segundo Hutcheon, "esse processo produtivo, ativo, de atribuição e interpretação, envolve ele mesmo um ato intencional, de inferência" (2000, p.28). É preciso supor, inclusive, alguns interpretadores considerando um texto irônico "ao pé da letra", ou seja, lendo-o em seu sentido literal, sem se dar conta de sua ambivalência.

Conforme comentamos, em relação à paródia, o leitor não tem menos trabalho. Ele deve perceber a duplicidade que sustenta o texto paródico, caso contrário, perderá parte relevante de sua significação. Logo, também não é possível pensar em paródia sem a participação essencial do leitor, que empresta seu saber ao texto e 
aciona seu conhecimento de mundo a fim de localizar a dissonância subjacente àquele discurso.

Seguindo esse raciocínio, fica explicada a razão em que se baseia Hutcheon quando afirma que textos paródicos e irônicos assinalam a diferença - a ironia, uma diferença semântica, e a paródia, textual. Sendo assim, a paródia se aproxima da ironia sobretudo graças à função semântica contrastante, que se faz sempre presente na ironia, e que pode aparecer também na paródia. Conforme a mesma estudiosa,

Devido a essa semelhança estrutural, [...] a paródia pode servir-se, fácil e naturalmente, da ironia como mecanismo retórico preferido e até privilegiado. A patente recusa pela ironia da univocalidade semântica equipara-se à recusa pela paródia da unitextualidade estrutural. (1985, p.74-5, grifos nossos)

Por conseguinte, a proximidade estrutural entre paródia e ironia é tanta, como se pôde observar, que, não raro, a paródia utiliza a ironia para cumprir seus propósitos de acordo com o contexto. Isso poderá ser observado no capítulo de análise das obras. Ainda para Hutcheon:

Trata-se de um resultado da dupla estrutura de sobreposição comum da paródia e da ironia, que não obstante, assinala paradoxalmente diferença - em termos semânticos ou textuais. Esta dependência diferencial, ou mistura de duplicação e diferenciação, quer dizer que a paródia funciona intertextualmente como a ironia funciona intratextualmente: ambas ecoam para marcar mais diferença que semelhança. (Hutcheon, 1985, p.84)

A semelhança que notamos entre ironia e paródia - a relevância da participação do sujeito na criação do sentido - também se verifica em relação ao riso. Assim, o tipo de riso valorizado pelo presente trabalho, aquele marcado pela contradição, ambiguidade e incongruência, também convoca a participação do receptor. Ora, uma vez constituído pela tensão, pelo elemento dual - e eis aqui mais 
uma semelhança com a ironia e a paródia -, esse riso carece de um sujeito que atualize suas "feições opostas", reconhecendo a pluralidade motivadora do sentido. Para Ângela Maria Dias, estudiosa a que já nos referimos anteriormente, "talvez pudéssemos sugerir que a percepção da diferença, que o reconhecimento do plural, do turbulento, do desigual, implícitos numa espécie de conciliação, configuram o clima propício à instauração do humor" (1981, p.38, grifos nossos).

Não podemos deixar de citar aqui, mais uma vez, a teoria do riso proposta por Jean Paul, para quem o cômico não se localiza no objeto, mas sim no sujeito. Jean Paul salienta, por conseguinte, a ação do sujeito, que direciona seu conhecimento a uma situação específica, produzindo o cômico.

Estudamos também Baudelaire e vimos que, além de valorizar o sujeito como "produtor" do riso, para ele, esse "acontecimento" o riso - jamais é desprovido de intenção. Desse modo, para Baudelaire, assim como não se "faz" ironias e paródias à toa, o riso também é marcado, sempre, por um propósito. Ora, parece que salientar a ação cognitiva do sujeito pressupõe, de fato, uma intenção.

Como foi dito antes, essa discussão acerca da importância do sujeito nos remete, sem dúvida alguma, à problemática da ironia romântica. Pensando de maneira prática nas teorias de Jean Paul e de Baudelaire acerca do riso, temos o seguinte: do primeiro, como já tivemos a oportunidade de saber, nos chega o legado da supremacia do sujeito, e, do segundo, aprendemos, sobretudo, que esse sujeito - valorizado como "produtor do riso" - sempre que põe seu saber em movimento, o faz visando atingir um objetivo específico.

Bem, o que é a ironia romântica senão - conforme vimos na seção do capítulo 2 que leva seu nome - a primazia do indivíduo (criador) em relação à sua obra (objeto criado)? A ironia romântica se caracteriza, sempre, por um sujeito "intrometido" na sequência dos fatos narrados, promovendo a ruptura da narrativa, a fim de colocar em prática a sua intenção. Trata-se, pois, segundo Volobuef (1999, p.90-1), da "ascendência do autor em relação à obra". O acontecimento do riso em Jean Paul e Baudelaire se configura de 
modo muito semelhante: é marcado pela supremacia do sujeito em relação ao objeto do riso. Logo, no entender desses filósofos, uma situação jamais é risível em si mesma: ela aguarda a ação cognitiva de um sujeito.

É válido reiterar que Jean Paul vive o intenso "Sturm und Drang", movimento pré-romântico alemão cuja marca fundamental é justamente a ênfase na força criadora do indivíduo livre. Por conseguinte, é até mesmo natural que esse momento literário se caracterize por inúmeras ocorrências de ironia romântica e, ainda, que no âmbito filosófico se sobressaia a teoria do riso que acabamos de comentar.

É legítima, portanto, a proximidade entre o riso de Jean Paul e Baudelaire - e certamente de Schopenhauer - e a ironia romântica. Quando retomamos a teoria de Schopenhauer, então, as semelhanças se tornam ainda mais evidentes. Basta que recordemos que esse filósofo propõe o entendimento do riso como fruto de uma incongruência. Ora, a ironia romântica, ela mesma, não toma parte em um jogo sempre interessante de contrastes? Entre o que o leitor supõe encontrar na obra literária - verossimilhança, ilusão, ficção - e as manifestações de um sujeito que "quebra", por assim dizer, essa expectativa não há uma incongruência?

Dito de outra maneira, as intervenções dessa voz que interrompe o fio narrativo para tecer comentários que muitas vezes não parecem se relacionar com a história narrada nunca são completamente previstas pelo leitor. Nesse sentido, é evidente que, em tais momentos - momentos de ironia romântica -, ocorre um choque ou uma quebra entre o que o leitor imaginava encontrar e o que ele, de fato, encontra. Em face da ironia romântica, não é raro que riamos. Esse riso - que provém da tensão fermentada pela ironia romântica - é, indubitavelmente, o riso de Schopenhauer, inclusive porque nos possibilita a ampliação do conhecimento, como discutiremos no final deste capítulo.

A necessidade de se analisar mais a ironia romântica surge, ainda, de uma semelhança entre esta e a paródia. Como já percebemos, ao falar de ironia, riso e paródia, nos situamos no ter- 
reno da ambiguidade e, nesse sentido, essas categorias sempre se aproximam.

Conforme já dissemos, tanto a ironia - em seu sentido mais comum, ou seja, de um significante para dois significados - como a paródia atuam em dois níveis: um primeiro, superficial, e um segundo, implícito. Em textos irônicos e também em textos paródicos, o sentido final é, pois, resultado do reconhecimento da sobreposição desses dois níveis. Pensando nisso, é pertinente concluir, ao que parece, que todo texto paródico é também irônico, já que o reconhecimento do embate de dois discursos - ou seja, o reconhecimento da ironia - nos leva à paródia. Portanto, a paródia se mostra por meio da ironia.

Se a ironia romântica constitui-se como uma das inúmeras possibilidades de manifestação da ironia em seu sentido mais amplo - um significante para dois significados -, qual é, de fato, a relação entre a paródia e a ironia romântica? $\mathrm{Na}$ verdade, quando o narrador se mostra, abandonando sua posição inicial de "manipulador distante" de suas personagens, estabelece a duplicidade em seu relato.

Isso se dá porque o leitor, no momento em que o narrador projeta sua face, se encontra diante de duas vozes - a de um narrador "objetivo" e a de um legítimo "contador de histórias". Tal é, sem dúvida, a oposição comentada anteriormente: de um lado, o que o leitor presume encontrar (um narrador objetivo) e, de outro, aquilo com que o leitor, de fato, se depara (um legítimo contador de histórias). Não é, de fato, irônico - e risível - que, em meio a tantas tentativas de se instaurar a verossimilhança no relato, surja essa "voz estranha" que, em se mostrando, de certa forma, contribui para desnudar o caráter ficcional da narrativa?

Quando um escritor reflete sobre o processo de construção de seu texto e revela o fazer literário ao leitor, por meio de narradores interventivos - realizando, pois, a ironia romântica -, ele não estará parodiando uma estética literária mais "fechada", mais "clássica", que não prevê esse tipo de intromissão do narrador em seu relato? Parece ser esse um interessante ponto de contato entre a paródia e a ironia romântica. Há, ainda, outro. 
De acordo com Hutcheon, "a ironia romântica, evidentemente, serviu menos para subverter a ilusão do que para criar uma nova ilusão. [...] Esta mesma espécie de ironia torna-se um dos mais importantes meios de criar novos níveis de ilusão" (1985, p.45). Assim, paradoxalmente, ao apontar para fora da narração, o narrador está reforçando, tornando mais autêntica e, portanto, mais verossímil a própria ficção que edifica.

Seguindo esse raciocínio, conforme já foi comentado na seção "Ironia romântica", do capítulo 2, esta conduz o leitor a efeitos de sentido contraditórios: se, por um lado, manifestando-se, o narrador quebra o compromisso de criar a ilusão da realidade ou, em outras palavras, diminui a verossimilhança, por outro, trazendo, muitas vezes, informações do exterior (culturais, históricas, entre outras), para o interior da obra, o narrador cria certa "ilusão de veracidade".

Vimos na seção "O paradoxo da paródia", no capítulo 3, algo muito semelhante em relação à paródia. Essa modalidade, como a ironia romântica, também põe em cena efeitos de sentido dissonantes, porque, ao mesmo tempo, nega e valoriza o conteúdo parodiado. Portanto, é legítimo inferir que a ironia romântica e também a paródia nos conduzem a uma ironia mais profunda. No caso da paródia, as modalidades que estamos estudando estão mesmo emaranhadas: como dissemos, a identificação da ironia nos direciona à paródia e a compreensão mais minuciosa da paródia nos leva, novamente, a uma ironia.

Ainda segundo Linda Hutcheon (1985, p.32), a ironia romântica pode ser considerada um tipo de paródia. Se entendemos a ironia romântica como uma espécie de oportunidade de reflexão e de questionamento sobre o conceito que se tinha de "obra literária", ela se configura como um tipo de paródia. Em outras palavras, se, ao fazer uso das intromissões no relato, o "narrador-autor" põe em xeque o conceito mais clássico de "obra literária", marcado sobretudo pela objetividade ou pela "ausência" do narrador, estamos diante de uma paródia. E, como paródia, cria um efeito de sentido 
irônico: o questionamento e a legitimação do conceito clássico de "obra literária".

Bella Jozef, comentando a obra $O$ jogo da amarelinha, de Cortázar, onde se expressa a problemática da ironia romântica, afirma o seguinte:

O problema do narrar é discutido no próprio processo de realização do conto, como uma tomada de consciência e questionamento, no nível estrutural, do processo de enunciação. O narrador-autor faz uma reflexão sobre o fazer literário, sobre a escrita ficcional, sobre este espaço criador que permite a irrealidade - também em segundo grau - de modo a fazer coexistirem vários planos da ficção e romper a empatia entre o mundo do livro e o mundo do leitor. O exterior inscreve-se no espaço do texto. A partir desse espaço intertextual, os livros se leem e se escrevem, deixando lugar a um texto real que seria a explicação do mundo [...]. (1980, p.63, grifos nossos)

Como se vê, a ironia romântica, realmente, promove a quebra entre o que o leitor supunha encontrar, por meio de sua razão, e o que ele encontra efetivamente. Conforme dissemos, essa quebra de expectativa nos conduz, quase sempre, ao riso: fomos surpreendidos. Ainda que o leitor pressuponha uma intervenção, movido pelo estilo de determinado escritor, ele - o leitor - nunca poderá prever exatamente o teor da intromissão, ou seja, o assunto abordado por ela. Uma vez que é esse um "riso culto" ou um riso aos moldes de Jean Paul, Baudelaire e Schopenhauer, ele nos leva a uma reflexão que varia muito, conforme os objetivos do autor.

Em relação ao que acabamos de comentar, pode ser uma reflexão sobre o próprio conceito de "obra literária". Se pensarmos em O arco de Sant'Ana, cujos fragmentos foram citados na seção "Ironia romântica" do capítulo 2, a voz que se expressa por meio da ironia romântica, como vimos, tece críticas pesadas a seu momento histórico, à burguesia e até mesmo à Revolução Francesa. Trata-se da voz de um eu que já não pode se calar, que necessita emitir seus juízos, suas dores diante de sua sociedade. Nessa obra, a ironia ro- 
mântica revela, pois, os anseios do sujeito histórico da segunda metade do século XVIII, e, consequentemente, cria um novo conceito de "obra de arte", marcada agora pela preeminência do eu.

Portanto, teoricamente, deparado com algo que o surpreende, o sujeito, por meio de uma ação cognitiva, tentará compreender as razões dessa surpresa, os propósitos de tal intervenção do narrador no relato ou, ainda, em que medida o discurso desse "narrador intrometido" se relaciona com a história narrada. Obviamente, em busca de tantas considerações, ocorre a ampliação do conhecimento, instaurada, sem dúvida, pelo indivíduo que "enxerga", nessa ordem, a ironia, a paródia e, consequentemente, experimenta o risível.

Após todas essas reflexões, só nos resta inferir que discursos irônicos, paródicos ou marcados pelo riso são, de fato, exigentes. Tão exigentes que não podemos concebê-los sem o sujeito, que é o "agente catalisador" do riso, da paródia e da ironia. Podemos dizer que, sem a ação cognitiva do sujeito, tais discursos perdem a supremacia, descem à categoria dos discursos simples, objetivos e inofensivos. Pior ainda, na verdade: se a ironia, a paródia e o riso carregam em sua essência um embate de vozes, uma tensão implícita, e estes não são descobertos pelo sujeito, tais discursos não são sequer inofensivos, simplesmente porque é como se não existissem.

Isso sem contar que, para participar da construção do sentido, o sujeito precisa acionar seu repertório ou seu conhecimento de mundo. Tal condição vale para as três modalidades, mas principalmente para a paródia: como reconhecer que se está diante de uma paródia se o texto parodiado não faz parte do repertório do sujeito? Impossível.

Logo, a experiência da literatura exige um texto, um leitor e as inferências a que chega esse receptor de acordo com os sinais deixados pelo produtor daquele texto. Para que possamos compreender o quanto a paródia é exigente nesse aspecto, pensemos também na intertextualidade. Linda Hutcheon argumenta que, no caso da intertextualidade, o leitor é livre para realizar associações entre os textos, mais ou menos ao acaso.

Na paródia, o procedimento é um pouco diferente, uma vez que 
essas aproximações entre textos diferentes ou distantes temporalmente costumam ser controladas. Hutcheon explica:

no caso da paródia, esses agrupamentos são cuidadosamente controlados, orientando "passos inferenciais". Como leitores ou espectadores ou ouvintes que descodificam estruturas paródicas, atuamos também como decodificadores da intenção codificada. (1985, p.35)

Desse modo, enquanto na intertextualidade o leitor associa textos livremente, limitado apenas por seu conhecimento de mundo, um texto paródico requer desse leitor uma leitura mais condicionada e, consequentemente, mais controlada. Por conseguinte, a paródia se constitui como um tipo de discurso extremo nesse sentido, pois suas imposições são deliberadas e inclusive fundamentais para seu entendimento. Para Hutcheon,

a paródia exige que a competência semiótica e a intencionalidade de um codificador inferido sejam pressupostas. Dessa forma, embora a minha teoria da paródia seja intertextual na sua conclusão tanto do descodificador como do texto, o seu contexto enunciativo é ainda mais vasto: tanto a codificação como o compartilhar de códigos entre produtor e receptor são centrais [...]. (1985, p.54)

Assim, se defrontado com uma ocorrência de intertextualidade, o leitor é livre - já que a intertextualidade não deixa de ser um ato de decodificação de textos à luz de outros textos; a paródia é, nesse sentido, mais exigente: deixa propositalmente pistas, marcas, sinais, que devem necessariamente ser seguidos pelo leitor a fim de que o "sentido essencial" seja edificado. A intertextualidade é, pois, mais aberta; a paródia, mais fechada e exigente.

Como dissemos antes, a paródia se mostra pela ironia. Sendo assim, antes de chegar à paródia, o sujeito precisa perceber o jogo irônico entre o texto mais explícito e o "subtexto", ou seja, ele precisa desvelar o que está mascarado pela ironia. Logo, entre as "pistas", "marcas" e "sinais" deixados pelo escritor de uma paródia está, certamente, a ironia, que aguarda ser revelada. 
Pensando dessa forma, parece pertinente dizer que a ironia é também, como a paródia, uma modalidade bastante exigente e controladora. Ora, nesses casos, se o sujeito não desvenda a ironia debaixo de seus olhos, não pode compreender que se encontra diante de um texto paródico.

Assim, embora Hutcheon (2000, p.41) explique, conforme comentamos na seção "A ironia instituindo hierarquias" do capítulo 2 , que a ironia não cria comunidades, mas sim que as comunidades é que existem previamente, possibilitando o acontecimento da ironia, devemos avaliar melhor essa questão. Afinal, no caso da ironia que nos conduz à paródia, será inevitável a formação de dois grupos: o dos que decodificaram a ironia e acessaram a paródia, e o grupo que não se deu conta da dissonância subjacente àquele texto. O passo seguinte pode ser, sem dúvida, a instituição de hierarquias. Esse procedimento pode valer também para os casos em que apenas a ironia esteja envolvida.

Outros tipos de discursos como a imitação, a citação e até a alusão são também confundidos com a paródia. Hutcheon explica que todas essas formas são, entretanto, limitadas se comparadas à paródia. Deve ficar claro, porém, que o reconhecimento da paródia começa também com o reconhecimento de uma intertextualidade:

Ao contrário da imitação, da citação ou até da alusão, a paródia exige distância irônica e crítica. É verdade que, se o descodificador não reparar ou não conseguir identificar uma alusão ou citação intencionais, limitar-se-á a naturalizá-la, adaptando-a ao contexto da obra no seu todo. Na forma mais alargada da paródia que temos vindo a considerar, esta naturalização eliminaria uma parte significativa tanto da forma, como do conteúdo do texto. A identidade estrutural do texto como paródia depende, portanto, da coincidência, ao nível da estratégia, da descodificação (reconhecimento e interpretação) e da codificação. (1985, p.50-1, grifos nossos)

Portanto, diante de um texto paródico, o leitor deve estar atento a todos os sinais. Conforme explicou Hutcheon, a construção da 
paródia e, consequentemente, o acesso à "verdade" que o codificador pretendeu transmitir se inicia com a percepção desses pequenos "passos inferenciais", que podem se expressar por meio de intertextualidades, e, principalmente, pela revelação da ironia. Para Wolfgang Iser,

Os modelos textuais descrevem apenas um polo da situação comunicativa. Pois o repertório e as estratégias textuais se limitam a esboçar e a pré-estruturar o potencial do texto; caberá ao leitor atualizá-lo para construir o objeto estético. A estrutura do texto e a estrutura do ato constituem portanto os dois polos da situação comunicativa; esta se cumpre à medida que o texto se faz presente no leitor como correlato da consciência. Tal transferência do texto para a consciência do leitor é frequentemente vista como algo produzido somente pelo texto. Não há dúvida de que o texto inicia sua própria transferência, mas esta só será bem-sucedida se o texto conseguir ativar certas disposições da consciência - a capacidade de apreensão e de processamento. Referindo-se a normas e valores, como por exemplo o comportamento social de seus possíveis leitores, o texto estimula os atos que originam sua compreensão. Se o texto se completa quando o seu sentido é constituído pelo leitor, ele indica o que deve ser produzido; em consequência, ele próprio não pode ser o resultado. [...] Por esta razão, é preciso descrever o processo da leitura como interação dinâmica entre texto e leitor. (1999, p.9-10, grifos nossos)

O fragmento citado se refere aos textos de uma maneira geral, ou seja, a qualquer ato comunicativo que aguarda, por assim dizer, a chegada de um leitor que irá atualizá-lo. Bem, se todo "modelo textual”, como descreveu Wolfgang Iser, depende da ação cognitiva de um sujeito, uma vez que a situação comunicativa "se cumpre à medida que o texto se faz presente no leitor como correlato da consciência", o que dizer de textos marcados por uma ambiguidade intencionalmente contraditória? É pertinente afirmar, como já o fizemos, que tais textos são muito mais insistentes em relação ao convite para a participação de um sujeito na construção do sentido.

Embora saibamos que o leitor, fazendo uso de sua razão, confe- 
re significado aos textos que lhe chegam, não se caracterizando, pois, como um mero decodificador, textos irônicos e paródicos são, como vimos, mais controladores. A ironia, sobretudo, é mais exigente, pois está na "base" da paródia; afinal, vimos que a paródia se mostra pela ironia. Assim, aparentemente, diante de um "acontecimento" irônico, devemos optar ou pelo literal ou pela "voz" subjacente a esse texto literal.

Sabemos, contudo, que a ironia é sempre um embate de vozes. Assim, cabe a seu receptor caracterizar-se, ou não, como um "receptor ideal”, que é, justamente, aquele capaz de perceber a duplicidade do texto com o qual se depara. Esse receptor deverá reconhecer, ainda, que o "sentido final" pretendido é resultado desse choque entre o literal e o implícito. Desse modo, diante de um texto cuja estrutura é dicotômica, não parece que precisamos simplesmente optar por "isso" ou por "aquilo". Na verdade, a ironia não corresponde ao "sentido velado", mas sim ao embate entre aquilo que nos chega literalmente e esse sentido implícito. Isso significa que o "literal" nos conduz ao "velado" e, então, assimilamos a dissonância. Sabemos que essa "condução" carece, sempre, de um contexto. Exatamente nisso reside a ironia.

Desse modo, ainda que diante de um enunciado irônico o sujeito não tenha necessariamente de optar entre "isso" - o sentido literal - ou "aquilo" - o sentido implícito -, ele terá de notar a tensão inerente a esse discurso. Logo, se a ironia não impõe ao sujeito optar pelo "óbvio" ou pelo "sub-reptício", não deixa, mesmo assim, de ser rigorosa, uma vez que impõe o reconhecimento da contradição entre esses dois sentidos. Conforme dissemos, o que possibilita tal percepção é sempre o contexto. É natural que, em muitos casos, a ironia leve ao riso - o "riso sério", tão mencionado neste capítulo, sempre fruto de uma incongruência.

Portanto, a ironia parece realmente ser o princípio dos "fenômenos" do riso e da paródia. Assim, as modalidades riso e paródia guardam, sempre, em seu cerne, uma pitada significativa de ironia e, por essa razão, é legítimo afirmar que esta se constitui como um fator de estímulo importante para a irrupção do riso e da paródia. 
É fundamental pensar, ainda, que na origem dessas três categorias não temos apenas um contraste. Poderíamos citar inúmeras ocorrências, literárias ou não, marcadas por uma estrutura dissonante, mas que, de fato, não se constituem como enunciados irônicos. Bem, seguindo nosso raciocínio, se não há ironia, provavelmente não haverá paródia ou riso. Se nem toda oposição se configura como uma ironia, o que especificaria um contraste irônico? Que espécie de característica, associada a ideias dissonantes, produziria a ironia?

Olhamos para uma parede e percebemos que metade dela foi pintada de branco e a outra metade, de preto: não se trata, obviamente, de uma ironia. Numa discussão acirrada sobre um tema polêmico, vemos pessoas diferentes defendendo, ao mesmo tempo, opiniões contrárias e isso, definitivamente, não se constitui como uma ironia. Supondo que o tema da discussão, por ser polêmico, nos levasse principalmente a duas possibilidades opostas de "solução”, seria possível, ainda, que uma mesma pessoa, mais diplomática, apontasse aspectos positivos inerentes às duas possibilidades contraditórias entre si: isso também não seria necessariamente um caso de ironia.

Entretanto, se essa pessoa diplomática, conhecida justamente por sua reserva e discrição em assuntos controversos, defender de modo obstinado uma das possíveis soluções, atacando com veemência a outra possibilidade, então sim, podemos estar diante de uma ironia. Ou, pelo contrário, se um sujeito sempre acostumado a tomar partido, a posicionar-se claramente, age de modo a ficar "em cima do muro", também aqui é provável que estejamos observando uma situação irônica. O que parece, pois, tornar singular o contraste irônico é justamente a quebra da expectativa, a surpresa.

Portanto, refletindo sobre tais indagações, chegamos a uma possibilidade de resposta que, de fato, vem ao encontro das ideias principais estudadas na presente pesquisa. Realmente, o "surpreender-se" parece ser também o "ato" que une as três modalidades analisadas neste livro. Admiramo-nos diante da ironia "situacional", como vimos, e também frente à ironia "verbal": é 
sempre curioso "ver", na fala ou na escrita, um sentido oculto aparecer subitamente. Sensação semelhante nos toma quando estamos frente a frente com uma paródia ou com uma ocorrência de ironia romântica: sentimo-nos agradavelmente espantados. E o que dizer do riso? Ainda que possua seu viés trágico, o sentimento do contraste é tão prazeroso que explodimos em um movimento que nos chacoalha as entranhas.

Bem, a sensação de "assombro", o admirar-se, o surpreender-se - efeitos provenientes do reconhecimento da ironia, da paródia e do riso -, estão certamente associados à função estética da literatura. Como sabemos, a literatura se opõe a qualquer tipo de "acontecimento" caracterizado por uma função utilitária ou imediatista, que visaria, por exemplo, "explicar", "ordenar", "informar", entre outras. Ao contrário, os textos literários devem ser valorizados por ocasionarem o prazer estético, que é, em linhas gerais, o prazer de acessar uma realidade que não nos chega de modo habitual ou direto, mas sim artisticamente, por meio da ficcionalidade, plurissignificação e subjetividade.

Compreendida essa realidade que, por não "chegar" de modo imediatista, exige esforço intelectual do sujeito, chegamos a outra função interessante da literatura: a catártica. Ela está associada à função estética, uma vez que corresponde à purificação, ao alívio proporcionados pela arte, de modo geral. Georges Minois fala sobre a presença do riso catártico nas comédias latinas. Para ele, tal riso produzia um alívio coletivo: "a segunda ilustração da função catártica do riso na comédia latina é a contestação do poder despótico do pater familias, zombado, ridicularizado no papel de velhos avarentos e lúbricos que monopolizam o dinheiro e as mulheres" (2003, p.101). Trata-se, assim, de um riso de transgressão e, consequentemente, de alívio.

Como se vê, as funções estética e catártica atribuídas à literatura podem ser também concedidas às nossas modalidades de estudo. Conforme repetimos exaustivamente, a ironia, a paródia e o riso convidam o sujeito a participar da construção do sentido. Ao se entregar à atividade de desvendar tais discursos, o sujeito será bem- 
-sucedido caso perceba a estrutura irônica desses textos. A surpresa sentida pelo indivíduo que chega à ironia inerente a alguns enunciados se aproxima muito da significação do prazer estético e da catarse - funções da própria literatura.

A fim de percebermos o quão interessante é essa ligação, reflitamos sobre o que comenta Luiz Costa Lima em sua obra Mímesis: desafio ao pensamento, publicada em 2000. Esse estudioso fala sobre o "engano" da arte. Segundo ele, dois sentimentos contraditórios invadem aquele que se propõe a assistir a uma peça teatral, por exemplo. Assim, para se experimentar uma sensação de piedade é necessário que se tenha a impressão de que sucede uma ação que é dolorosa ou destrutiva; entretanto, como se sabe, no palco trágico, nada é destruído. O receptor sente, assim, por um lado, a dor da piedade pelos sofrimentos do protagonista e, por outro, o prazer catártico por sentir uma dor que, no plano da realidade, não existe. A mímesis - entendida como representação artística - supõe, portanto, a experiência de um equívoco profundo.

Ora, por tudo que discutimos, é coerente afirmar que, no momento em que se defronta com enunciados irônicos, paródicos ou marcados pela estrutura incongruente do "riso sério", o sujeito também experimenta a sensação de um equívoco profundo. Logo, a problemática da contradição está inserida também no próprio conceito de mímesis; afinal, nos entregamos à catarse apesar da consciência de que estamos diante da ficção.

Portanto, é legítimo afirmar que a ironia, a paródia e o riso podem ser pensados como o meio que a arte encontra para se autorrepresentar. Nesse sentido, as características e funções da literatura se ajustam perfeitamente às categorias analisadas. Podemos afirmar inclusive que a ironia, a paródia e o riso se constituem como "micro-mímesis", ou seja, representações artísticas menores inseridas na "mímesis maior", que seria a própria obra literária. Segundo Antonio Candido,

A criação literária traz como condição necessária uma carga de liberdade que a torna independente sob muitos aspectos, de tal maneira 
que a explicação dos seus produtos é encontrada sobretudo neles mesmos. Como conjunto de obras de arte a literatura se caracteriza por essa liberdade extraordinária que transcende as nossas servidões. Mas na medida em que é um sistema de produtos que são também instrumentos de comunicação entre os homens, possui tantas ligações com a vida social, que vale a pena estudar a correspondência e a interação entre ambas. (2000, p.163, grifos nossos)

Por conseguinte, a literatura ou o conjunto de obras literárias se constitui como uma possibilidade de redenção do pensamento quase sempre aprisionado nos limites da convenção. Se pensarmos na ironia, na paródia e no riso como "micro-mímesis", encontramos exatamente aquilo que temos repetido no decorrer de todo este trabalho: essas modalidades contribuem para alargar o conhecimento, uma vez que nos permitem enveredar por caminhos não previstos pela ordem estabelecida, vislumbrando novas possibilidades de verdade. Conforme explica Aristóteles,

Além disso, sendo agradável aprender e admirar, tudo o que a isto se refere desperta em nós o prazer, como, por exemplo, o que pertence ao domínio da imitação, como a pintura, a escultura e a poesia, numa palavra tudo o que é bem imitado, mesmo que o objeto imitado não careça de encanto. De fato, não é este último que causa prazer, mas $o$ raciocínio pelo qual dizemos que tal imitação reproduz tal objeto; daí resulta que aprendemos alguma coisa. (Aristóteles, [19--], p.87-8, grifos nossos)

As palavras de Aristóteles vêm ao encontro de nossas ideias. No entender desse filósofo, o sujeito experimenta uma sensação prazerosa quando, exercitando sua razão, assimila algo novo. Sente-se, então, muito bem; afinal, algo dependeu exclusivamente de sua ação cognitiva para existir. Ainda que não chegue a uma "verdade" inédita, movimentou seu saber, legitimando sua condição de "ser" humano, de "ser" racional. Ele - o sujeito - é o criador, e agora diante de sua criação - é tomado por certa vaidade. Esse é justamente o prazer estético que comentamos. 
Assim, a sensação de deleite e de "surpresa agradável" pode ser fruto do entendimento da obra literária em toda a sua amplitude, ou pode, ainda, acontecer gradualmente, nos momentos em que o sujeito se depara com a ironia, a paródia ou o riso. Nesse caso, a assimilação daquilo que chamamos "micro-mímesis" ou "microrrepresentações" conduzirá o leitor ao sentido mais essencial de toda a obra.

Tais categorias, a saber, a ironia, a paródia e o riso, se configuram, pois, como as "vias" por meio das quais a arte representa a si mesma. De fato, desvendar esses artifícios de que a literatura faz uso constitui uma experiência de acesso ao impensado, ou seja, àquilo que se afasta das concepções impostas e aceitas irracionalmente. Em relação ao riso, por exemplo, Verena Alberti afirma algo que vale, sem dúvida, para a ironia, paródia e, conforme o raciocínio que estamos tecendo, também para a própria literatura: "saber rir [...] é tornar-se Deus, experimentar o impensável, ou ainda sair da finitude da existência" (1999, p.23).

Portanto, como insistimos no decorrer de todo este capítulo, ironia, paródia e riso, agora entendidos como representações da própria arte literária, são modalidades que viabilizam o crescimento intelectual do indivíduo. Afinal, oriunda de um "ser histórico", a literatura está sempre calcada na realidade e, desse modo, atua na formação do homem. Esse avanço em direção ao entendimento de nossa "natureza humana" é alcançado, vale a pena reiterar, mediante a transgressão. Riso, paródia e ironia - vistos como representações da própria literatura - são categorias, portanto, que nos convidam a transcender nossa realidade chata, porque previsível, conhecendo realidades diversas.

Segundo Verena Alberti, "tal concepção é [...] importante, porque estabelece o caráter indispensável desse movimento livre do entendimento, sem o qual nada é criado. Ou melhor, sem o qual não há filosofia nem poesia" (1999, p.171-2, grifos nossos). Nesse sentido, tanto o riso, como a ironia e também a paródia são tipos de discursos que se singularizam justamente por sua força criadora e por sua capacidade de engendrar o novo. 
Seguindo esse raciocínio, quando dissemos que essas categorias são exigentes, não pretendemos confirmar a ideia errônea de que as modalidades a que nos dedicamos se especificam por estabelecer, preceituar, sempre, uma única "verdade", de modo autoritário. Tal constatação dissolveria, por assim dizer, a inferência de que as categorias estudadas ampliam o entendimento, até porque se caracterizam como "microrrepresentações" da literatura.

Obviamente, como todo ato de comunicação - falada ou escrita -, a ironia, a paródia e o riso veiculam, sempre, um ponto de vista. Todavia, a "verdade" proposta por esses discursos, como vimos, sempre surpreende. Em primeiro lugar porque representam a própria arte e nesse sentido são organizados de modo controlado para quebrar nossas expectativas, lançando-nos longe do trivial. Assim, caracterizados como as vias por meio das quais a literatura se autorrepresenta, a ironia, a paródia e o riso tendem a gerar o novo.

Mesmo que a mensagem "arquitetada" por essas categorias não seja completamente inédita - até porque isso não parece ser possível -, ainda assim, por se tratarem de discursos artísticos, pedem a colaboração do sujeito na organização do sentido; então, como a razão foi acionada, já é possível entrever uma possibilidade de crescimento.

É certo que essas modalidades, sobretudo a "ironia pura", podem ser usadas de modo autoritário; nesse caso, porém, a ironia seria arbitrária como qualquer ato comunicativo pode ser. $\mathrm{O}$ importante é perceber que, de fato, não é um traço peculiar a essas modalidades serem identificadas aos discursos autoritários. Na realidade, a própria estrutura dicotômica - marca essencial desses textos - já parece criar mais de uma possibilidade de leitura. Portanto, como arte, o riso, a paródia e a ironia transcendem a "ordem natural” da existência, estimulando o sujeito à reflexão.

Se há uma espécie de imposição que une e especifica esses discursos, ela diz respeito unicamente à convocação obstinada ao sujeito para que participe ativamente da construção do sentido. Conforme dissemos, o sujeito é o "agente catalisador" dessas mo- 
dalidades. Logo, parece ser procedente dizer, como já afirmamos, que, sem o empréstimo do saber do sujeito, não há irrupção da ironia, da paródia ou do riso.

Tais modalidades, estimulando o indivíduo a raciocinar para contribuir com o "surgimento" do significado, reforçam, portanto, o potencial do sujeito como força criadora. Esse é, sem dúvida, o aspecto que torna ainda mais estreito o laço entre a paródia, a ironia e o riso. Além disso, esses discursos, ao enfatizarem a capacidade criadora do sujeito, se aproximam da própria função da literatura, tornando-se, como vimos, caminhos privilegiados por meio dos quais a arte literária se autorrepresenta.

Nesse sentido, a ação cognitiva do sujeito é decisiva. A oportunidade de ampliação do conhecimento criada pela literatura e pelas modalidades em questão é, sem dúvida, maravilhosa. A paródia, a ironia e o riso, como construções edificadas artisticamente, podem ser vistas, inclusive, como motivadoras de uma teoria do conhecimento.

Contudo, há o sujeito... Tão valorizado e, quase sempre, pouco disposto ao exercício da razão. Inserido numa sociedade imediatista, é coagido a aceitar e a reproduzir ideias prontas, desprovidas de qualquer fundamento racional. Como teremos a oportunidade de ver em $O$ cavaleiro inexistente, de Ítalo Calvino, o homem atual é exaustivamente convidado a dissolver-se na grande "massa", desistindo daquelas características que o individualizam em meio ao todo.

O sujeito que somos não parece estar consciente dos caminhos que levam ao conhecimento. Em sua mente, não há harmonia entre os saberes; tudo é tragicamente compartimentado: de um lado, a "experiência", do outro, o "saber intelectual" e, de outro, ainda, o "autoconhecimento". Esse indivíduo não sabe que a arte o representa: desconhece, portanto, que, através desse "saber intelectual", pode encontrar a si mesmo, pode deparar-se, em qualquer "página", com sua essência perdida.

Do passo seguinte, então, ele está bem distante: sua mudança e a consequente mudança de sua experiência concreta. Sim, porque, 
ao contrário do que se pensa, não são os dogmas religiosos - indiscutíveis e inquestionáveis - os causadores da reforma. Não, absolutamente. A construção de indivíduos éticos e conhecedores da realidade a seu redor só é possível por meio da razão e não se faz "da noite para o dia". Além de nossa sociedade ser imediatista, a razão não está em alta.

É preciso, pois, ser ousado para fazer uso da razão, ainda hoje. A razão desmistifica, esclarece, desvenda, revela, ilumina o que não se podia enxergar pela ausência de luz. A razão - e somente ela permite que olhemos para o mundo, para as pessoas e para nós mesmos como se fosse a primeira vez. Enveredando por esse caminho, apreendemos o sentido primeiro das coisas e nos tornamos mais livres. Pelo menos acreditamos nisso, até a chegada sorrateira daquele "riso irônico", consequência do fracasso de nossa razão. Ele costuma ser o indício de que é preciso rever, investigar, transformar-(se) novamente. Esse é o movimento sinalizador da presença de vida. Nascer não é, de fato, suficiente.

Para pôr em prática nossa condição de seres humanos, logo, necessitamos pensar. E a literatura - representada em nossa pesquisa pela ironia, paródia e riso - se constitui como um excelente caminho, pois,, reivindicando o exercício da razão, estimula o desenvolvimento intelectual e ético do sujeito.

Se a literatura anda na contramão de uma sociedade "engessada", nós - os sujeitos de hoje - estamos na contramão do conhecimento. Carecemos, portanto, da ousadia que nos fará transcender o universo das coisas prontas e encontrar o novo. É necessário, todavia, antes de mais nada, vontade. Finalizemos com as palavras interessantes, porém um pouco radicais, de Georges Minois:

Com certeza, o riso dos filósofos não transformou o Antigo Regime. No domínio das mentalidades, o efeito da derrisão é, às vezes, desesperadamente nulo. Mas será que o riso sozinho consegue derrubar um preconceito, uma superstição, uma bobagem, uma crença estúpida? Séculos de zombaria não eliminaram nem a astrologia nem os fundamentalismos religiosos. 
É porque é preciso um mínimo de espírito para apreciar o espírito, e aqueles que o têm já são convertidos; para os outros, o muro da estupidez constitui uma blindagem impermeável à ironia. Portanto, a ironia é para uso interno; ela mantém o bom humor, permite suportar a estupidez e absorver os golpes baixos da existência. "A vida é uma tragédia para aqueles que sentem e uma comédia para aqueles que pensam", diz bem, a propósito, Horace Walpole. (2003, p.435, grifos nossos) 



\section{6}

\section{DISSONÂNCIAS LITERÁRIAS}

\section{Reinvenção}

A vida só é possível

reinventada.

Anda o sol pelas campinas

e passeia a mão dourada

pelas águas, pelas folhas...

Ah! tudo bolhas

que vêm de fundas piscinas

de ilusionismo... - mais nada.

Mas a vida, a vida, a vida, a vida só é possivel reinventada.

Vem a lua, vem, retira

as algemas dos meus braços.

Projeto-me por espaços

cheios da tua Figura.

Tudo mentira! Mentira

da lua, na noite escura. 
Não te encontro, não te alcanço...

Só - no tempo equilibrada,

desprendo-me do balanço

que além do tempo me leva.

Só - na treva,

fico: recebida e dada.

Porque a vida, a vida, a vida,

a vida só é possível

reinventada.

Cecília Meireles

\section{"O duplo", de Dostoievski, e o emaranhado de vozes desarmônicas}

Se tu viesses a olvidar-me

Eu jamais te olvidaria!

Venha lá o que vier,

Deves também recordar-me.

Dostoievski

"O duplo", de Dostoievski, traz a história do senhor Goliádkin, um modesto empregado de repartição pública que, possivelmente no dia mais fatídico de sua vida, encontra uma pessoa que é a sua cópia perfeita. Esse acontecimento desencadeia uma série de neuroses que culminam em sua loucura e consequente internação em um manicômio.

Durante a leitura - que, ao invés de causar deleite, inquieta -, o leitor tem, então, acesso à aflitiva mania de perseguição do sr. Goliádkin, que acredita estar sempre rodeado de inimigos dispostos a prejudicá-lo. Provavelmente, a intenção de Dostoiévski tenha sido transpor para a técnica da ficção literária as novas concepções da psicologia patológica que começavam naquela época a desenvolver-se em toda a Europa. Resulta daí, portanto, a dissonância, marcada pelo embate constante entre a subconsciência e a consciência, entre a lógica e o absurdo e, consequentemente, entre a realidade e o so- 
nho, ambiguidades que caracterizam essa curiosa narrativa do início ao fim.

Como vimos, o exame da ironia exige do estudioso uma atenção redobrada, uma vez que a ironia não pode jamais ser vista como algo pontual, mas sim como uma figura de texto que deve ser analisada do ponto de vista de sua reverberação em toda a narrativa. Assim, defini-la como recurso linguístico, figura de linguagem ou ainda procedimento irônico não basta, já que a ironia é também um procedimento narrativo-discursivo, o que implica dizer que ela não se limita, isoladamente, a nenhum dos níveis linguístico, retórico ou discursivo.

É possível perceber duas tendências relacionadas à ironia, como foi visto no capítulo 2: ou a ironia se apresenta mais enquanto situação irônica e sua análise, nesse caso, envolve o enredo, as personagens e a própria estrutura da obra, ou ela se constitui por meio do refinamento de linguagem e, então, analisá-la envolve sobretudo o narrador.

Conforme foi estudado naquele capítulo, diante da "ironia observável” (ou situacional) tem-se uma situação ou uma cena que devem ser percebidas pelo observador e julgadas irônicas, não existindo, assim, "alguém sendo irônico". Já na "ironia verbal" ou "instrumental", há uma atitude irônica expressa por um sujeito, que faz uso de uma inversão semântica para transmitir sua mensagem. Logo, na ironia verbal, a linguagem é o instrumento.

Essa "divisão" da ironia em dois grandes blocos não deve, porém, ser muito rígida, afinal, quando se está nos domínios da literatura, haverá sempre o trabalho com a linguagem. Assim, embora o caso do duplo, por exemplo, incline-se mais para um tipo de ironia situacional - um personagem depara-se com uma cópia de si mesmo perambulando "por aí" -, foi necessário, para a construção dessa situação, em literatura, que a linguagem fosse tratada e manipulada para esse fim.

Portanto, seguindo o mesmo raciocínio, se o objetivo é a análise de uma obra literária, não parece ser coerente falar em "ironia sem ironista”, porque, se há trabalho com a linguagem, há ironista. 
Em suma, quando se pretende estudar a ironia na literatura, faz-se necessário perceber se ela se inclina mais para o refinamento da linguagem ou se tende mais para uma ocorrência de situação irôni$\mathrm{ca}$, devendo-se salientar sempre que, em ambos os casos, ocorre a "preparação" da linguagem. No que diz respeito à novela "O duplo" é possível encontrar a ironia nessas duas performances.

Também no capítulo 2, vimos que o traço básico de toda ironia é o contraste entre aparência e realidade, e que essa característica marca tanto a ironia verbal como a ironia observável, uma vez que, nos dois casos, se constata uma incompatibilidade ou incongruência.

Seguindo esse raciocínio, em primeiro lugar, é importante observar a seguinte contradição - ou incompatibilidade, ou incongruência - presente no texto: de um lado, o leitor é convidado a acreditar que o narrador é em certa medida conivente com as atitudes do senhor Goliádkin, mas, por outro, uma análise mais acurada revela indícios que apontam justamente no sentido contrário. Dentre esses indícios, tomemos como exemplo um momento em que o sr. Goliádkin fica enfurecido porque, ao acordar pela manhã, não encontra seu criado Pietruchka:

- Diabos o levem! - disse o senhor Goliádkin pensando no criado. - Este animal, preguiçoso como é, põe uma pessoa fora de si. Onde terá ele ido agora? Indignado - e com toda a razão - entrou no compartimento vizinho [...]. (Dostoievski, 1963, p.288, grifos nossos)

Como se percebe, o narrador parece considerar justa a indignação do senhor Goliádkin, todavia, se levarmos em conta o contexto - que nos chega pelo próprio narrador -, inferimos que a personagem principal está cometendo uma grande injustiça com Pietruchka, uma vez que este já havia organizado tudo: o coche já estava esperando; o banho, os objetos de barba e as botas que o patrão tinha pedido também já o aguardavam.

Ou seja, não havia, de fato, quaisquer motivos para aquela explosão de raiva do senhor Goliádkin, e este, mesmo tendo visto suas exigências cumpridas, trata muito mal a Pietruchka, utilizando-se, 
para qualificá-lo, de expressões grosseiras como "animal” e "idiota" o tempo todo.

Em uma outra passagem, o senhor Goliádkin encontra dois jovens que trabalham com ele na repartição e, como sempre, fica muito incomodado. Conforme descreve o narrador, "Instantaneamente e com ar receoso, encafuou-se no lugar mais escondido da carruagem" (1963, p.290). Goliádkin sente constantemente que está sendo perseguido por seus "inimigos", pois, em sua visão completamente distorcida da realidade, todos almejam humilhá-lo. Afirma, então, o narrador:

É que tinha acabado de passar por dois colegas, dois jovens funcionários da repartição em que trabalhava. Por seu lado, eles - o senhor Goliádkin bem o vira - ficaram também muito admirados em encontrar o colega em semelhante coche. Um deles havia mesmo apontado o dedo em direção ao senhor Goliádkin. (Dostoievski, 1963, p.290, grifos nossos)

Considerando as circunstâncias, pode-se concluir que o narrador, ao contrário do que sugere, não compactua com o comportamento doentio do senhor Goliádkin. Pelo contrário, critica por meio de uma refinada ironia as atitudes de sua personagem principal, conforme demonstra o seguinte trecho, sobre Goliádkin:

Abriu a boca, espreguiçou-se e, finalmente, acabou por abrir os olhos. Durante dois minutos continuou deitado sem fazer um movimento, como alguém que não sabe bem se ainda dorme ou se já está acordado, se já está rodeado do mundo real ou se continua a sonhar. (Dostoievski, 1963, p.287)

Nessa passagem, o narrador demonstra, de modo bastante claro, que o senhor Goliádkin era realmente um homem atormentado, caso contrário, como alguém, em sã consciência, poderia acordar e ficar em dúvida se está mesmo acordado? Logo, temos de concluir: primeiro, que esse homem inclina-se a distorcer toda a realidade a sua volta; segundo, que o narrador não apenas sabe disso, como in- 
clusive nos sugere a situação de sua personagem por meio dos fatos que narra, vivenciados por Goliádkin.

Portanto, no momento em que afirma, na penúltima citação, que a personagem principal "vira muito bem que estava sendo observada com admiração", o narrador é, sem dúvida, irônico.

Em outra circunstância, o senhor Goliádkin decide ir ao baile de comemoração do aniversário de Klara Olsúfievna, muito embora não tenha sido convidado para a festa. Depois de muito refletir "Entro... ou não entro? Devo entrar... ou não?... Vou... Por que não hei de ir? $\mathrm{O}$ audacioso encontra sempre maneira de atingir o que deseja..." (1963, p.308) -, o senhor Goliádkin, que já se encontrava em frente à casa de Klara, decide "participar" da festa:

Todavia, depois de ter tomado esta resolução, o senhor Goliádkin avança rapidamente, como movido por uma mola. É um instante enquanto entra na copa, tira o casaco e o chapéu, e os atira à pressa para um canto. Compõe-se um pouco e entra na sala de jantar. Daí passa para a outra sala, sem que quase ninguém dê por ele, tão entretidos estão os jogadores. Então... então... o senhor Goliádkin esquece tudo o que acaba de passar-se e, sem mais demoras, cai como uma bomba na sala de baile. (Dostoievski, 1963, p.308)

Obviamente, no momento em que as pessoas notam a presença indesejada de Goliádkin, ficam incomodadas a ponto de agruparem-se, todas, em volta dele, como se esperassem uma explicação. Goliádkin, por sua vez, fica tão aturdido que perde a capacidade de ver e de ouvir.

Passa-se algum tempo e todos, sobretudo Klara, a aniversariante, continuam dando mostras de que aquele intruso não é nem um pouco bem-vindo naquele recinto. A situação torna-se cada vez pior e o narrador, abruptamente, afirma: "É evidente que o senhor Goliádkin começa a sentir-se mais adaptado à situação” (1963, p.310).

Ora, considerando o estado agônico em que se encontra esse homem, essa asserção do narrador apenas pode ser entendida pelo 
viés da ironia. É importante perceber, ainda, que em todos os casos comentados até aqui, temos a atitude de "alguém sendo irônico", o que nos permite concluir que estamos diante de ironias verbais ou instrumentais.

Convém salientar que esse episódio - o da comemoração do aniversário de Klara - colaborou de forma assaz significativa para o colapso final de Goliádkin, pois, logo após esse acontecimento desastroso, ele encontra seu duplo e, a partir disso, sua situação psicológica e emocional piora muito.

Outros inúmeros exemplos há que apontam para uma contradição marcante entre os fatos vivenciados por Goliádkin e os comentários do narrador acerca desses mesmos fatos. Muitas vezes, são curtas observações, porém significativas, se analisadas sob o olhar da dissonância.

A seguinte passagem, em que Goliádkin se sente culpado por estar faltando ao trabalho, demonstra essa característica. Ele está, como sempre, com os pensamentos extremamente conturbados; ideias opostas lhe invadem a mente em segundos. Então, para aliviar sua consciência, cria argumentos utópicos e irreais. Comenta o narrador:

Desta maneira, o senhor Goliádkin tranquiliza sua consciência e antecipadamente justifica perante si próprio a censura que Andriéi lhe fará pela sua negligência ao serviço. Não era a primeira vez que ele encontrava razões irrefutáveis para acalmar escrúpulos da mesma natureza. Ficou assim mais uma vez com a consciência serena. (Dostoievski, 1963, p.319, grifo nosso)

Ora, de novo, levado em conta o contexto, sabemos perfeitamente que todas as afirmações e as "razões" desse homem desequilibrado psicologicamente são passíveis de contestação. Uma a uma, portanto, as passagens do texto vão deixando transparecer seu sentido irônico.

Fica demonstrado, pois, um curioso caso de dissonância no nível narrativo-discursivo. O que torna esse "evento" tão interessan- 
te é o fato de ele não ser percebido isoladamente, mas apenas dentro do contexto dessa narrativa, contemplada por uma personagem em desequilíbrio e por um narrador que sempre pauta o seu fazer narrativo pelos caminhos da ironia.

Em alguns momentos, o narrador utiliza o discurso indireto livre, o que lhe permite dissimular, agora por meio de outros recursos, sua voz no interior da narrativa. Um exemplo disso está na mesma passagem a que já nos referimos anteriormente, em que o senhor Goliádkin encontra pela rua dois rapazes com os quais trabalha na repartição:

Um deles havia mesmo apontado o dedo em direção ao senhor Goliádkin. Este se convenceu também que o outro o chamava em voz alta pelo seu nome. Ora isto em plena rua era deselegante... O senhor Goliádkin fez de conta que nada viu e não respondeu. (Dostoievski, 1963, p.290, grifos nossos)

A primeira impressão causada pelo trecho salientado ("Ora isto em plena rua era deselegante...”) é de uma manifestação solta, aparentemente de ninguém. E isso ocorre porque, graças ao uso do discurso indireto livre, não sabemos se se trata da voz do narrador ou da voz da personagem principal.

Considerando o contexto, no entanto, é possível inferir que essa afirmação só pode ser atribuída ao senhor Goliádkin, que, por vivenciar um momento de intensa perturbação psicológica, acredita veementemente estar sendo perseguido por todos os seus "inimigos".

Tanto isso é verdade que, se atentarmos melhor para a passagem acima, perceberemos que o senhor Goliádkin não ouviu ninguém gritando o seu nome, mas sim se convenceu de que o chamavam em voz alta. Quem nos diz isso é o narrador e, portanto, a afirmação de que "isto é deselegante" não pode ser sua, pois, muito provavelmente, ninguém teria chamado pelo senhor Goliádkin.

Portanto, de novo o narrador faz uso de uma estratégia para disfarçar sua "voz" no interior da narrativa. Na verdade, voz apareceu 
entre aspas porque não se trata propriamente de uma voz, mas sim de indícios da verdadeira opinião do narrador. Em outras palavras, o narrador tenta velar seu ponto de vista sobre Goliádkin não apenas apagando da narrativa as marcas que poderiam evidenciar sua opinião, mas também tencionando confundir o leitor - ora por meio da ironia, ora por meio do discurso indireto livre.

Como foi dito anteriormente, a ironia pode tender mais para uma situação irônica ou para um refinamento de linguagem. Nos casos até aqui apresentados, poderíamos concluir que a ironia se volta mais para o lado da situação irônica, uma vez que temos um narrador cuja voz é, em muitos momentos, dissonante em relação ao próprio relato - que nos chega por meio dele mesmo. Entretanto, embora exista essa incompatibilidade mostrada pelos trechos citados e, portanto, observável, não se pode desconsiderar o fato de que temos também um narrador ironizando o seu próprio relato, ou seja, uma atitude irônica.

Por conseguinte, seria um descuido optar por qualquer uma das duas classificações, excluindo a outra. Em primeiro lugar, porque, como já foi dito, estamos diante de um texto literário e, portanto, existe o trabalho com a linguagem. Em segundo lugar, porque há, com certeza, uma ironia observável entre o que o narrador narra e seus comentários; no entanto, existe também indubitavelmente a intenção narrativa de fundar uma desarmonia entre os fatos relatados e os comentários do narrador, que destoam das "verdades" contadas por ele próprio.

Logo, temos nesse texto a ambiguidade legitimada tanto pela ironia verbal ou instrumental quanto pela ironia situacional ou observável. Pode-se inclusive ir um pouco mais longe e dizer que em "O duplo" temos uma ironia observável - graças ao descompasso entre o narrado e o comentado - e, ainda, uma ironia instrumental que contribui para sinalizar a situação irônica.

Nesse sentido, voltemos ao episódio do aniversário de Klara Olsúfievna, para o qual o senhor Goliádkin não fora convidado. Nesse ponto da narrativa, a voz do narrador torna-se extremamente sarcástica, beirando, em muitos momentos, o escárnio. Se, no 
início desse episódio, o narrador apresenta com naturalidade os detalhes da comemoração, logo seu discurso começa a ser pautado por uma inconfundível mordacidade, conforme podemos notar claramente nos seguintes trechos:

Há outros bailes no mesmo gênero, mas são raros. Trata-se mais de festas de família do que de bailes. Para isso, é preciso haver uma casa como a do conselheiro de Estado Bieriendiéiev. E isso mesmo ainda não chega: julgo que nem todos os conselheiros de Estado podem dar bailes semelhantes. Se eu fosse poeta como Homero ou Puchkin - talento menor do que o deles não bastava - desejaria pintar, oh leitores! - com cores brilhantes e um hábil pincel, este dia triunfal. Seria pelo jantar que haveria de começar o meu poema. Procuraria fixar sobretudo o instante único e solene em que se ergue a primeira taça à saúde da dona da rainha da festa. Falar-vos-ia do silêncio grave dos convivas, dessa atitude de espera que se parece mais com a eloquência de Demóstenes do que com o silêncio. [...] Confesso, porém, humildemente que não seria capaz de exprimir a solenidade do instante em que a própria rainha da festa, Klara, corada como uma rosa primaveril, corada de alegria e de pudor, vencida pela emoção, cai nos braços de sua mãe e esta se põe a chorar, e o próprio pai soluça também. Simpático velho, o conselheiro de Estado. Tinha trabalhado muito. Estava paralítico das pernas, mas a sorte tinha compensado o seu esforço. Possuía uma certa fortuna, uma casa, bens de raiz. [...]

Não seria capaz de vos descrever os instantes que se seguiram. Ninguém dizia que naquela ocasião solene Andriéi Filípovitch era o chefe de repartição que todos conheciam. Parecia outra pessoa. Oh, que pena não possuir eu os segredos dum grande estilo para poder descrever estes instantes de beleza e satisfação moral. Instantes destes são a prova cabal de que muitas vezes a virtude triunfa sobre o vício e a inveja! [...]

Tudo neste instante solene parece dizer: "Eis onde o culto das virtudes pode conduzir o homem". Não vos direi que Anton Antonovitch, velho amigo da casa e padrinho de Klara, um velhinho de cabeça prateada, por sua vez, propôs também um brinde, cacarejou como um galo e recitou versos muito engraçados. Durante um momento, esqueceram-se as conveniências! Todos os presentes riram a mais não poder. A própria Klara, por sugestão dos pais, veio beijá-lo, felicitando-o pela sua boa disposição e talento. 
Os convidados, que depois de um tal jantar se sentiam todos como se fossem parentes e irmãos, acabaram por levantar-se da mesa. [...] Passaram depois a outra sala e, sem perderem um tempo que era precioso, dividiram-se em grupos (conservando a noção de sua dignidade), e foram sentar-se diante das mesas de jogos. As senhoras instalaram-se na sala e tornaram-se muitíssimo amáveis. Conversam umas com as outras sobre as coisas mais variadas e, por fim, o próprio dono da casa, que tinha perdido em serviço o uso das pernas e obtido as compensações que já dissemos, vem passear por entre os seus convidados, apoiado nas muletas [...]. Tocado pela amabilidade dos que o rodeiam, decide-se a improvisar um pequeno baile, não obstante as despesas que isso lhe acarretará. [...]

A minha pena não basta para pintar como devia o baile que a extraordinária gentileza do velho dono da casa improvisou. Como poderia eu, aliás modesto narrador das aventuras do senhor Goliádkin curiosas no seu gênero, lá isso é certo! - como poderia eu exprimir esta amálgama surpreendente de beleza, de brilho, de elegância, de alegria, de amabilidade e de júbilo; e os risos e passatempos de todas essas esposas de funcionários... Parecem mais fadas do que mulheres, com os ombros rosados, as figuras angélicas e os pezinhos encantadores a aparecerem-lhes debaixo dos vestidos. Como descrever-vos, por fim, estes funcionários transformados agora em brilhantes homens de salão, estes jovens alegres e bem constituídos, contentes e sonhadores, que, numa salinha retirada, onde as paredes são todas pintadas de verde, fumam cachimbo entre duas danças... e os cavalheiros que ocupam altos cargos e usam nomes muito sonoros, cavalheiros profundamente compenetrados de seus deveres de elegância e que, na maior parte, falam francês com as senhoras. Se falam russo é só para proferirem cumprimentos e frases profundas em tom distinto.

Unicamente na sala de fumar se permitem alguns deslizes de linguagem, frases familiares, no gênero desta "Olá, Piétienhka, dançaste esta polca como um artista." Mas - oh leitor! - tive já ocasião de dizer que a minha pena não é capaz de um tal esforço, por isso vou parar. Voltemos antes ao senhor Goliádkin, o único herói desta novela verídica. (Dostoievski, 1963, p.304-7) 
Embora o trecho seja bastante longo, optamos por reproduzi-lo visto que ele reúne diversas marcas essenciais ao estudo da ironia. Ao leitor mais ingênuo e desavisado, bem poderia parecer que o narrador objetivou, apenas, elogiar a grande festa realizada em comemoração ao aniversário de Klara.

Mesmo assim, um mínimo de atenção levaria ao estranhamento frente ao excesso de elogios conferidos a tudo: à festa, à aniversariante, às pessoas, à casa, etc. Já do ponto de vista de um leitor um pouco mais perspicaz e crítico, um outro aspecto curioso se tornaria visível: a insistente modéstia por meio da qual o narrador tece seus comentários.

Essa modéstia transparece em muitos momentos, quando ele faz asserções do tipo: "Se eu fosse poeta como Homero [...] desejaria pintar com cores brilhantes este dia triunfal" ou "Confesso, porém, humildemente, que não seria capaz..." ou ainda "A minha pena não basta para pintar como devia o baile...", entre outras.

Ora, não obstante a pena desse limitado narrador seja apresentada como insuficiente para descrever a festa, o evento é inquestionavelmente bem descrito. Dito de outra forma, o narrador considera-se incapaz de nos relatar os instantes de rara beleza compartilhados pelos convivas, todavia, pinta a ocasião com tamanha sutileza e detalhamento plástico que o leitor efetivamente "vê" o brinde realizado pelos convidados, o pai paralítico de Klara, os versos recitados (ou cacarejados?) pelo padrinho da aniversariante, as pessoas elegantes dançando, entre outras cenas.

A riqueza de detalhes e a maestria do arranjo não se coadunam, portanto, com a suposta incapacidade de que se acusou o narrador. É visível, pois, a dissonância entre a autoavaliação do narrador e as provas em contrário. Dessa vez, porém, não se trata de uma contradição na estrutura discursiva da narrativa, como a que analisamos anteriormente, ou seja, quando fatos vividos por Goliádkin (relatados pelo narrador onisciente) eram incoerentes com a opinião do narrador sobre esses mesmos acontecimentos.

Ao contrário disso, a contradição que agora verificamos (autodepreciação $\times$ excelência demonstrada) dá-se em um âmbito mais 
linguístico. Assim, entre o que o narrador diz e a mensagem que ele pretende transmitir há uma distância considerável.

Do mesmo modo, o acúmulo de elogios à festa torna patente não a aprovação inconteste, mas a crítica corrosiva àquela comemoração. $\mathrm{O}$ que poderia ser um troféu à elegância e bom gosto nada mais é do que o desnudamento da futilidade. Ao recorrer à ironia, o narrador abandona as "vias normais" para movimentar-se nas entrelinhas, onde pode dar passos mais ligeiros e maliciosos.

E esse entusiasmado narrador não para por aí: em sua opinião, as pessoas convidadas para aquela festa não são apenas fúteis, mas também hipócritas e desprovidas de qualquer escrúpulo. $\mathrm{O}$ pai de Klara não andava, mas acreditava que "a sorte tinha compensado seu esforço", pois era rico. O padrinho da aniversariante recitou versos para ela, mas a moça apenas foi agradecer-lhe por sugestão dos pais. De modo geral, as pessoas eram superficiais e nada espontâneas, porque ali, naquele recinto, segundo o narrador, estavam irreconhecíveis, ciosas apenas de seus "deveres de elegância".

O narrador, portanto, deprecia ao elogiar e desaprova por intermédio da aprovação. E, como dissemos anteriormente, sua crítica aproxima-se, algumas vezes, do escárnio: o padrinho de Klara não recita, "cacareja como um galo", seu pai, apoiado nas muletas, decide improvisar um pequeno baile... Não é preciso dizer mais nada...

Assim, terminamos aqui a análise de exemplo muito rico e sutil de ironia. Diferentemente dos primeiros casos analisados, esse último trecho é marcado por uma ironia que se manifesta exclusivamente sob a forma de um refinamento da linguagem. Isso não exclui, obviamente, que essa modalidade de ironia não tenha também um certo viés situacional - uma vez que não podemos desconsiderar o contexto em que foi produzida.

É imprescindível salientar a importância do leitor na decodificação desse texto. Conforme enfatizamos no decorrer de toda a pesquisa, o leitor se configura como elemento central dessa categoria de texto literário, já que deve localizar os aspectos que se encontram, implicitamente, em tensão.

Assim, esse tipo de discurso - ambíguo, paradoxal, contradi- 
tório e incongruente - caracterizador da narrativa analisada aqui espera do leitor a responsabilidade de tomar parte na construção do sentido. Um leitor que não se comprometa a isso, permanecendo impassível diante dos fatos narrados, jamais poderá acessar o sentido irônico, uma vez que passariam despercebidas as "notas dissonantes" espalhadas no decorrer do texto pelo narrador.

É curioso observar que, por mais atormentado que possa parecer, o senhor Goliádkin é tratado pelo narrador como herói, do início ao fim da narrativa. Assim, na última linha da citação anterior, a personagem principal é considerada "o único herói desta novela verídica". Em outras ocasiões, Goliádkin recebe as seguintes designações: "o nosso herói" (1963, p.310), "nosso desditoso herói” (1963, p.316), "este era o próprio senhor Goliádkin, não o antigo, não o herói desta novela, mas o outro Goliádkin, o novo senhor Goliádkin” (1963, p.343), "nosso herói” (1963, p.354), "nosso amigo" (1963, p.359), "nosso desgraçado herói” (1963, p.374), entre outras inúmeras ocorrências semelhantes.

Ora, que fato motivara o narrador a julgar Goliádkin um herói? Trata-se, certamente, de mais um caso de dissonância criado por esse narrador, que orienta seu relato pelos caminhos sinuosos da ironia. Além disso, é válido pensar inclusive que Dostoievski esteja ironizando o próprio gênero, o modelo de herói de uma novela, por meio da atribuição desse título a Goliádkin, um homem qualquer, sem grandes saliências.

Goliádkin é julgado maluco por todos os que o rodeiam e, inclusive, pelo leitor. Todavia, em muitos momentos, por mais curioso - e irônico - que isto possa parecer, o leitor se identifica com essa personagem. Assim como o senhor Goliádkin, também somos acometidos, vez ou outra, por um estranho sentimento de medo. Ditos populares como "Está muito bom para ser verdade" confirmam a presença de maus pressentimentos inseridos no ser humano - pressentimentos estes que nos aproximam, em certa medida, do senhor Goliádkin. A seguinte passagem revela o desequilíbrio dessa personagem no sentido de acreditar que, sempre, algo acontecerá como não devia, ocasionando prejuízos e danos: 
Seria bem desagradável - disse baixinho para si próprio - seria bem desagradável se hoje qualquer coisa corresse mal, se me aparecesse, por exemplo, um furúnculo ou qualquer outra coisa aborrecida. Felizmente, por enquanto tudo está correndo bem, muito bem até... (Dostoievski, 1963, p.287)

No decorrer de nossa existência, também procuramos - e encontramos - assim como o senhor Goliádkin, razões "irrefutáveis" que justifiquem nossas falhas mais graves e, como se não bastasse, também, muitas vezes, projetamos esses erros no Outro e o consideramos inimigo. De forma parecida, o ser humano fica, muitas vezes, inseguro em relação à sua profissão e tem receio de que "tomem o seu lugar", como aconteceu com Goliádkin na repartição onde trabalhava.

E, provavelmente, nossa maior semelhança com essa destemperada personagem seja o reconhecimento do Estranho em nós mesmos. Muitas vezes, por razões diversas, ocorre a eclosão daquilo que tão insistentemente recalcamos, ou seja, aquilo que nos é esquisito e que gostaríamos de esconder retorna, quebra a moldura e escapa a nosso controle.

Seria possível continuar citando outras inúmeras questões análogas entre nós, leitores, e o disparatado senhor Goliádkin; entretanto, não é o que interessa aqui. Importa, sim, dizer que o narrador conferiu, ironicamente, a esse indivíduo desnorteado a designação de herói e que provavelmente seja mais irônico ainda o fato de que este "desditoso herói" não seja simplesmente um tresloucado, mas apenas humano.

O erro de Goliádkin talvez tenha sido salientar demais o Outro em si mesmo, a ponto de concretizá-lo, conferindo-lhe vida. Isto também não deixa de ser estranhamente dissonante: tendências desconhecidas incrustadas no interior do próprio indivíduo...

Esperamos que tenha ficado claro que essa narrativa é fundamentada na problemática da ironia. Assim, seja ela fruto de um primoroso trabalho com a linguagem, ou esteja ela mais próxima de uma situação irônica propriamente dita, falamos constantemente de ironia. 
É possível inferir que o narrador de "O duplo" tenha se servido da ironia de forma tão intensa, como se observou, a fim de alterar o horizonte de expectativas do leitor. Desse modo, já que se constitui essa novela como um elogio à contradição, o leitor é convidado pelo narrador, a todo momento, a pensar ou concluir algo diferente do que concluíra antes.

Por conseguinte, se, num primeiro instante, o leitor acredita que o narrador é conivente com as atitudes do senhor Goliádkin, percebemos, após uma leitura mais pormenorizada, que ele critica o comportamento dessa personagem nas entrelinhas. Porém, se por um lado existem os julgamentos do narrador, em contrapartida, há também uma voz que revela ao leitor sua semelhança com as esquisitices do desnorteado Goliádkin.

Sem dúvida alguma, estamos à frente de um texto polifônico que, como tal, expõe o leitor a várias possibilidades de leitura. Em "O duplo" não nos deparamos, pois, com um narrador cuja característica seja impor ao leitor seu ponto de vista em relação aos fatos narrados. Muito pelo contrário, esse narrador deixa para o leitor a tarefa de julgar.

Não pretendemos dizer que ele (o narrador) se abstém dessa "responsabilidade": aquele por meio do qual a história nos chega em "O duplo" avalia sim, tece julgamentos muitas vezes sagazes sobre os acontecimentos relatados. Suas apreciações, porém, nunca encerram a análise dos fatos. Isso se dá porque, em primeiro lugar, tais apreciações, como vimos, são irônicas e, nesse sentido, já apontam para duas possibilidades de interpretação e, em segundo lugar, porque tais julgamentos são, muitas vezes, contraditórios, ampliando, assim, as possibilidades de leitura.

Dessa maneira, se, por um lado, o narrador critica sutilmente sua personagem, por outro, se compadece explicitamente do senhor Goliádkin, dando a entender ao leitor que está do lado dessa personagem e que entende muito bem a dor sentida por aquele homem. As seguintes passagens ilustram o que se está a dizer aqui: 
Sentia-se o pior possível. Dentro de si tudo era um caos. Andou muito tempo de um lado para o outro, perturbadíssimo. Depois, já sentado, pousou a cabeça nas mãos e, esforçando-se por refletir, procurou uma saída para a situação em que se encontrava. (Dostoievski, 1963, p.304)

[...] depois, de repente, dá um salto como se estivesse louco, e põe-se a correr, a correr, sem se voltar, parece fugir diante de um inimigo, diante do infortúnio... pois a sua situação é terrível. (Dostoievski, 1963, p.313)

Empurrada pelo vento, a água caía em jorros quase horizontais, tal como sai das mangueiras dos bombeiros. Batia e chicoteava o rosto do infeliz senhor Goliádkin, como se fossem agulhas e alfinetes aos milhares. (Dostoievski, 1963, p.312)

Deparamo-nos, portanto, com um texto que se caracteriza principalmente por reunir vozes dissonantes. Nisso reside, pois, a perspicácia desse narrador sobre quem tanto falamos: colocar nas mãos do leitor a tarefa de absolver ou condenar Goliádkin. E, ao final dessa instigante leitura, embora reconheçamos as graves falhas cometidas por esse homem, sentimos pena ao "vê-lo" se afastar rumo ao manicômio, dentro daquele coche.

A ironia atua nessa narrativa, portanto, justamente para instalar a desarmonia, a discrepância entre dois discursos. Temos em "O duplo", como vimos, uma voz que condena o senhor Goliádkin, mas também percebemos a presença de um "grito" - talvez mais abafado - que se apieda desse homem, e se apieda porque se sente próximo a ele. Logo, nesse texto como em outros, a ironia contribui indubitavelmente para a derrocada do maniqueísmo, na medida em que, por meio da ambiguidade, nega nossas certezas sobre o senhor Goliádkin, sobre nós mesmos...

Apesar de tantos disparates cometidos por Goliádkin - e, na verdade, por causa exatamente desses disparates -, achamo-nos ironicamente semelhantes a esse herói idiotizado de ideias estranhas e obsessivas, a esse homem cujos pensamentos são compul- 
sivos e indomáveis, a esse homem tão "estranhamente" distante do equilíbrio, a esse homem... humano.

\section{O homem duplicado, de José Saramago: a dissonância aparente}

Essa narrativa peculiar conta a história de Tertuliano Máximo Afonso, um professor de História que, em uma noite tumultuada, depara-se com alguém cujas características são absolutamente idênticas às suas. Sua cópia fiel aparece em um filme a que Tertuliano assistia: era um ator secundário. O título do filme era Quem porfia mata a caça.

Essa constatação incomoda muito Tertuliano, que decide, no decorrer da narrativa, marcar um encontro com o ator, cujo nome é Antonio Claro. Eles se encontram e, devido a uma reviravolta, acabam invertendo os papéis: Tertuliano veste as roupas de Antonio Claro e este se traveste de Tertuliano.

Um acidente de carro acontece e Antonio Claro acaba sendo vítima fatal. Entretanto, como estava com as vestimentas de Tertuliano, para todos os efeitos, quem morrera foi o professor de História. Tertuliano - para não ser considerado louco - assume, pois, a vida do ator, incluindo sua esposa - a única pessoa que sabe dos duplos.

Em O homem duplicado, de José Saramago, existe aparentemente um discurso legitimador da polifonia, que defende, pois, a liberdade de opinião e a existência de vozes portadoras de diferentes verdades inseridas no relato. Contudo, é interessante perceber que, enquanto esse discurso polifônico existe nas camadas mais superficiais do texto, existe uma outra voz - esta menos explícita, situada nos "subterrâneos" do texto - que justamente satiriza a possibilidade de polifonia discursiva.

É no embate entre essas duas vozes - opostas apenas aparentemente - que sobressai o caráter irônico dessa "mensagem" transmitida pelo narrador, que, na verdade, faz uso de estratégias diversas a fim de manipular o leitor.

Entre os dispositivos utilizados pelo narrador está a ironia ro- 
mântica. Logo, é precisamente nos momentos em que a narrativa - entendida como sequência dos fatos narrados - para que o narrador aproveita para intrometer-se, tecendo comentários variados. Tais intromissões são caracterizadas ora por discussões metalinguísticas, ora por trazerem à baila assuntos que se encontram fora do espaço ficcional, ora, ainda, para persuadir o leitor a aceitar um determinado ponto de vista. Em todos esses casos, está presente a ironia romântica. Convém, portanto, examinar esses momentos de intervenção do narrador para apreender suas intenções e também para conhecer os procedimentos de construção de sentido utilizados pela instância narrativa.

Assim, observemos o fragmento abaixo, onde o narrador propõe questionamentos que apontam para o interior da narrativa, realizando uma reflexão sobre o próprio fazer literário por meio do recurso à ironia romântica:

desde que se divorciou Máximo Afonso, servimo-nos aqui da versão abreviada do nome porque à nossa vista a autorizou aquele que é seu único senhor e dono, mas principalmente porque a palavra Tertuliano, estando tão próxima, apenas duas linhas atrás, viria desservir gravemente a fluência da narrativa. (Saramago, 2002, p.12)

Temos, nele, a discussão explícita do fazer literário, que aponta, ao que parece num primeiro momento, para dois caminhos opostos: a ficção e a realidade. O narrador parece explicar sua decisão de não reproduzir o nome inteiro da personagem apoiando-se, primeiramente, na ficção, uma vez que afirma ter o próprio Tertuliano permitido que ele (o narrador) assim procedesse. Depois, no entanto, a instância narrativa se vale de um argumento relacionado ao ato literário em si mesmo - ao trabalho com as palavras - e, nesse momento, não faz, aparentemente, uso do ficcional, mas sim da realidade referente ao ato de escrever.

Logo, nessa passagem, o narrador parte do ficcional, dando a entender, contudo, que está nos domínios da realidade, quando, de fato, trata-se sempre de uma estratégia de reforço do ficcional. Esse 
jogo entre ficção e "realidade" se faz presente em toda a narrativa. Leiamos outro fragmento:

Um parêntesis indispensável. Há alturas da narração, e esta, como já se vai ver, foi justamente uma delas, em que qualquer manifestação paralela de ideias e de sentimentos por parte do narrador à margem do que estivessem a sentir ou a pensar nesse momento as personagens deveria ser expressamente proibida pelas leis do bem escrever. A infração, por imprudência ou ausência de respeito humano, a tais cláusulas limitativas, que, a existirem, seriam provavelmente de acatamento não obrigatório, pode levar a que a personagem, em lugar de seguir uma linha autônoma de pensamentos e emoções coerente com o estatuto que lhe foi conferido, como é seu direito inalienável, se veja assaltada de modo arbitrário por expressões mentais ou psíquicas que, vindas de quem vem, é certo que nunca lhe seriam de todo alheias, mas que num instante dado podem revelar-se no mínimo inoportunas, e em algum caso desastrosas. Foi precisamente o que sucedeu a Tertuliano Máximo Afonso. Olhava-se ao espelho como quem se olha ao espelho apenas para avaliar os estragos de uma noite mal dormida, nisso pensava e em nada mais, quando, de súbito, a desafortunada reflexão do narrador sobre os seus traços físicos e a problemática eventualidade de que em um dia futuro, auxiliados pela demonstração de talento suficiente, poderiam ser postos ao serviço da arte teatral ou da arte cinematográfica, desencadeou nele uma reação que não será exagero classificar de terrível. (Saramago, 2002, p.34-5, grifos nossos)

Em primeiro lugar, há a presença de uma ironia corrosiva no momento em que o narrador afirma que "os traços físicos de Tertuliano, aliados à demonstração de talento suficiente, levariam essa personagem, no futuro, ao trabalho com a arte teatral ou com a arte cinematográfica".

$\mathrm{Na}$ verdade, o leitor ainda não sabe, nessa altura da narrativa, que é justamente isso o que ocorrerá com Tertuliano Máximo Afonso. Nas últimas páginas do romance, graças a uma fatalidade, ele toma o lugar do ator Antonio Claro. Como foi dito no início dessa análise, os duplos trocam de papéis, devido, sobretudo, à im- 
becilidade de Tertuliano, que, chantageado por Antonio, seu duplo, insiste em não contar nada sobre os duplos a Maria da Paz.

O resultado da teimosia de Tertuliano e da ira de Antonio Claro, que, sentindo-se perseguido, decide agora também perseguir, é o seguinte: o ator quer que Tertuliano conte tudo a Maria da Paz e o professor de História se nega até as últimas consequências, permitindo que Antonio Claro vista as suas roupas e vá, em seu lugar, encontrar Maria. Vestido como Tertuliano, o ator dirige-se até Maria da Paz, enquanto Tertuliano decide ir encontrar-se com Helena, a esposa do ator.

Por "ironia do destino", Antonio Claro e a namorada de Tertuliano sofrem um acidente de carro e morrem. Porém, para todos os efeitos, quem morrera fora Tertuliano. E este acaba, portanto, assumindo a vida do ator.

Logo, o que fez com que o professor de História se transformasse, no futuro, em ator, foi uma sequência de erros, ocasionados pela incapacidade de Tertuliano de se relacionar francamente com as pessoas. Afinal de contas, ele permitiu que o ator fosse, em seu lugar, ao encontro de Maria da Paz apenas para não contar a ela, sua "companheira", toda a verdade.

Em outras palavras, não foi por uma "demonstração de talento suficiente" que Tertuliano se transformou em ator, como o narrador ironicamente afirma na passagem analisada. Ao contrário disso, a passagem de Tertuliano de professor de História a ator de cinema se deve à sua incompetência e inabilidade.

Como se vê, o leitor deve participar ativamente da construção do sentido e isso vale - e muito - para essa obra de Saramago. Objetivamos fazer entender, por meio da passagem acima, que o papel do leitor é fundamental, uma vez que, apenas no final do romance, pode compreender o sentido irônico desse fragmento. Fica legitimada também - além da importância do leitor, que deve "decifrar" as pistas jogadas por esse narrador no decorrer do texto - a importância do contexto. Na verdade, falar do contexto é já apontar para o leitor, na medida em que é justamente ele quem deve estar atento para perceber e apreender esse contexto. 
Além disso, é interessante notar que ocorre no trecho anterior o reforço do ficcional, uma vez que na passagem "a problemática eventualidade de que em um dia futuro [...] poderiam ser postos ao serviço da arte teatral" fica patente que não se trata de uma "eventualidade". O narrador sabe o que ocorrerá com Tertuliano no futuro: isso já fora calculado, sendo, pois, ficção.

Se, de um lado, o narrador parece conferir "vida" à sua personagem no momento em que afirma que Tertuliano se incomoda com os pensamentos do narrador, que são inseridos em sua mente, de outro, a instância narrativa também parece sugerir exatamente o contrário: um "ser de papel", um "fantoche" (no caso, Tertuliano) completamente manipulado pelo narrador, que, olhado dessa maneira, detém todo o relato.

Parece haver no trecho anterior, portanto, uma intenção do narrador de legitimar o ficcional, afirmando que seus personagens não têm vida e tampouco autonomia, e que se contentam em receber os pensamentos que o narrador lhes impõe. A seguinte passagem é também bastante expressiva quanto a esses pontos que estamos analisando:

Para o relator, ou narrador, na mais do que provável hipótese de se preferir uma figura beneficiada com o sinete da aprovação acadêmica, o mais fácil, chegado a este ponto, seria escrever que o percurso do professor de História através da cidade, e até entrar em casa, não teve história. Como uma máquina manipuladora do tempo, mormente no caso de o escrúpulo profissional não ter permitido a invenção de uma zaragata de rua ou de um acidente de trânsito com a única finalidade de encher os vazios da intriga, aquelas três palavras, Não Teve História, empregam-se quando há urgência em passar ao episódio seguinte ou quando, por exemplo, não se sabe muito bem que fazer com os pensamentos que a personagem está a ter por sua própria conta, sobretudo se não têm qualquer relação com as circunstâncias vivenciais em cujo quadro supostamente se determina e atua. Ora, nesta exata situação se encontrava o professor e novel amador de vídeos Tertuliano Máximo Afonso enquanto ia guiando o seu carro. É verdade que pensava, e muito, e com intensidade, mas os pensamentos dele eram a tal extremo 
alheios ao que nas últimas vinte e quatro horas tinha andado a viver, que se resolvêssemos tomá-los em consideração e os trasladássemos a este relato, a história que nos havíamos proposto contar teria de ser inevitavelmente substituída por outra. É certo que poderia valer a pena, melhor ainda, uma vez que conhecemos tudo sobre os pensamentos de Tertuliano Máximo Afonso, sabemos que valeria a pena, mas isso representaria aceitar como baldados e nulos os duros esforços até agora cometidos, estas quarenta compactas e trabalhosas páginas já vencidas, e voltar ao princípio, à irônica e insolente primeira folha, desaproveitando todo um honesto trabalho realizado para assumir os riscos de uma aventura, não só nova e diferente, mas também altamente perigosa, que, não temos dúvidas, a tanto os pensamentos de Tertuliano Máximo Afonso nos arrastariam. Fiquemos portanto com este pássaro na mão em vez da decepção de ver dois a voar. Além disso, não há tempo para mais. (Saramago, 2002, p.52-3, grifos nossos)

Ao contrário do que vimos nesse trecho, agora o narrador afirma que pululam pensamentos na mente de Tertuliano Máximo Afonso e que, no entanto, o melhor mesmo é desconsiderá-los, uma vez que tais pensamentos desvirtuariam o percurso narrativo. Logo, se, por um lado, mais uma vez, o narrador insinua ser seu personagem principal "autônomo", por outro, deixa claro que irá ignorar as reflexões de Tertuliano, confirmando seu "autoritarismo" na condução do relato.

Apenas aparentemente o narrador finge concordar com a ideia de que seus personagens possam se conduzir sozinhos, expressando juízos que não sejam arbitrários ou que não reproduzam unilateralmente os pensamentos do autor. Ao contrário disso, na verdade, Saramago parece satirizar os estudos literários que defendem a possibilidade e a manutenção de discursos polifônicos. Isso fica muito claro quando o narrador afirma que "o escrúpulo profissional" não teria permitido a invenção de uma zaragata de rua, e ainda quando diz que ele até poderia aceitar reproduzir os pensamentos de Tertuliano, mas isso desviaria muito o rumo da história, anulando o seu "serviço".

Percebemos que tais considerações do narrador só podem ser 
consideradas pelo viés da ironia. É possível inclusive pensarmos numa espécie de paródia dos discursos polifônicos quando o narrador afirma que o "escrúpulo profissional" não permite que ele invente nada, ou quando diz, ironicamente, que nós "sabemos que valeria a pena" ouvir a "voz" de Tertuliano, muito embora saibamos que, na verdade, esse personagem é uma criatura extremamente desinteressante...

Como se percebe, valendo-se de diversas estratégias, o narrador cria um jogo entre a realidade e a ficção. No início da passagem citada, ele afirma que "o percurso do professor de História através da cidade, e até entrar em casa, não teve história”, e que isso é um fato. Aventa a possibilidade de poder inventar algo como "um acidente de trânsito com a única finalidade de encher os vazios da intriga", o que se contrapõe a seu suposto "escrúpulo profissional" que o impediria de tal interferência.

Dessa forma, a instância narrativa parece instigar o leitor a acreditar que esse narrador nada inventa, relatando apenas aquilo que verdadeiramente aconteceu. Todavia, se de fato o narrador nada tem a criar - porque seu "escrúpulo profissional" não consente nisso -, dispondo-se somente a transpor fatos para o papel, como um mero "relator", por que haveria de negar-se a reproduzir os "reais" pensamentos de Tertuliano? Essa negação em si já desmente esse narrador, uma vez que revela seu pleno controle da narrativa.

Ora, seria impossível chegar a um sentido satisfatório para o trecho analisado se não o examinarmos, mais uma vez, pelo viés da ironia. Ocorre que o narrador afirma que nada inventa e que seus personagens têm pensamentos próprios, contudo, como vimos, ele se desmente. Mas é óbvio que estamos diante de uma estratégia: o narrador não faz mais do que mostrar, ironicamente, que comanda o fazer literário, reforçando, pois, o ficcional e manipulando o leitor segundo lhe apraz.

Todas essas considerações apontam para a constatação de que o narrador reconhece o quão penoso é o trabalho literário, caso contrário, não titubearia em listar os pensamentos "de Tertuliano", abandonando o fio narrativo, segundo ele, arduamente construído. 
A expressão "de Tertuliano" foi colocada entre aspas justamente para que se perceba que, na opinião desse narrador, não existem realmente pensamentos que possam ser atribuídos aos personagens: eles não têm autonomia, estão sob o domínio de um narrador manipulador.

Logo, se estamos falando em "trabalho literário", isso já exclui qualquer "registro mecânico" de fatos para o papel, conforme propõe ironicamente o narrador. É também de forma irônica que a instância narrativa tenta propagar a opinião de que nada "inventa" - consideração esta que não deixa de contribuir com a verossimilhança. Na verdade, portanto, ocorre nesse trecho uma ênfase aos caminhos escarpados do fazer literário.

Essa tensão entre vozes aparentemente adversas e irônicas é, sem dúvida alguma, proposital. Está inserida no trecho analisado, como em outros do romance, a fim de provocar no leitor uma interessante reflexão sobre o ato criativo literário. Por conseguinte, o narrador parece nos propor, de maneira instigante, uma meditação sobre a criação literária e, mais pontualmente, sobre a origem do fazer literário: seria a fantasia ou a realidade o "terreno fértil" de onde brotaria a literatura?

As três passagens abaixo expressarão de maneira assaz reveladora a tensão a que nos referimos até aqui. Todas se referem a Tertuliano:

Se do próprio responsável da idéia não podemos, neste momento, esperar que nos ilumine os caminhos, sem nenhuma dúvida tortuosos, por onde vagamente estará imaginando que alcançará os seus objetivos, não se conte conosco, simples transcritores de pensamentos alheios e fiéis copistas das suas ações, para que antecipemos os passos seguintes de uma procissão que ainda agora vai no adro. (Saramago, 2002, p.188, grifos nossos)

No entanto, o privilégio de que gozamos, este de saber tudo quanto haverá de suceder até à última página deste relato, com exceção do que ainda vai ser preciso inventar no futuro [...]. (2002, p.244, grifos nossos) 
Tal como parece que da natureza se diz, também a narrativa tem horror ao vazio, por isso, não tendo Tertuliano Máximo Afonso, neste intervalo, feito alguma coisa que valesse a pena relatar, não tivemos outro remédio que improvisar um chumaço de recheio que mais ou menos acomodasse o tempo à situação. Agora que ele se resolveu a tirar a cassete da caixa e a introduziu no leitor, poderemos descansar. (2002, p.88, grifos nossos)

Nesses trechos, mais uma vez, o leitor precisa de atenção redobrada para não os interpretar literalmente. Se assim procedemos, somos obrigados a constatar uma simples oposição, ou um jogo do narrador, que ora conduz o leitor para a esfera do ficcional, ora para a esfera do "real", ao discutir sobre as adversidades do fazer literário. Tal postura reduziria muito a análise.

Esses trechos exigem que lancemos sobre eles um olhar irônico, pois este foi com certeza o olhar do narrador. Quando ele se diz "simples transcritor de pensamentos alheios e fiel copista de suas ações”, novamente é lícito entendermos que estamos perante uma sátira ao discurso que defende a ideia de que uma narrativa deve se conduzir por si mesma, sem a manipulação do narrador. Portanto, a independência das personagens e a isenção do narrador são apenas aparentes. $\mathrm{O}$ narrador desse romance manipula, cria, utiliza-se de estratégias de convencimento e enfatiza ironicamente o caráter ficcional da narrativa.

É interessante chamar a atenção para o fato de que esse narrador sempre sugere, insinua, aventa possibilidades sem comprometer-se com nenhum afirmação explícita. Conforme temos insistido, cabe ao leitor aceitar - ou não - o convite bastante sutil desse narrador para que ele (o leitor) decifre esse texto caracterizado por tantas mensagens sub-reptícias.

O receptor dessa obra de Saramago deve, pois, estar atento para perceber as pistas deixadas pelo narrador e, concomitantemente, participar da construção do sentido. A própria instância narrativa, por meio de uma interessante digressão, chama a atenção do leitor para a importância de se decifrar os discursos subliminares, nomeados por ele de "subgestos": 
aproveitemos para desenvolver um pouco, pouquíssimo para o que a complexidade da matéria necessitaria, a questão dos subgestos, que aqui, pelo menos tanto quanto é do nosso conhecimento, pela primeira vez se levanta. É costume dizer-se, por exemplo, que Fulano, Beltrano ou Sicrano, numa determinada situação, fizeram um gesto disso, ou daquilo, ou daqueloutro, dizemo-lo assim, simplesmente, como se o isto, ou o aquilo, ou o aqueloutro, dúvida, manifestação de apoio ou aviso de cautela, fossem expressões forjadas de uma só peça, a dúvida, sempre metódica, o apoio, sempre incondicional, o aviso, sempre desinteressado, quando a verdade inteira, se realmente a quisermos conhecer, se não nos contentarmos com as letras gordas da comunicação, reclama que estejamos atentos à cintilação múltipla dos subgestos que vão atrás do gesto como a poeira cósmica vai atrás da cauda do cometa, porque esses subgestos, para recorrermos a uma comparação ao alcance de todas as idades e compreensões, são como as letrinhas pequenas do contrato, que dão trabalho a decifrar, mas estão lá. (Saramago, 2002, p.46-7, grifos nossos)

Fica evidente aqui que o narrador faz realmente um convite ao leitor para que este dê importância às palavras ditas de maneira indireta, pois elas correspondem, de acordo com ele, à "verdade inteira". A instância narrativa refere-se, conforme é possível inferir, à própria narrativa que edifica, caracterizada, portanto, pela sugestão, pela insinuação ou ainda pelos "subgestos".

Além disso, o romance ainda apresenta casos diferentes de ironia romântica, passagens realmente significativas por proporcionarem uma reflexão que, de fato, extrapola os limites do ficcional. Examinemos o seguinte fragmento:

É de todos conhecido, porém, que a enorme carga de tradição, hábitos e costumes que ocupa a maior parte do nosso cérebro lastra sem piedade as idéia mais brilhantes e inovadoras de que a parte restante ainda é capaz, e se é verdade que em alguns casos essa carga consegue equilibrar desgovernos e desmandos de imaginação que Deus sabe aonde nos levariam se fossem deixados à solta, também não é menos verdade que ela tem, com frequência, artes de submeter sutilmente a 
tropismos inconscientes o que críamos ser a nossa liberdade de atuar, como uma planta que não sabe por que terá sempre de inclinar-se para o lado de onde lhe vem a luz. (Saramago, 2002, p.86)

Como se vê, a instância narrativa tece um comentário bastante crítico que abrange muito mais do que apenas Tertuliano Máximo Afonso e sua dificuldade em administrar bem sua vida em todos os setores (amoroso, profissional, pessoal)... Na verdade, por meio dessa intervenção - assim chamada porque interrompe o fio narrativo -, o narrador desenvolve reflexões que apontam para fora da história, aqui entendida como série de fatos narrados.

Tais reflexões dirigem-se, portanto, ao próprio ser humano e à sua irracional tendência a pôr de lado todo seu "brilhantismo" e seus planos reais de vida em nome das convenções sociais e da "enorme carga de tradição", como afirma esse narrador no trecho acima. Valendo-se dessa instância narrativa, Saramago nos convida a pensar um pouco sobre nosso direito à liberdade. É curioso notar que, mais uma vez, o convite não se faz às claras: é sugerido.

Ao contrário dos trechos de ironia romântica examinados anteriormente, que contribuíam com o reforço do ficcional, essa passagem, embora parta do ficcional (da vida sem sentido de Tertuliano), joga o leitor abruptamente para fora da narrativa, impelindo-o a refletir sobre sua vida "real" e sobre sua própria condição no mundo. Afinal, o narrador parece perguntar ao leitor a qual das duas esferas ele pertence: a daqueles submetidos completamente aos hábitos e tradições sociais, responsáveis por nos cercear, ou à categoria daqueles que, libertos, veem com mais facilidade as tentativas de manipulação que os rodeiam.

Vejamos outras duas passagens:

Afinal estará a dormir quando a mulher entrar na sala, mas o efeito não se perdeu por completo, ela julgou que ele se tinha levantado para estudar o papel, há algumas pessoas assim, gente a quem um apurado sentido da responsabilidade mantém permanentemente inquietas, como se em cada momento estivessem a faltar a um dever e disso se acusassem. (Saramago, 2002, p.233, grifos nossos) 
A alma humana é uma caixa donde sempre pode saltar um palhaço a fazer caretas e a deitar-nos a língua de fora, mas há ocasiões em que esse mesmo palhaço se limita a olhar-nos por cima da borda da caixa, e se vê que, por acidente, estamos procedendo segundo o que é justo e honesto, acena aprovadoramente com a cabeça e desaparece a pensar que ainda não somos um caso perdido. (Saramago, 2002, p.293)

Em ambos os fragmentos temos um narrador que toma a ficção como ponto de partida para a sua análise do Homem, atraindo, depois, o leitor consigo para fora do ficcional, para sua realidade, para sua existência como ser humano no mundo. A reflexão acerca da vida, acerca do "estar no mundo" e seus entraves inicia-se, pois, na ficção e se completa na "realidade", quando o leitor consegue aplicar tais raciocínios a seu cotidiano, avaliando as necessidades de mudança - ou não.

É fundamental salientar ainda a sensibilidade desse narrador, que se faz presente no decorrer de toda a narrativa. Trata-se de passagens dignas de um poeta, tendência também patente na passagem a seguir, na qual o escritor se utiliza com maestria de uma linguagem toda figurada para nos falar do homem e do professor limitado e sem vitalidade que é Tertuliano Máximo Afonso:

A História que Tertuliano Máximo Afonso tem a missão de ensinar é como um bonsai a que de vez em quando se aparam as raízes para que não cresça, uma miniatura infantil da gigantesca árvore dos lugares e do tempo, e de quanto neles vai sucedendo, olhamos, vemos a desigualdade de tamanho e por aí nos deixamos ficar, passamos por alto outras diferenças não menos notáveis, por exemplo, nenhuma ave, nenhum pássaro, nem sequer o diminuto beija-flor, conseguiria fazer ninho nos ramos de um bonsai [...]. (Saramago, 2002, p.15)

Encontramos aqui, mais uma vez, o diálogo entre a ficção e a realidade presente em $O$ homem duplicado, de José Saramago. Como foi visto, por meio de estratégias discursivas diferentes, a intenção subjacente a esse texto é constante: evocar a discussão sobre a arte literária e suas funções. 
Assim, seja através do recurso à ironia romântica que reforça o ficcional, seja por meio da ironia romântica que nos envia para fora do texto ficcional, as mesmas indagações são sempre recorrentes: quais são os limites da literatura? Quais são suas origens e seus motivos? De onde ela vem e para onde vai?

Nós, leitores, somos constantemente orientados por esse narrador a não buscar respostas pontuais para esses questionamentos. $\mathrm{Na}$ verdade, embora o narrador enfatize o ficcional, ironicamente, nas primeiras passagens analisadas, baseados nos últimos excertos observados, podemos afirmar que, para Saramago, o fazer literário não é só "ficção" ou apenas "realidade", não se inicia com a fantasia e termina com a verdade e nem só parte da verdade e caminha para a ficção.

Observemos o seguinte trecho do romance:

A vida real sempre nos tem parecido mais parca em coincidências que o romance e as outras ficções, salvo se admitíssemos que o princípio da coincidência é o verdadeiro e único regedor do mundo, e nesse caso tanto deveria valer aquilo que se vive como aquilo que se escreve, e vice-versa. (Saramago, 2002, p.170-1)

Essa passagem é extremamente significativa, na medida em que elucida justamente a discussão realizada até o momento. Ora, o narrador tece o seguinte raciocínio: a "vida real" é pobre em coincidências em relação à ficção; entretanto, "o princípio da coincidência é o verdadeiro e único regedor do mundo”. A instância narrativa insinua, mais uma vez, pois, a necessidade de amalgamar realidade e ficção, colocando essas duas "categorias" no mesmo patamar, conferindo a elas, por conseguinte, a mesma importância. "Ouçamos" as palavras do estudioso Antonio Candido:

A fantasia quase nunca é pura. Ela se refere constantemente a alguma realidade: fenômeno natural, paisagem, sentimento, fato, desejo de explicação, costumes, problemas humanos, etc. Eis por que surge a in- 
dagação sobre o vínculo entre fantasia e realidade, que pode servir de entrada para pensar na função da literatura. (Saramago, 2000, p.130)

Logo, o fazer literário é "feito" de realidade e de ficção, sempre. Como explica Antonio Candido, a literatura parte muitas vezes do real, transpondo "marcas de realidade" para a ficção que se edifica. Porém, tais marcas serão apreendidas - ou não - pelo leitor, que as conduzirá novamente para sua realidade.

Portanto, uma vez que parte do real, a literatura carrega consigo certa dose de "verdade" e é justamente por isso que tem também o papel tão importante de possibilitar a transformação do ser humano e, consequentemente, de seu mundo. Trata-se, por conseguinte, de um maravilhoso e infinito processo; "maravilhoso" e "infinito" porque instaura, perpetuamente, a possibilidade de mudança.

Convém que nos perguntemos, finalmente, sobre a escolha das profissões de Tertuliano Máximo Afonso e de Antonio Claro. Quais razões determinam que o primeiro seja um professor de História e o segundo, um ator? O historiador lida com fatos reais que já sucederam, enquanto o ator trabalha em geral com a ficção, ou seja, com fatos que poderiam ter acontecido.

Tertuliano Máximo Afonso, em sua condição de professor de História - aliás, um mau professor na opinião do narrador -, consegue enxergar apenas o palpável, o real. Ele não tem nenhum conhecimento sobre o outro e parece não se importar com isso. Falta-lhe, pois, autoconhecimento, uma vez que o exercício da alteridade não lhe é costumeiro.

Dito de outra maneira, Tertuliano não valoriza o convívio com as outras pessoas. $\mathrm{O}$ professor de História não sente simpatia e muito menos amizade por ninguém em seu ambiente profissional. A única pessoa com quem mantém um relacionamento é Maria da Paz, a quem ele constantemente magoa, porque não a reconhece enquanto companheira:

Tertuliano Máximo Afonso marcou o número do telefone de Maria da Paz, provavelmente atende-lo-ia a mãe, e o breve diálogo seria 
mais uma pequena comédia de fingimentos, grotesca e com um ligeiro toque de patético, A Maria da Paz está, perguntaria, Quem quer falar com ela, Um amigo, Como é o seu nome, Diga-lhe que é um amigo, ela saberá de quem se trata [...] Ao longo de seis meses de sua relação com Maria da Paz não foram muitas as vezes que Tertuliano precisou de telefonar-lhe [...]. (Saramago, 2002, p.122)

Tertuliano não entende, pois, nada do ser humano e muito menos de si, vivendo centrado em si mesmo e, por isso, não conseguindo resolver seus conflitos interiores.

Antonio Claro, em contrapartida, é ator. Sua profissão é, de certa forma, oposta à de Tertuliano, uma vez que o êxito de seu trabalho está justamente em se colocar "na pele" dos outros, vivenciando experiências diferentes. Antonio Claro é um fingidor; precisa imitar a dor e os prazeres alheios e, para ser convincente, necessita se aproximar e entender o outro.

Bem, José Saramago, ao que parece, está tentando dizer algo por meio de toda essa representação. Em primeiro lugar, é preciso reconhecer uma refinada ironia na finalização dessa narrativa: o professor de História é, na verdade, quem morre, uma vez que terá que esquecer sua própria vida e encarnar a figura do ator. Assim, o ator morreu e, entretanto, continuará vivo na pele de Tertuliano Máximo Afonso. Trata-se de uma profunda ironia: o professor de História está vivo, mas, na "realidade", morreu, e o ator, por sua vez, morreu, mas, "de fato”, está vivo.

Seguindo esse raciocínio, é possível imaginar que a personagem do ator é uma metáfora da própria obra literária. Tertuliano, o professor de História, parece estar destinado a encontrar o ator, seu duplo. Tudo leva a Antonio Claro, e Tertuliano não consegue mais evitar o encontro, pois sente necessidade dele. Nicole Fernandez Bravo (2000, p.273), referindo-se a um personagem de Hoffmann, que vive um conflito muito parecido com o de Tertuliano, afirma: "Somente pela aceitação final de sua identidade na solidão e na religião (substitutas da arte, que, noutros textos, é o meio de trans- 
cender a existência humana fadada ao dilaceramento) é que ele assumirá sua identidade”.

O contato com a arte literária - representada pelo ator - permitirá que Tertuliano inicie uma viagem para dentro de si mesmo, rumo ao autoconhecimento. É curioso perceber que Tertuliano não apenas "entrou em contato" com o ator, mas inclusive tomou seu lugar.

Isso significa que é justamente por meio da aproximação e da identificação com o texto ou com personagens literários - ou com a arte de maneira geral - que se conhece a si mesmo. Agora, na pele do ator, o professor de História será obrigado a praticar o exercício da alteridade e, gradualmente, tornar-se-á uma pessoa melhor. Ocorre, portanto, a morte simbólica do professor de História a fim de que um outro, mais humano e mais sensível, chegue a nascer.

Saramago realizou com maestria uma metaficção, já que utilizou uma obra de arte literária para refletir justamente sobre a importância fundamental da arte na construção da identidade. $O$ homem duplicado é, sem dúvida, uma narrativa que contempla um interessante processo de autorreflexão, uma vez que tematiza o próprio processo da escrita literária.

Logo, Saramago entende que a literatura atua na formação do homem. Para tanto, dá ênfase à profunda relação que existe entre o real e o ficcional. Antonio Candido, em seu texto "A literatura e a formação do homem”, afirma que o laço entre a imaginação literária e a realidade concreta do mundo é o que caracteriza a literatura como uma "força" integradora e transformadora do ser humano.

$\mathrm{O}$ autor de $\mathrm{O}$ homem duplicado representou de maneira incisiva a importância da arte literária: colocou um historiador (representante do real, do concreto) em uma busca obsessiva pelo ator, seu duplo (representante da ficção). O contato entre esses dois grandes personagens permitirá - ou não (porque muitos e muito diferentes são os Tertulianos...) - o início da busca de si mesmo.

Como fecho da presente análise vale lembrar que "A metaficção revela sua condição de artifício e explora a problemática relação en- 
tre vida e ficção. Simultaneamente se cria uma ficção e é constatada a invenção da mesma" (Waugh, 1990, p.34).

\section{As refrações da ironia em O cavaleiro inexistente, de Calvino}

Consideramos $O$ cavaleiro inexistente, de Ítalo Calvino, uma obra fundamental para nossa investigação, uma vez que, além de contemplar a problemática da ironia, paródia e riso, convida o leitor a participar ativamente da construção do sentido. E isso se dá desde o fato de que a história - entendida como sequência de fatos narrados - não parece ser a primeira preocupação do narrador. $\mathrm{Na}$ verdade, a essência do texto está não na superfície exposta, mas nas suas lacunas, nas entrelinhas, ou seja, naquele espaço que parece extrapolar a narrativa propriamente dita. Essa essência precisa ser destilada do texto, chegando-nos, assim, de modo indireto. Uma vez vislumbrada, ela revela uma substância envolvida pela complexa trama da ironia, do riso e da paródia.

Como paródia das novelas de cavalaria medievais, a obra está estruturada por uma série de oposições. A primeira delas é justamente a contradição entre os cavaleiros de Carlos Magno e Agilulfo Emo Bertrandino dos Guildiverni e dos Altri de Corbentraz e Sura, cavaleiro de Selimpia Citeriori e Fez, ou simplesmente o "cavaleiro inexistente".

É interessante notar que a própria figura de Carlos Magno - poderoso imperador franco que brilha com destaque na história europeia, estando na raiz de França, Alemanha e Itália - é igualmente parte da trama irônica e risível construída pelo narrador. Paródia do herói medieval e da própria concepção de monarquia, Carlos Magno nos é mostrado em meio a seus cavaleiros e em oposição ao cavaleiro Agilulfo, compondo um quadro que justamente mostra seu lado menos fotogênico. Assim, já na primeira página da narrativa, lemos o seguinte: 
Finalmente, vislumbraram-no avançando lá no fundo, Carlos Magno, num cavalo que parecia maior que o natural, com a barba no peito, as mãos no arção da sela. Reina e guerreia, guerreia e reina, faz e desfaz, parecia um tanto envelhecido, desde a última vez que aqueles guerreiros o tinham visto. (Calvino, 2005, p.7, grifos nossos)

Percebemos, sobretudo pelos trechos salientados, o objetivo do narrador de desmistificar as imagens de "belo" e "eterno" associadas a Carlos Magno. Na verdade, seu cavalo "parecia maior que o natural”, ou seja, já temos aí sutilmente criticada a questão da aparência de grandeza e virtude, empregada também em relação ao cavalo. Quando o narrador afirma que Carlos Magno "parecia um tanto envelhecido”, demonstra sua intenção, também implícita, de "humanizar" a figura de Carlos Magno, despindo-a das auréolas de "belo", "eterno", "grandioso" e outras de mesmo quilate.

O narrador satiriza, ainda, o automatismo do rei, que se comporta como um robô, entrevistando os cavaleiros:

e seguia adiante: - E-quem-é-você, paladino da França? - repetia, sempre com a mesma cadência: "Tata-tatatai-tata-tata-tatata..." [...] Todas coisas que, ditas pelo rei, dão prazer, mas eram sempre as mesmas frases, há tantos anos. (Calvino, 2005, p.8)

O fato de ser Agilulfo um cavaleiro que não existe - mas que pode ser visto - não parece incomodar o rei, que o entrevista sem dar grande importância a isso. O narrador não deixa que esse ponto passe despercebido: "[o rei] girou o cavalo e afastou-se rumo ao acampamento real. Já velho, tendia a eliminar da mente as questões complicadas" (2005, p.10).

No que diz respeito aos cavaleiros, a instância narrativa age de mesma maneira:

Todo o resto, a perpétua confusão do exército em guerra, o formigueiro diurno no qual o imprevisto pode se manifestar como a fúria de um cavalo, agora silencia, pois o sono venceu a todos: guerreiros e quadrúpedes da cristandade, estes enfileirados e em pé, às vezes esfregan- 
do um casco no chão ou emitindo um breve relincho ou zurrando, aqueles finalmente livres dos elmos e das couraças, satisfeitos por se tornarem seres humanos distintos e inconfundiveis, ali estão todos roncando em uníssono. [...] Em nenhum lugar se dorme tão bem como no exército. (Calvino, 2005, p.12, grifos nossos)

Aqui, os comentários tecidos pelo narrador acerca dos cavaleiros e dos animais são, propositalmente, confusos. Homens e cavalos são nivelados, pois "roncam em uníssono". Porém, o narrador, irônico, afirma que os cavaleiros estão "satisfeitos por se tornarem seres humanos distintos e inconfundíveis". Inconfundíveis? Ora, a ironia do narrador não poderia ser mais pungente. É interessante perceber, ainda, que a designação "quadrúpedes da cristandade" é carregada de malícia e, em contrapartida à desumanização ou desindividualização dos homens, confere traços humanos aos animais.

Em muitas outras passagens, os cavaleiros são correlacionados aos animais por meio das descrições do narrador: "e entre corcovear e dar cotoveladas, seus escudos prateados erguiam-se e abaixavam-se como guelras de um peixe. O exército se parecia com um peixe comprido repleto de escamas: uma enguia" (2005, p.23) Em vários momentos, o narrador flagra os cavaleiros se alimentando e, então, nos deparamos com cenas frequentemente dantescas:

Os pratos são os habituais no exército: peru recheado, pato no espeto, carne de vaca na brasa, leitão, enguias, dourado. Os valetes mal chegam a depositar as bandejas e os paladinos se atiram em cima, pegam com as mãos, despedaçam com os dentes, engorduram as couraças, espirram molho por todos os lados. Há mais confusão que no combate: sopeiras que são viradas, frangos assados que voam, e os valetes que levam as bandejas antes que um insaciável as esvazie em sua tigela. (Calvino, 2005, p.62-3)

Como se vê, existe realmente uma intenção do narrador de ridicularizar esses cavaleiros e isso inclui a figura de Carlos Magno. O trecho que acabamos de citar descreve um "banquete dos paladi- 
nos" e, durante esse jantar, ocorre uma revelação importante sobre Agilulfo: a castidade da dama salva por ele é questionável. Ora, foi justamente por ter defendido a pureza de uma pobre virgem que Agilulfo tinha se tornado cavaleiro do rei, de modo que seu posto poderia ser colocado em xeque. Toda essa discussão acontece durante páginas entre os cavaleiros e não ouvimos a voz do rei. Por fim, o narrador apenas acrescenta: "Carlos Magno, que até então mantivera rosto e barba inclinados sobre um prato de camarões de rio, julgou que chegara a hora de levantar o olhar" (2005, p.67). Assim, a crítica aos cavaleiros não poupa o rei Carlos Magno.

Já as descrições de Agilulfo têm caráter bem distinto. Vejamos a primeira delas:

Agilulfo deu alguns passos para misturar-se a um daqueles abrigos, depois sem motivo foi para outro, mas não se ambientou e ninguém ligou para ele. Permaneceu um pouco indeciso às costas de um e de outro, sem participar dos diálogos, depois colocou-se à parte. [...] A armadura branca despontava isolada em meio ao prado. [...] Agilulfo era certamente um modelo de soldado; porém, antipático a todos. (Calvino, 2005, p.10-1)

Por ser extremamente correto, esse personagem era odiado por todos os demais cavaleiros. Seu perfeccionismo não lhe permitia aceitar qualquer negligência no serviço dos colegas: "chamava-os um por um, retirando-os das doces conversas ociosas da noitada, e contestava com discrição e firme exatidão as faltas deles [...]” (2005, p.11).

Portanto, Agilulfo se opõe a esses cavaleiros, sobretudo em relação à sua conduta: enquanto os cavaleiros são fúteis, irracionais e ociosos, o cavaleiro inexistente é trabalhador, responsável e, acima de tudo, ainda que não exista, Agilulfo pensa. Observemos a seguinte passagem:

Em nenhum lugar se dorme tão bem como no exército. Somente Agilulfo não conseguia esse alívio. $\mathrm{Na}$ armadura branca, completamente equipada, no interior de sua tenda, uma das mais ordenadas e 
confortáveis do acampamento cristão, tentava manter-se deitado e continuava pensando: não os pensamentos ociosos e divagantes de quem está para pegar no sono, mas sempre raciocínios determinados e exatos. [...] Como era possível aquele fechar de olhos, aquela perda de consciência de si próprio, aquele afundar num vazio das próprias horas e depois, ao despertar, descobrir-se igual a antes, juntando os fios da própria vida, Agilulfo não conseguia saber, e sua inveja da faculdade de dormir característica das pessoas existentes era uma inveja vaga, como de algo que não se pode nem mesmo conceber. (Calvino, 2005, p.12-3, grifos nossos)

Agilulfo nutre, pois, sensações ambíguas em relação aos "homens que existem”. Sente raiva de seus erros e nojo de seus hábitos - por exemplo, roncar e babar enquanto dormem -, no entanto, inveja sua capacidade de fechar os olhos e se desligar da vida por algumas horas.

Um personagem que contribui muito com a caracterização que estamos apresentando dos cavaleiros e de Agilulfo é Rambaldo de Rossiglione, um aspirante a cavaleiro. Seu único desejo é vingar a morte de seu pai, morto como herói na guerra, pelas mãos do pagão emir Isoarre. Rambaldo é ingênuo, pois vê na guerra um meio de justiça e enxerga os cavaleiros como personificações da honra. No entanto, à medida que convive com a cavalaria de Carlos Magno, decepciona-se:

Rambaldo gostaria de ter se misturado com aquela multidão que pouco a pouco tomava a forma de pelotões e companhias incorporadas, mas tinha a impressão de que aquele bater de ferros era como um vibrar de élitros de insetos, um crepitar de invólucros secos. Muitos dos guerreiros estavam fechados no elmo e na couraça até a cintura, e sob os flancos e os protetores dos rins despontavam as pernas com calças e meias porque deixavam para colocar coxotes, perneiras e joelheiras quando já estivessem montados. As pernas, sob aquele tórax de aço, pareciam mais finas, como patas de grilo; e a maneira como se moviam, falando, as cabeças redondas e sem olhos, e também o modo de manter dobrados os braços pesados de cubitais e manoplas parecia coisa de grilo ou de formiga; $e$ 
assim toda aquela azáfama lembrava um zumbido indistinto de insetos. No meio deles, os olhos de Rambaldo procuravam algo: era a armadura branca de Agilulfo que ele esperava reencontrar, talvez porque sua aparição teria tornado mais concreto o resto do exército, ou então porque a presença mais sólida com que ele se deparara havia sido justamente a do cavaleiro inexistente. (Calvino, 2005, p.19-20, grifos nossos)

Como se vê, Rambaldo, que desejava ser sagrado cavaleiro e que acabara de chegar ao exército, espera encontrar um cavaleiro idealizado: grandioso, forte, honesto e justo. Ao se deparar com a cavalaria de Carlos Magno, entretanto, experimenta uma frustração não apenas quanto ao caráter dos cavaleiros, mas também ao porte físico daqueles homens, cujas pernas eram finas "como patas de grilo". A magreza e fragilidade dos cavaleiros eram disfarçadas pela armadura... Ironicamente, Rambaldo busca Agilulfo, o cavaleiro inexistente, "porque sua aparição teria tornado mais concreto o resto do exército."

Logo, é possível inferir que, de fato, existe uma oposição bastante significativa entre Agilulfo e o exército do imperador Carlos Magno. Não há dúvida de que se trata de um contraste irônico, uma vez que o cavaleiro em questão não existe e, mesmo assim, ele é justamente a "presença mais sólida" entre os "paladinos da França”. Num outro momento, o narrador ainda afirma: "Rambaldo gostaria de trocar confidências com o cavaleiro da armadura branca, como se fosse o único capaz de compreendê-lo, nem ele mesmo saberia dizer por quê" (Calvino, 2005, p.43).

Certamente, estamos diante da contradição irônica que sustenta a paródia criada por Ítalo Calvino. Como dissemos, a obra em questão pode ser lida como uma paródia das novelas de cavalaria medievais. Nesse sentido, temos, pois, Agilulfo, de um lado, representando o cavaleiro ideal, bondoso, casto, honrado e cristão. De outro, os cavaleiros tais como eles são: irracionais, preguiçosos, desajeitados, feios e maliciosos. Esse contraste é irônico, pois não nos chega diretamente: o leitor é convidado a colaborar na edificação desse texto, fazendo a ponte entre a referência antiga (História) e a 
realização nova (obra do século XX); entre a retomada de um ideal (que enobrece a figura abstraída do passado) e a mesquinhez do cotidiano humano (que afeta a todos - ontem e hoje); entre arte e observação da realidade. A crítica e ironia de Calvino recai, assim, igualmente sobre Carlos Magno e seus cavaleiros.

Ao mesmo tempo que rebaixa o imperador e sua cavalaria, a narrativa põe em cena a figura de Agilulfo, um modelo de cavaleiro, o representante do "cavaleiro medieval" - que, não obstante, é um "cavaleiro inexistente". Sua falta de materialidade aponta para seu caráter tanto ideal quanto ficcional.

Em seu artigo "O cavaleiro inexistente e o homem sem sombra - ou de quando não se vê a imagem no espelho”, publicado na revista Mirabilia, Maria da Penha Casado Alves entende que

Ítalo Calvino com seu romance $O$ cavaleiro inexistente polemiza com toda a tradição dos romances de cavalaria e dialogicamente ri de todo esse universo idealizado, apresentando-nos a decadência, senilidade e finitude dos personagens magníficos que povoavam os romances de cavalaria medievais, particularmente de Carlos Magno e seus paladinos. (2003)

Segundo esse ponto de vista, estamos diante de um texto que parodia justamente a visão do cavaleiro medieval como "herói imaculado". Na verdade, a história nos atesta que o cavaleiro que participava das Cruzadas não estava absolutamente interessado em "levar a fé aos povos bárbaros", mas sim em pôr em prática quaisquer expedientes a fim de alcançar benefícios, como o lucro, a conquista de poder e status social. Não é sem razão que o historiador Leo Hubermann (1986, p.18) chama as Cruzadas de "expedições de saque". Massaud Moisés, ao comentar A demanda do Santo Graal, traz à baila questões que são também pertinentes para O cavaleiro inexistente:

A Demanda corresponde precisamente à reação da Igreja Católica contra o desvirtuamento da Cavalaria. Os cavaleiros andantes feudais 
não raro acabaram por se transformar em indivíduos desocupados, quando não em autênticos bandoleiros, vivendo ao sabor do acaso, amedrontando, pilhando, assaltando. A fim de trazê-los à civilização, reconvertendo-os aos bons costumes, o Concílio de Clermont, em 1095, decidiu a organização da primeira Cruzada e a correspondente formação de uma cavalaria cristã. Inicia-se uma vasta pregação de ideais de altruísmo e respeito às instituições. A Demanda, cristianizando a lenda pagã do Santo Graal, colabora intimamente com o processo restaurador da Cavalaria andante: caracteriza-se por ser uma novela mística, em que se contém uma especial noção de herói antifeudal, qualificado por seu estoicismo inquebrantável e sua total ânsia de perfeição. Novela a serviço do movimento renovador do espírito cavaleiresco, em que o herói também está a serviço, não mais do senhor feudal, mas de sua salvação sobrenatural, uma brisa de teologismo varre-a de ponta a ponta, o que não impede, porém, a existência de circunstâncias jactos líricos e eróticos, nem algumas gotas de fantástico ou mágico, em que o real e o imaginário se cruzam de modo surpreendente. (1999, p.29)

Agilulfo representa certamente esse cavaleiro paradigmático buscado pela Igreja para melhorar a imagem dos cavaleiros, que tinham fama de bandoleiros e saqueadores. Logo, em $O$ cavaleiro inexistente, encontramos, de um lado, Agilulfo, representando o ideal de perfeição e, de outro, Carlos Magno e seu exército corporificando a nua e crua realidade acerca dos cavaleiros.

Um personagem que colabora muito para a legitimação dessa crítica à cavalaria é Torrismundo, um dos cavaleiros de Carlos Magno. Ele é o causador do conflito vivido por Agilulfo, pois declara que Sofrônia - justamente a moça que teve sua castidade salva por Agilulfo - é sua mãe (de Torrismundo). Ora, se Sofrônia já era mãe de Torrismundo, Agilulfo não preservou sua virgindade e, desse modo, não deveria fazer jus ao título que lhe fora conferido, à época desse acontecimento, de "cavaleiro de Carlos Magno". Agilulfo corre, então, o mundo em busca de Sofrônia a fim de provar sua castidade.

Ao final, ficamos sabendo que tudo não passara de um engano, 
uma vez que Torrismundo e Sofrônia não tinham, na verdade, nenhum parentesco de sangue. Sofrônia ainda era imaculada quando foi encontrada por Torrismundo, e vivia a sua primeira experiência amorosa. Ambos são surpreendidos após a consumação do ato sexual e, antes que tudo fosse explicado, Agilulfo some com seu cavalo, acreditando que os dois eram mesmo mãe e filho e que, portanto, ele não salvara a honra de Sofrônia no passado. Apenas a armadura de Agilulfo é encontrada, vazia; dele, não se teve mais notícias.

Ao montar esse enredo, no mínimo confuso, o narrador parece fazer uma crítica às convenções: primeiro porque, se Sofrônia não fosse virgem, não mereceria ser protegida por Agilulfo; segundo, porque Agilulfo só poderia ser considerado um "cavaleiro nobre e ímpio" se tivesse salvado uma dama casta, caso contrário, deveria perder o posto de cavaleiro. A vida de Sofrônia e as qualidades de Agilulfo se constituem, realmente, como preocupações secundárias.

Como dissemos, enquanto Agilulfo sai em busca de Sofrônia, Torrismundo, acreditando ainda ser filho dela, antes que todo esse mistério fosse desvendado, passa a procurar por seu pai, que, segundo ele, é a "Sagrada Ordem dos Cavaleiros do Santo Graal"! Nesse ponto, o tom crítico da narrativa atinge seu auge. Vejamos o momento em que Torrismundo explica as circunstâncias de sua concepção ao rei Carlos Magno e aos cavaleiros:

- Meu pai não é um homem.

- E quem seria? Belzebu?

- Não, sire - disse calmamente Torrismundo.

- Quem então?

Torrismundo avançou até o meio da sala, pôs um joelho no chão, ergueu os olhos para o céu e disse:

- É a Sagrada Ordem dos Cavaleiros do Santo Graal. Um murmúrio percorreu o banquete. Alguns dos paladinos se benzeram.

- Minha mãe era uma menina ousada - explicou Torrismundo e corria sempre para o mais profundo dos bosques que circundavam o castelo. Certo dia, no fundo da floresta, deparou-se com os cavaleiros do Santo Graal, lá acampados para fortificar seu espírito no isolamento do mundo. A menina começou a brincar com aqueles guerreiros e a 
partir daquele dia, sempre que possível, enganava a vigilância familiar e alcançava o acampamento. Mas em pouco tempo, com aquelas brincadeiras de criança, acabou grávida. (Calvino, 2005, p.70)

Carlos Magno, sem grande susto, afirma:

Se você conseguir chegar até os cavaleiros do Santo Graal e fazer-se reconhecer como filho de toda a ordem, considerada coletivamente, seus direitos militares, dadas as prerrogativas da ordem, não seriam diferentes daqueles que tinha como filho de uma família nobre. (Calvino, 2005, p.70)

A ironia que percorre esses trechos é muito interessante, conduzindo-nos, sem dúvida alguma, ao riso. O leitor que participa da construção do sentido percebe que fatos, no mínimo hediondos, são narrados com uma impressionante naturalidade. Antes de tudo, Sofrônia é tratada por "menina" porque tinha apenas treze anos, quando se acreditava que ela teria engravidado. Então, o narrador, por meio de uma ironia sutil, afirma que Sofrônia, graças àquelas "brincadeiras de criança" com os guerreiros da "santa ordem", acabou grávida.

E pior: não se podia atribuir a paternidade a um único guerreiro. Torrismundo explica: "- Minha mãe nunca me falou de um cavaleiro em particular, mas me educou para respeitar como pai a sagrada ordem em seu conjunto" (2005, p.70). Bem, ao que tudo indica, Sofrônia, aos treze anos, manteve relações sexuais com todos os cavaleiros da "Sagrada Ordem dos Cavaleiros do Santo Graal", de modo que acabou grávida e, nada mais "natural" do que afirmar que todos eles, considerados coletivamente, são "os pais" de Torrismundo!

Rimos da incongruência entre a gravidade desse acontecimento e a aparente e calculada "espontaneidade" por meio da qual esse fato é narrado. Depois de algumas páginas, o leitor fica sabendo que não foi nada disso: Sofrônia ainda era intocada até encontrar-se com Torrismundo, que não era seu filho... Mas que diferença faz? 
Isso não torna a "Sagrada Ordem" menos culpada, uma vez que o que interessa à instância narrativa é justamente insinuar a possibilidade de tamanho delito.

Essa possibilidade se faz legítima graças à tranquilidade por meio da qual é narrada e, ainda, pela aceitação pacífica de Carlos Magno. Portanto, para Ítalo Calvino, o que importa não parece ser, de fato, a "história em si mesma", até porque ela é muito confusa e, não raro, completamente inverossímil. Esse autor se interessa, sim, em criticar, refletir, propor, insinuar ideias e pensamentos de modo irônico; tais "propostas de reflexão" se encontram, pois, sob essa trama confusa. A história se configura como um mero pretexto, portanto.

Como já dissemos, Torrismundo vai ao encontro dos cavaleiros do Graal e se surpreende com o que encontra:

Outros cavaleiros seguravam tochas acesas e ateavam fogo nos tetos, nos depósitos de feno, nas estrebarias, nos celeiros miseráveis, até que as aldeias ficassem reduzidas a fogueiras que eram só gritos e prantos. Torrismundo, arrastado pela corrida dos cavaleiros, estava transtornado. - Alguém me diga por quê? - gritava para o ancião, indo atrás dele, como se fosse o único que podia ouvi-lo. - Então não é verdade que estejam cheios de amor pelo todo! Ei! Atenção, estão atacando aquela velha! Como têm coragem de investir sobre restos humanos? Socorro, as chamas atingem aquele berço! Mas o que estão fazendo? Não queira interferir nos desígnios do Graal, noviço! - advertiu o ancião. - Não somos nós quem faz isso; é o Graal, que está em nós, que nos move! Entregue-se ao seu amor furioso! (Calvino, 2005, p.102)

Portanto, não há dúvida de que estamos diante de um texto paródico. Calvino demole um a um os ideais associados aos cavaleiros medievais. Tais homens são criminosos, porque saqueiam, porque roubam, porque investem contra as mulheres e as crianças e porque matam. Essas atitudes são ironicamente criticadas por Ítalo Calvino. Falta a esses cavaleiros nobreza de caráter e respeito pelos semelhantes e, pelo viés da ironia, da paródia e do riso, o autor de $O$ cavaleiro inexistente denuncia essa índole perversa. 
Conforme dissemos, o cavaleiro Agilulfo está no lado oposto: é íntegro, responsável, racional, trabalhador, entretanto não existe, não passa de uma armadura impecável e vazia. Talvez esteja aqui a maior ironia da obra, pois que o ideal - representado por Agilulfo - não existe. Sua existência como ideal torna-o algo que não se concretizou nunca e não se pode concretizar jamais.

Logo, Ítalo Calvino parece ter encontrado a estratégia mais eficaz e mais brilhante para expressar a sua mensagem: personificou o paradigma do cavaleiro nobre e perfeito em um personagem que não existe, edificando pelos caminhos da ironia e da paródia uma verdadeira obra de arte. Pois é, assim como Galahaad também só poderia existir em uma obra literária, ficcional. Afinal, ele concretiza um ideal de retidão, abstinência e devoção que nenhum ser humano de carne e osso conseguiria igualar.

O riso tem também um lugar especial nessa narrativa. Entendido como resultado de uma incongruência entre a razão e a realidade concreta, ele percorre, como não podia deixar de ser, todas as páginas de $O$ cavaleiro inexistente. A própria condição do cavaleiro Agilulfo, que existe sem existir é risível. Como vimos na parte teórica deste livro, estamos falando de um riso que nos convida a refletir: afinal, se rimos da situação de "existência" de Agilulfo, surpreendemo-nos ainda mais quando nos aproximamos dos possíveis motivos pelos quais Ítalo Calvino cria esse personagem, constituído dessa maneira.

Afora toda a organização estrutural da narrativa - que é, sem dúvida, irônica - e que cria consequentemente a oportunidade para o evento do riso, há um personagem que colabora muito para a irrupção do risível: Gurdulu, um andarilho encontrado pelo exército de Carlos Magno. Ele tem uma especificidade, que é a de transformar-se, sem o perceber, nas pessoas, nos objetos ou ainda nos animais com que se depara. Tal como a inexistência de Agilulfo, tal fato não é verossímil. Mas a verdade é que Gurdulu em vários momentos tem o papel fundamental de servir à estratégia ficcional de criar a ironia segundo os parâmetros de Schopenhauer 
e reforçar a postura crítica. Vejamos, antes de mais nada, alguns momentos em que aparece Gurdulu:

Em meio às aves, havia um homem, mas não dava para entender o que fazia: andava de cócoras, com as mãos atrás das costas, levantando os pés de pato como um palmípede, com o pescoço duro e dizendo: "Quá... quá... quá...". Os patos não ligavam para ele, como se o reconhecessem enquanto um deles. [...] Os paladinos acercaram-se do pântano. Não se via Gurdulu. Os patos, atravessado o espelho d'água, haviam retomado o caminho entre o capim com seus passos palmípedes. Ao redor da água, do meio das avencas, subia um coro de rãs. $O$ homem tirou a cabeça da água de repente, como se lembrasse que devia respirar naquele momento. Viu-se perdido, como se não entendesse o que era aquele contorno de avencas dentro d'água a um palmo de seu nariz. Em cada folha, sentava-se um animalzinho verde, liso liso, que o examinava e coaxava com toda a força: "Gra! Gra! Gra!". Gra! Gra! Gra! - respondeu Gurdulu, contente e, ao som de sua voz, de todas as avencas, era um tal de rã pular na água, e, da água, rãs saltando para a margem, e Gurdulu gritando: - Gra! - deu um pulo ele também, foi para a margem, ensopado e enlameado da cabeça aos pés, encolheu-se feito uma rã e lançou um "Gra!" tão forte que com um barulho de caniços e capins tornou a cair no pântano. (Calvino, 2005, p.24-5)

Num outro momento, o exército se depara mais uma vez com a figura de Gurdulu:

A cavalgada ladeava um pomar de pereiras. Os frutos estavam maduros. Com as lanças os guerreiros espetavam peras, fazendo-as desaparecer no bico dos elmos, depois cuspiam o que sobrava. Enfileirado entre as pereiras, quem se vê? Gurdulu. Mantinha os braços para cima, torcidos feito ramos, e nas mãos, na boca, na cabeça e nos rasgões da roupa carregava peras.

- Olhem, ele está bancando uma pereira! - exclamava Carlos Magno, risonho.

- Já vou sacudi-lo! - disse Orlando, e deu-lhe uma pancada.

Gurdulu deixou cair ao mesmo tempo todas as peras, que rolaram 
pelo prado em declive, e ao vê-las descer não pôde fazer outra coisa senão rolar também ele feito pera no relvado e assim desapareceu da vista de todos. (Calvino, 2005, p.26)

Em vários momentos da narrativa, temos a oportunidade de ver Gurdulu confundindo-se com as coisas a seu redor e são, realmente, cenas muito engraçadas. Não se trata, porém, do "riso sério" fruto de uma contradição, estudado no capítulo 4, mas sim de um riso que é fruto da constatação de um erro ou defeito no outro. $\mathrm{O}$ riso que nos interessa mais, o riso de Schopenhauer, acontece na cena seguinte, que narra o encontro entre Gurdulu e o rei Carlos Magno:

Dois paladinos iam na frente arrastando Gurdulu com todo o seu peso como se fosse um saco. Aos empurrões, colocaram-no em pé diante de Carlos Magno.

- Tire o chapéu, sua besta! Não vê que está diante do rei??

O rosto de Gurdulu iluminou-se, era uma carantonha encalorada em que se misturavam caracteres francos e mourescos [...] Começou a desfazer-se em reverências e a falar sem parar. Aqueles nobres senhores, que até então só haviam escutado de sua boca vozes de animais, ficaram espantados. [...] Entre palavras ininteligíveis e despropósitos, seu discurso era mais ou menos este:

- Toco o nariz com a terra, caio em pé nos vossos joelhos, declaro-me augusto servidor de Vossa Humilíssima Majestade, comandem-se e me obedecerei! - Brandiu uma colher que trazia presa na cintura. - ...E quando a Majestade Vossa diz: "Ordeno, comando e quero", e faz assim com o cetro, assim com o cetro como eu faço, estão vendo?, e grita como eu: "Ordenooo, comandooo e querooo!", vocês, todos súditos cães, têm de me obedecer senão mando empalar todos e, em primeiro lugar, você aí com essa barba e cara de velho decrépito!

- Devo cortar-lhe a cabeça de um golpe só, sire? - perguntou Orlando, e já desembainhava.

- Rogo graça para ele, Majestade - apressou-se o hortelão. - Foi um de seus descuidos habituais: falando com o rei, confundiu-se e não se lembrou mais se o rei era ele ou aquele com quem falava. (Calvino, 2005, p.27-8) 
Como se vê, todos os momentos anteriores de confusão de Gurdulu que foram narrados parecem preparar o terreno para esse encontro e, consequentemente, para o instante, já antecipado pelo leitor, em que Gurdulu se confundisse com o rei Carlos Magno. Se observarmos bem a cena, percebemos que a confusão não se dá imediatamente: só aos poucos Gurdulu vai assimilando a figura de Carlos Magno e revelando, também gradualmente, a tirania e a estupidez do rei.

É interessante perceber, ainda, que, antes de a "confusão" completar-se, quando Gurdulu ainda tem a noção exata de quem era ele e de quem era o rei, já aí a crítica a Carlos Magno se faz presente. A recusa ao rei apenas se intensifica à proporção que a transposição ocorre, e chega ao cúmulo quando Gurdulu se dirige ao rei como "um velho decrépito". Portanto, não resta dúvida de que a figura de Gurdulu serve como um expediente interessante de que o narrador faz uso para, ironicamente, atacar o despotismo de Carlos Magno.

Obviamente, rimos, e esse riso é consequência de uma incongruência: em primeiro lugar, o leitor não espera essa atitude tão "lúcida" de Gurdulu, julgado um louco. Depois, o leitor se dá conta da ironia: entre as confusões anteriores de Gurdulu e essa última - a confusão com Carlos Magno - há uma grande distância. Se, nos momentos anteriores, consideramos Gurdulu simplesmente um insano, agora entendemos que sua percepção é, de certo modo, crítica e inteligente. Por meio de Gurdulu, a instância narrativa tece, portanto, uma crítica muito pertinente ao rei Carlos Magno. Aquele que ri dessa última "peripécia" de Gurdulu, compreende a tensão, assimila o contraste, empresta seu saber para a construção do sentido e, desse modo, alarga seu conhecimento.

O cavaleiro inexistente é, como se vê, uma obra muito complexa e multifacetada, de modo que jamais poderíamos encerrar a análise de todos os seus aspectos. Só a figura do narrador, por exemplo, daria um rico trabalho, uma vez que é apenas ao final da história que o leitor percebe que a história é narrada por Bradamante, uma mulher que integra o exército de Carlos Magno, sendo desejada por 
todos os cavaleiros, mas que está disposta a relacionar-se apenas com Agilulfo. Bradamante é apaixonada pelo cavaleiro inexistente e seu papel de narradora certamente mereceria ser investigado em outro trabalho.

O que nos interessa por ora, entretanto, é justamente legitimar a estrutura dissonante da narrativa, marcada de modo significativo pela ironia, que acaba propiciando também a presença da paródia e do riso. Conforme pudemos observar, para Ítalo Calvino não importa muito a lógica racional ou a realidade concreta, mas sim o convite - endereçado ao leitor - para olhar o mundo de um modo diferente e, quem sabe, assim, entendê-lo um pouco melhor. Em contato com personagens - de certo modo, tão absurdos como Agilulfo e Gurdulu -, o leitor é chamado a libertar-se de uma visão padronizada e racional e enxergar algo além das ideias preconcebidas. Para tanto, deve transcender a mímesis ingênua e por vezes bastante inverossímil e desvelar as mensagens sub-reptícias e irônicas. 



\section{CONSIDERAÇÕES FINAIS}

A ironia, o riso e a paródia podem ser descritos como discursos tentadores. Lançam no texto sua estrutura ambivalente e aguardam com ansiedade que o sujeito se dê conta de seu traço dual. Essas modalidades sinalizam, acenam, provocam obstinadamente todo aquele que se aventura a encará-las frente a frente em sua complexidade. Desafiam sutilmente a razão do sujeito que agora, em face desses artifícios minuciosamente arranjados, está fadado a desnudar a incongruência inesperada. Ou não. Essas categorias são assimétricas, privilegiam a sugestão, o silêncio, o não dito.

Por se caracterizarem desse modo peculiar, o riso, a paródia e a ironia despertam em seus receptores sensações adversas. Os que desvelam a sua cilada experimentam o céu, deleitam-se, acham-se mais capazes intelectualmente: provocados, sentem que corresponderam ao desafio. Em contrapartida, uma sensação de embaraço nos invade sempre que, chamados, não estivemos atentos ao convite dessa espécie de textos, seja por distração, seja por não compartilhar um determinado repertório. Na verdade, sabemos que não deveria ser assim; no entanto, também estamos cientes de nossas vaidades...

Reiteramos no decorrer de toda a investigação que o sujeito é o elemento central dos textos que contemplam a ironia, a paródia e 
o riso. Somente ele pode fazer acontecer esses discursos. O receptor dessas modalidades de estudo deve comportar-se como alguém que investiga um caso muito intrigante, repleto de provas controversas, desafios e propostas tentadoras. Ele - o sujeito - deverá sinalizar, com base nos "fatos" do texto, a "verdade" e a manipulação.

Nesse sentido, o sujeito experimenta a sensação desconfortável de se localizar no limiar entre o implícito e o explícito, entre o sub-reptício e o literal, entre os subterrâneos e a superfície do texto. Constitui-se como tarefa do receptor dessas estruturas ambíguas assinalar uma possibilidade do "certo" e do duvidoso para um contexto determinado. Para tanto, deve exercitar sua razão, perscrutando os labirintos de seu saber, a fim de despojar as mensagens de sua roupagem irônica, revelando-as, colocando-as, pois, à vista.

Vimos que o desafio proposto ao sujeito pelo riso, pela ironia e pela paródia está muito próximo da provocação com que somos confrontados pela própria arte - no caso, a literária. Logo, a admiração e a surpresa - sensações comuns àquele que se depara com as categorias aqui estudadas e que as decodifica - estão relacionadas intimamente com a literatura, sobretudo no que se refere às funções estética e catártica, inerentes à arte de um modo geral.

Pensando nisso, de modo semelhante ao que se dá com a literatura, os discursos investigados ao longo da presente pesquisa propiciam ao sujeito - quando descobertos - a experiência do prazer estético e da purificação ou catarse. Conforme comentamos no capítulo 5 , é pertinente concluir, após tais considerações, que a paródia, a ironia e o riso podem ser pensados como "micro-mímesis" ou "microrrepresentações" inseridas na "mímesis-maior", que seria a própria obra literária.

A literatura - representada em nosso trabalho pelas categorias do riso, da paródia e da ironia - desperta no sujeito o desejo e a possibilidade de transcender a sua realidade previsível e mergulhar no impensado, no imprevisto. Assim, por meio da razão - condição necessária para todo esse processo - o indivíduo é estimulado a lançar um olhar mais genuíno e espontâneo para a realidade, tornando factível a ideia de alargar o seu saber. 
Portanto, essas categorias de linguagem tão complexas e fascinadoras facilitam o contato do ser humano consigo mesmo: com seu saber e, ainda, com seu não saber. São discursos que perturbam o sujeito, uma vez que o incitam a lançar um olhar atento sobre si mesmo, em busca de seu repertório. E isso mesmo nas ocasiões em que esbarramos em nossa limitação racional e não conseguimos compreender os sinuosos caminhos da ironia. Ainda quando engolfados por suas refrações traiçoeiras, somos capazes de chegar à maior das verdades da existência, que é a necessidade de alargamento do saber.

Logo, mesmo que a ironia, a paródia ou o riso não surtam o efeito desejado por seus primeiros criadores, o convite para desvendá-los perpetua-se e, com ele, o ensejo de ampliação da percepção crítica. Tal projeção não é utópica, uma vez que, tentando desmascarar os discursos marcados pela ironia, paródia ou riso, desmascaramos, ao que parece, a nós mesmos. 



\section{REFERÊNCIAS BIBLIOGRÁFICAS}

AGUIAR E SILVA, V. M. de. Teoria da literatura. Coimbra: Almedina, 1979.

ALBERTI, V. O riso e o risivel na história do pensamento. Rio de Janeiro: Jorge Zahar; Ed. FGV, 1999.

ALMEIDA, M. A. de. Memórias de um sargento de milícias. São Paulo: Ateliê, 2000.

ALVES, M. da P. C. O cavaleiro inexistente e o homem sem sombra - ou de quando não se vê a imagem no espelho. Mirabilia. Revista Eletrônica de História Antiga e Medieval, 3, 2003.

ANDERSEN, H. C. A sombra. In: Mar de histórias: antologia do conto mundial III: Romantismo. Aurélio Buarque de Holanda Ferreira e Paulo Rónai (Org.). 2.ed. rev. e aum. Rio de Janeiro: Nova Fronteira, 1980.

ARAGÃO, M. L. P. de. A paródia em A força do destino. Revista Tempo Brasileiro (Rio de Janeiro), n.62, p.18-28, jul.-set. 1980.

O romantismo e o gênero romanesco. Revista Tempo Brasileiro (Rio de Janeiro), p.116-28, 1984.

ARENBERG, C. R. The double as an initiation rite: a study of Chamisso, Hoffmann, Poe and Dostoievsky. Washington, 1979. Diss., Department of Comparative Litterature, Washington University. 
ARGENOT, M.; BESSIÈRE, J.; FOKKEMA, D.; KUSHNER, E. Teoria literária: problemas e perspectivas. Trad. Ana Luísa Faria e Miguel Serras Pereira. Lisboa: Dom Quixote, 1995. ARISTÓTELES. Arte retórica e arte poética. Trad. A. P. de Carvalho. Introdução e notas J. Voilquin e J. Capelle. Estudo introdutivo G. Telles Jr. Rio de Janeiro: Edições de Ouro, [19--].

. O homem de gênio e a melancolia: o problema XXX. Trad. grego, apresent. e notas Jackie Pigeaud; trad. Alexei Bueno. Rio de Janeiro: Lacerda, 1998.

; HORÁCIO; LONGINO. A poética clássica. Trad. Jaime Bruna. São Paulo: Cultrix, 1997.

ASSIS, M. de. Teoria do medalhão. In: Contos escolhidos. São Paulo: Martin Claret, 2002.

O espelho. In: Contos escolhidos. São Paulo: Martin Claret, 2002.

BAKHTIN, M. Problemas da poética de Dostoievski. Rio de Janeiro: Forense Universitária, 1981.

. Questões de literatura e estética. São Paulo: Editora UNESP/ Hucitec, 1988.

BARBOSA, J. A. A leitura do intervalo. São Paulo: Iluminuras, 1990.

BARROS, D. L. P. Teoria semiótica do texto. São Paulo: Ática, 1999.

; FIORIN, J. L. (Org.). Paródia e dialogismo. In: Dialogismo, polifonia e intertextualidades: em torno de Bakhtin. São Paulo: Edusp, 1994. (Ensaios de Cultura 7).

BARTH, J. Pos-modernismo revisitado. El Paseante, Madri, n.14, p.92-7, 1990.

. The literature of exhaustion. The Atlantic, Boston, v.220, p.29-34, 1967.

BARTHES, R. O rumor da língua. Lisboa: Edições 70, 1987.

BASTIDE, R. Contos e novelas: Voltaire. Trad. Mário Quintana. São Paulo: Globo, 2005.

BENJAMIN, W. O narrador. In:__. Magia e técnica, arte e política. Trad. S. Rouanet. São Paulo: Brasiliense, 1985. (Obras Escolhidas, 1). 
BERARDINELLI, C. Pela mão do narrador. In: CANIATO, B. J. (Coord. e Ed.). Abrindo caminhos: Homenagem a Maria Aparecida Santili. São Paulo: Coleção Via Atlântica, 2002.

BERGSON, H. O riso. Trad. Ivone Castilho Benedetti. São Paulo: Martins Fontes, 2001.

BERTRAND, D. A enunciação em semiótica. In: Essais de Semiotique Litteraire. Trad. Grupo Casa/UNESP. Texto não publicado. BITTENCOURT, G. N. da S. (Org.). Literatura comparada: teoria e prática. Porto Alegre: Sagra; DC Luzzatto, 1996.

BORNHEIM, G. Filosofia do romantismo. In: GUINSBURG, J. (Ed.). O romantismo. 2.ed. São Paulo: Perspectiva, p.75-111, 1985.

BRAIT, B. A personagem. São Paulo: Ática, 1985. (Série Princípios).

. Ironia em perspectiva polifônica. São Paulo: Editora da Unicamp, 1996.

BRAVO, N. F. Duplo. In: BRUNEL, P. (Org.). Dicionário de mitos literários. Rio de Janeiro: José Olympio.

BUESCU, H. C. (Coord.). Dicionário do romantismo literário português. Lisboa: Caminho,1997.

BUTLER et al. Filosofia moral britânica: textos do século XVIII. v.I. Trad. Álvaro Cabral. Campinas: Editora da Unicamp, 1996.

CALVINO, I. O cavaleiro inexistente. Trad. Nilson Moulin. São Paulo: Companhia das Letras, 2005.

CANDIDO, A. A educação pela noite e outros ensaios. 3.ed. São Paulo: Ática, 2000.

CARPEAUX, O. M. Prosa e ficção do romantismo. In: GUINSBURG, J. (Ed.). O romantismo. 2.ed. São Paulo: Perspectiva, p.157-66, 1985.

CASTELO BRANCO, C. Coração, cabeça e estômago. 2.ed. Lisboa: Europa-América, s.d.

COELHO, J. P. Introdução ao estudo da novela camiliana. Coimbra, 1946.

. Coração, cabeça e estômago: uma estética da ambiguidade. In: A letra e o leitor. 2.ed. Lisboa: Moraes, 1977. 
COLLINI, S. (Dir.). Interpretação e sobreinterpretação. Trad. Miguel Serras Pereira. Lisboa: Presença, 1993.

COMPAGNON, A. O demônio da teoria: literatura e senso comum. Trad. Cleonice Paes Barreto Mourão, Consuelo Fortes Santiago. Belo Horizonte: Editora da UFMG, 2001.

COSTA, L. M. da. A poética de Aristóteles: mimese e verossimilhança. São Paulo: Ática, 1992.

COUTINHO, A. A literatura no Brasil. Era Romântica. São Paulo: Global, 2002.

DAL FARRA, M. L. O narrador ensimesmado: o foco narrativo em Vergílio Ferreira. São Paulo: Ática, 1978.

DERRIDA, J. A escritura e a diferença. São Paulo: Perspectiva, 1971.

DIAS, A. M. (Org.). O resgate da dissonância: sátira e projeto literário brasileiro. Rio de Janeiro: Antares; Inelivro, 1981.

D’ONÓfRIO, S. Teoria do texto. São Paulo: Ática, 1995.

DOSTOIEVSKI, F. M. O duplo. In: Obra completa. v.1. 1963.

DUARTE, L. P. Ironia, humor e fingimento literário. Resultado de pesquisa - ironia e humor em literatura. Belo Horizonte, 1994.

ECO, U. Seis passeios pelos bosques da ficção. Trad. Hildegard Feist. São Paulo: Companhia das Letras, 1994.

. Entre a mentira e a ironia. Trad. Eliana Aguiar. Rio de Janeiro: Record, 2006.

FERNANDES, R. C. O narrador do romance. Rio de Janeiro: Sette Letras, 1996.

FERRAZ, M. de L. A. Ironia romântica. In: Dicionário do romantismo literário português. Coord. Helena Carvalhão Buescu. Lisboa: Caminho, 1997.

FILHO, O. J. de O. Carnaval no convento: intertextualidade e paródia em José Saramago. São Paulo: Editora UNESP, 1993.

FIORIN, J. L. As astúcias da enunciação: as categorias de pessoa, espaço e tempo. São Paulo: Ática, 2001.

FOUCAULT, M. O que é um autor? Porto: Vega Passagens, 2000.

FRIEDMAN, N. O ponto de vista na ficção: o desenvolvimento de um conceito crítico. Trad. Fábio Fonseca de Melo. Revista USP (São Paulo), n.53, p.166-82, mar.-mai. 2002. 
FRYE, N. Crítica histórica: teoria dos modos. In: . Anatomia da crítica. São Paulo: Cultrix, 1973.

FUSILLO, M. Ripensando la critica tematica: l'identità sdoppiata. Compar(a)Ison. v.1, p.231-61, 1996.

GAGNEBIN, J. M. Do conceito de mímesis no pensamento de Adorno e Benjamin. In: Sete aulas sobre linguagem, memória e história. Rio de Janeiro: Imago, 1997.

GARRETT, A. O arco de Sant'Ana. Rio de Janeiro: Edições de Ouro, s.d.

GENETTE, G. Discurso da narrativa. Trad. Fernando C. Martins. Lisboa: Vega, s.d.

GREGGIO, A. J. O riso e a ironia: a leitura da história em $O$ nome da rosa. Araraquara, 2007. Dissertação (mestrado) - FCL da Universidade Estadual Paulista.

GUELFI, M. L. F. Narciso na sala de espelhos: Roberto Drummond e as perspectivas pós-modernas na ficção. Rio de Janeiro, 1994. Tese (doutorado em Letras) - PUC.

GUINSBURG, J. O romantismo. São Paulo: Perspectiva, 2002.

HARVEY, D. Condição pós-moderna. São Paulo: Loyola, 2001.

HAYMAN, D. Um passo além de Bakthine: por uma mecânica dos modos. Revista Tempo Brasileiro (Rio de Janeiro), n.62, p.29-52, jul.-set. 1980.

HAUSER, A. O romantismo alemão e da Europa ocidental. In: . História social da literatura e da arte. Trad. Walter H. Geenen. São Paulo: Mestre Jou, v.2, p.817-77, s.d.

HEGEL, G. W. F. Curso de estética: o sistema das artes. Trad. Álvaro Ribeiro. São Paulo: Martins Fontes, 1997.

HELENA, L. A contra-ideologia da seriedade: antropofagia e cultura brasileira. Revista Tempo Brasileiro (Rio de Janeiro), n.62, p.71-88, jul.-set. 1980.

HERCULANO, A. A Dama pé-de-cabra. In: Lendas e narrativas.

HOBBES, T. Leviatã ou matéria, forma e poder de um Estado eclesiástico e civil. Trad. João Paulo Monteiro e Maria Beatriz Nizza da Silva. 2.ed. São Paulo: Abril Cultural, 1979. 
HUBERMAN, L. História da riqueza do homem. Trad. Waltensir Dutra. 21.ed. Rio de Janeiro: LTC, 1986.

HUGO, V. Do grotesco e do sublime, tradução do prefácio de Cromwel. São Paulo: Perspectiva, 2004.

HUGUES, F. O espaço estético entre a mímesis e a expressão. In: DUARTE, R.; FIGUEIREDO, V. (Org.). Mímesis e expressão. Belo Horizonte: Editora da UFMG, 2001.

HUTCHEON, L. Uma teoria da paródia. Lisboa: Edições 70, 1985. . Poética do pós-modernismo: história, teoria, ficção. Trad. Ricardo Cruz. Rio de Janeiro: Imago, 1991.

. Teoria e política da ironia. Trad. Julio Jeha. Belo Horizonte: Editora da UFMG, 2000.

IANONE, C. A. A persuasão na novela passional camiliana. Brasília: Thesaurus, 1994.

ISER, W. O ato da leitura: uma teoria do efeito estético 2. Trad. Johannes Kretschmer. São Paulo: Editora 34, 1999.

JAUSS, H. R. Tradição literária e consciência atual da modernidade. In: OLINTO, H. K. (Org.). Histórias de literatura: as novas teorias alemãs. São Paulo: Ática, 1996.

JENNY, L. et al. Intertextualidades. Coimbra: Almedina, 1979.

JOZEF, B. O espaço da paródia, o problema da intertextualidade e a carnavalização. Revista Tempo Brasileiro (Rio de Janeiro), n.62, p.53-70, jul.-set. 1980.

KANT, I. Crítica da faculdade do juízo. Trad. Valério Rohden e António Marques. 2.ed. Rio de Janeiro: Forense Universitária, 2005.

KIERKEGAARD, S. The concept of irony. Trad. Lee M. Capel. Bloomington: Indiana University Press, 1965.

KOTHE, F. R. Paródia e cia. Revista Tempo Brasileiro (Rio de Janeiro), n.62, p.97-113, jul.-set. 1980.

KRAUSS, W. Das Doppelgängermotiv. Der Romantik, Studien zum Idealismus, Germanische Studien, Heft 99. Berlim, 1930.

LACOUE-LABARTHE, P. A vera semelhança. In: DUARTE, R.; FIGUEIREDO, V. (Org.). Mímesis e expressão. Belo Horizonte: Editora da UFMG, 2001. 
LEITE, L. C. M. O foco narrativo. São Paulo: Ática, 1993.

LIMA, L. C. O controle do imaginário: razão e imaginação nos tempos modernos. Rio de Janeiro: Forense Universitária, 1989. . Vida e mimesis. Rio de Janeiro: Editora 34, 1995.

Mímesis: desafio ao pensamento. Rio de Janeiro: Civilização Brasileira, 2000.

- Máscaras da mímesis: a obra de Luiz Costa Lima. Org. Hans Ulrich Gumbrecht, João Cezar de Castro Rocha. Rio de Janeiro: Record, 1999.

LYOTARD, J. O pós-moderno. Trad. R. Corrêa Barbosa. 4.ed. Rio de Janeiro: José Olympio, 1993.

MAIA, M. H. P. As formas da paródia em $\mathrm{O}$ ano da morte de Ricardo Reis de José Saramago. Araraquara, 1999. Dissertação (mestrado) - FCL da Universidade Estadual Paulista.

MARTINS, M. O riso, o sorriso e a paródia na literatura portuguesa de Quatrocentos. Portugal: Instituto de Cultura Portuguesa, 1978.

MINOIS, G. História do riso e do escárnio. Trad. Maria Helena O. Ortiz Assumpção. São Paulo: Editora UNESP, 2003.

MOISÉS, M. A literatura portuguesa. 29.ed. São Paulo: Cultrix, 1999.

MUCHEMBLED, R. Uma história do diabo: séculos XII-XX. Trad. Maria Helena Kühner. Rio de Janeiro: Bom Texto, 2001.

MUECKE, D. C. A ironia e o irônico. Trad. Geraldo Gerson de Souza. São Paulo: Perspectiva, 1995. (Debates, 250).

NESTROVSKI, A. Ironias da modernidade. São Paulo: Ática, 1996.

NIETZSCHE, F. Além do bem e do mal: prelúdio a uma filosofia do futuro. Trad., notas e posfácio Paulo Cesar de Souza. São Paulo: Companhia das Letras, 2005.

NUNES, B. A visão romântica. In: GUINSBURG, J. (Ed.). O romantismo. 2.ed. São Paulo: Perspectiva, p.51-74, 1985.

ORLANDI, E. P. Interpretação, autoria, leitura e efeitos do trabalho simbólico. 2.ed. Petrópolis: Vozes, 1998.

PAIVA, M. H. N. Contribuição para uma estilística da ironia. Lisboa: Publicações do Centro de Estudos Filosóficos, 1991.

PENA, M. O noviço. Rio de Janeiro: Ediouro, 2003. 
PEREIRA, L. M. Ecos românticos, veleidades realistas. In:

Prosa de ficção (de 1870 a 1920). 2.ed. rev. Rio de Janeiro: José Olympio, p.29-50, 1957.

POUILLON. O tempo no romance. Trad. Heloysa de Lima Dantas. São Paulo: Cultrix; Edusp, 1974.

PROPP, V. Comicidade e riso. São Paulo: Ática, 1992.

REIS, C.; LOPES, A. C. Dicionário de teoria da narrativa. São Paulo: Ática, 1988. (Fundamentos, 29).

REIS, C. Estatuto e perspectivas do narrador na ficção de Eça de Queirós. Coimbra: Almedina, 1975.

REUTER, Y. Introdução à análise do romance. São Paulo: Martins Fontes, 1996.

RIBEIRO, R. J. A marca do Leviatã. São Paulo: Ática, 1978.

RODRIGUES, S. C. Um diálogo no espelho. Revista Tempo Brasileiro (Rio de Janeiro), n.62, p.114-27, jul.-set. 1980.

ROSENFELD, A. Texto/contexto. 3.ed. São Paulo: Perspectiva, 1976.

ROUANET, S. P. Riso e melancolia: a forma shandiana em Sterne, Diderot, Xavier de Maistre, Almeida Garrett e Machado de Assis. São Paulo: Companhia das Letras, 2007.

SANTILLI, M. A. Arte e representação da realidade no romance português contemporâneo. São Paulo: Quíron, 1979.

SARAIVA, A. J.; LOPES, O. História da literatura portuguesa. Porto: Porto Ed., s.d.

SARAMAGO, J. O homem duplicado. São Paulo: Companhia das Letras, 2002.

SARTRE, J.-P. et al. Romance e realidade. Lisboa: D. Quixote, 1969.

SCHNAIDERMAN, B. Paródia e mundo do riso. Tempo Brasileiro (Rio de Janeiro), n.62, p.89-96, jul.-set. 1980.

SCHOPENHAUER, A. O mundo como vontade e como representação. t.1. Trad., apresent., notas e índices Jair Barboza. São Paulo: Editora UNESP, 2005.

SCHWARZ, R. O mano capeta do liberalismo ("O sósia"). In: . A sereia e o desconfiado: ensaios críticos. 2.ed. Rio de Ja- 
neiro: Paz e Terra, p.81-96, 1981. (Coleção Literatura e Teoria Literária, 37).

SIEBERS, T. Figurative language and the fantastic. In: The romantic fantastic. Ithaca; Londres: Cornell University Press, p.104-21, 1984.

Madness, magic, and the romantic self. In: . The romantic fantastic. Ithaca; Londres: Cornell University Press, p.167-89, 1984.

SILVA, A. M. Z. da. Humor e sátira: a outra face de Edgar Alan Poe. Araraquara, 2006. Tese - FCL da Universidade Estadual Paulista.

STAROBINSKI, J. Ironie et mélancholie I. Critique. v.227, p.291 -308, abr. 1966.

. Ironie et mélancholie II. Critique. v.228, p.438-57, mai. 1966.

TACCA, O. O narrador. In: As vozes do romance. Coimbra: Almedina, 1983.

VILLAÇA, N. Paradoxos do pós-moderno. Rio de Janeiro: Editora da UFRJ, 1996.

VOLOBUEF, K. Frestas e arestas: a prosa de ficção do romantismo na Alemanha e no Brasil. São Paulo: Editora UNESP, 1999. Romantismo na Alemanha e no Brasil: um estudo da prosa de ficção. São Paulo, 1996. Tese (doutorado em Letras) - Faculdade de Filosofia, Letras e Ciências Humanas, Universidade de São Paulo.

WELLEK, R. et al. Teoria da literatura. Lisboa: Europa-América, 5.ed., s.d.

WAUGH, P. Metafiction. Londres: Routledge, 1990.

WEINRICH, H. Le temps. Le récit et le commentaire. Trad. para o francês de Michèle Lacoste. Paris: Collection Poètique, 1989. 
SOBRE O LIVRO

Formato: $14 \times 21 \mathrm{~cm}$

Mancha: 23, $7 \times 42,10$ paicas

Tipologia: Horley Old Style 10,5/14

2009

EQUIPE DE REALIZAÇÃO

Coordenação Geral

Tulio Kawata 
\begin{tabular}{l} 
CULTURA \\
ACADÊMICA \\
\hline$\varepsilon d i t o k a$
\end{tabular} 